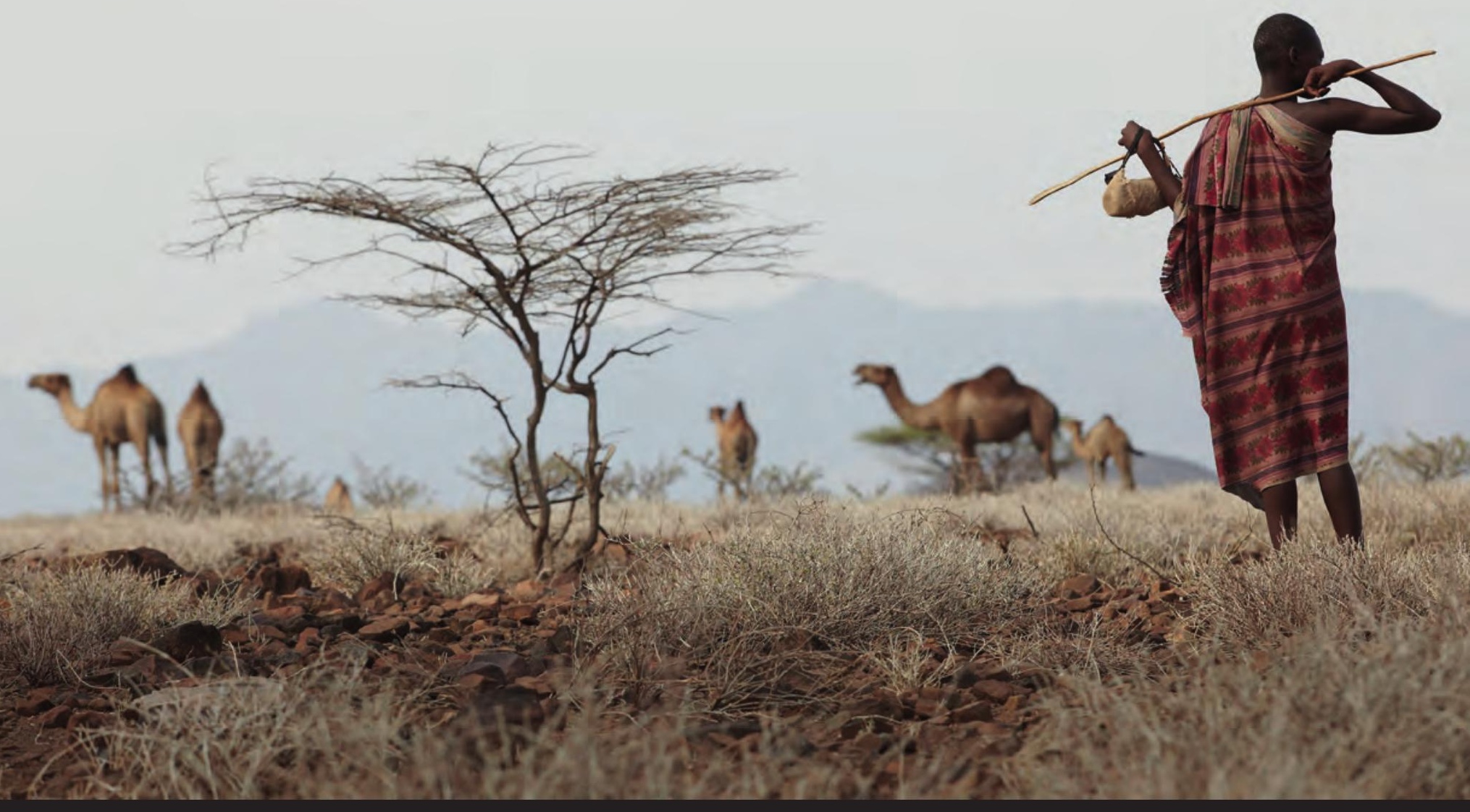

\title{
THE IMPACT OF IN-KIND FOOD ASSISTANCE ON PASTORALIST LIVELIHOODS IN HUMANITARIAN CRISES
}




\begin{abstract}
About this evidence synthesis
This is an independent evidence synthesis commissioned by the Humanitarian Evidence Programme - a partnership between Oxfam GB and Feinstein International Center at the Friedman School of Nutrition Science and Policy, Tufts University. It was funded by aid from the United Kingdom government through the Humanitarian Innovation and Evidence Programme at the Department for International Development. The views and opinions expressed herein are those of the authors and do not necessarily represent those of Oxfam, the Feinstein International Center or the UK government.
\end{abstract}

\title{
About the research team
}

This report was written by:

- Karol Czuba, PhD Candidate, Department of Political Science, University of Toronto (Principal Investigator) - corresponding author, karol.czuba@mail.utoronto.ca

- Tyler J. O'Neill, Clinician Scientist, Dalla Lana School of Public Health, University of Toronto

- Ana Patricia Ayala, Instruction and Faculty Liaison Librarian, Gerstein Library, University of Toronto.

The initial database and website searches took place during June 2016.

\section{Citation}

Czuba, K., O'Neill, T.J. and Ayala, A.P. (2017). The impact of food assistance on pastoralist livelihoods in humanitarian crises: An evidence synthesis. Humanitarian Evidence Programme. Oxford: Oxfam GB.

\section{Acknowledgments}

The authors would like to thank the HEP, Oxfam GB, Feinstein International Center and DFID for the opportunity and funding to conduct this research project. Special thanks go to Eleanor Ott at Oxfam and Roxanne Krystalli at Feinstein for their support over the course of the project.

\section{Series editors}

These report forms part of a series of humanitarian evidence syntheses and systematic reviews covering child protection, market support, mental health, nutrition, pastoralist livelihoods, shelter, urban contexts, and water, sanitation and hygiene. The reports and corresponding protocols can be found at:

- https://www.gov.uk/dfid-research-outputs

- http://fic.tufts.edu/research-item/the-humanitarian-evidence-program/

- http://policy-practice.oxfam.org.uk/our-work/humanitarian/humanitarian-evidenceprogramme.

The series editors are: Roxanne Krystalli, Eleanor Ott and Lisa Walmsley.

\section{Photo credit}

Andy Hall/Oxfam 2011.

\section{(c) Copyright Oxfam GB 2017}

This publication is subject to copyright but the text may be used free of charge for the purposes of advocacy, campaigning, education and research, provided that the source is acknowledged in full. The copyright holder requests that all such use be registered with them for impact assessment purposes. For copying in any other circumstances, or for re-use in other publications, or for translation or adaptation, permission must be secured and a fee may be charged. Email: Iwalmsley1@ght.oxfam.org 


\section{CONTENTS}

0 EXECUTIVE SUMMARY I

1 INTRODUCTION 1

1.1 Background 1

1.2 Rationale and purpose 2

1.3 Research questions 3

2 METHODOLOGY 6

2.1 Protocol development 6

2.2 Implementation of the search strategy 6

$\begin{array}{lll}2.3 & \text { Document screening } & 7\end{array}$

2.4 Evidence assessment 8

2.5 Data extraction and evidence synthesis 9

3 RESULTS 10

$\begin{array}{lll}3.1 & \text { Summary of reviewed publications } & 10\end{array}$

$\begin{array}{ll}3.2 & \text { Included publications } \\ 3.3 & \end{array}$

$\begin{array}{ll}\text { 3.3 Outcomes reported by included publications } & 12\end{array}$

$\begin{array}{lll}3.4 & \text { Assessment of the strength of evidence and causal claims } & 12\end{array}$

$\begin{array}{lll}3.5 & \text { Narrative synthesis of results } & 13\end{array}$

4 CONCLUSION 19

$\begin{array}{lll}4.1 & \text { Limitations } & 20\end{array}$

APPENDIX 1: DATABASE SEARCH STRATEGY STRINGS 30

APPENDIX 2: INCLUDED PUBLICATIONS AND REPORTED INTERVENTIONS AND $\begin{array}{ll}\text { IMPACTS } & 40\end{array}$

REFERENCES

Included publications $\quad 42$

Other 43 


\section{EXECUTIVE SUMMARY}

This evidence synthesis, commissioned by the Humanitarian Evidence Programme (HEP) and carried out by a research team from the University of Toronto, represents the first ever attempt to identify, synthesize and evaluate existing evidence on both the short- and longterm impacts of in-kind food assistance on pastoralist populations and their livelihoods in humanitarian crises. ${ }^{1}$

The synthesis is based on a rigorous methodology and follows an adapted scoping study approach. It aims to:

- verify the quality of existing evidence relating to this key type of humanitarian intervention

- help researchers identify the strengths and weaknesses in such evidence, and thus to recognize potential improvements and opportunities in future research

- assist practitioners and policy makers in evaluating the impact of past choices and investments.

\section{Definitions}

This review uses the term 'pastoralists' to refer to people who depend on livestock for a significant proportion of their food and income, including those who might also cultivate crops and/or carry out other economic activities.

The term 'livelihoods' is used to refer to the 'capabilities, assets (including material and social resources) and activities required for a means of living' (Scoones, 1998: 5). The review covers a wide range of livelihood systems, based on a list derived from Hesse and MacGregor (2006: 5).

For further detail on the definitions used, see the box 'Definition of common terms included in this review' on pp.1-2 of the full report.

\section{What are the impacts of in-kind food assistance in humanitarian crises on pastoralists and their livelihoods?}

The research team looked at 12 key questions that mapped on to six thematic outcome areas (see Figure 0.1).

\footnotetext{
${ }^{1}$ The Humanitarian Evidence Programme (HEP) is a partnership between Oxfam GB and the Feinstein International Center at Tufts University. It is funded by the UK government's Department for International Development (DFID) through the Humanitarian Innovation and Evidence Programme (HIEP).
} 
Figure 0.1: The impact of in-kind food assistance on pastoralists' livelihoods - summary of findings

\begin{tabular}{|c|c|c|c|c|}
\hline $\begin{array}{l}\text { Thematic } \\
\text { outcome }\end{array}$ & $\begin{array}{l}\text { Number of } \\
\text { studies* }\end{array}$ & $\begin{array}{l}\text { Evidence } \\
\text { strength }^{\star *}\end{array}$ & Research question ${ }^{* * *}$ & Findings \\
\hline \multirow[t]{3}{*}{$\begin{array}{l}\text { Changes in } \\
\text { livelihood } \\
\text { strategies and } \\
\text { asset and } \\
\text { income } \\
\text { dynamics }\end{array}$} & \multirow[t]{3}{*}{11} & \multirow[t]{3}{*}{ Medium } & $\begin{array}{l}\text { Q1: In what ways have pastoralist livelihood } \\
\text { strategies changed since } 1967 \text { (and to what } \\
\text { extent have non-pastoralist livelihood strategies } \\
\text { supplanted them)? What is the potential causal } \\
\text { relationship between these changes and food } \\
\text { assistance? }\end{array}$ & $\begin{array}{l}\text { Food assistance can undermine the } \\
\text { livelihood strategies of pastoralists. }\end{array}$ \\
\hline & & & $\begin{array}{l}\text { Q2: In what ways have pastoralist asset } \\
\text { dynamics changed? What is the potential } \\
\text { causal relationship between these changes } \\
\text { and food assistance? }\end{array}$ & $\begin{array}{l}\text { Food assistance can lead to reduced } \\
\text { livestock sales and strengthen herd } \\
\text { growth. }\end{array}$ \\
\hline & & & $\begin{array}{l}\text { Q3: In what ways have income dynamics } \\
\text { changed? What is the potential causal } \\
\text { relationship between these changes and food } \\
\text { assistance? }\end{array}$ & $\begin{array}{l}\text { Food assistance may fill gaps in } \\
\text { pastoralists' incomes. }\end{array}$ \\
\hline Mobility patterns & 9 & Limited & $\begin{array}{l}\text { Q4: In what ways have mobility patterns } \\
\text { changed? What is the potential causal } \\
\text { relationship between these changes and food } \\
\text { assistance? }\end{array}$ & $\begin{array}{l}\text { Food assistance can lead to changes } \\
\text { in pastoralists' mobility patterns, and } \\
\text { especially to sedentarization. }\end{array}$ \\
\hline \multirow[t]{3}{*}{$\begin{array}{l}\text { Access to in- } \\
\text { kind food } \\
\text { assistance }\end{array}$} & \multirow[t]{3}{*}{7} & \multirow[t]{3}{*}{ Limited } & $\begin{array}{l}\text { Q5: What types of in-kind food assistance } \\
\text { interventions have been offered to pastoralist } \\
\text { populations in the context of humanitarian } \\
\text { crises? How have these interventions, the } \\
\text { nature of the strategies, the distribution of food } \\
\text { assistance and its duration changed over time? }\end{array}$ & $\begin{array}{l}\text { Food assistance to pastoralists can be } \\
\text { insufficient and unbalanced. }\end{array}$ \\
\hline & & & $\begin{array}{l}\text { Q6: In what ways do pastoralists use the food } \\
\text { they receive? Do they consume it, or use it as } \\
\text { livestock feed or as a commodity to sell or } \\
\text { barter? }\end{array}$ & $\begin{array}{l}\text { Four publications claim that food } \\
\text { assistance can lead to dependency, } \\
\text { but there is no relevant empirical } \\
\text { evidence. }\end{array}$ \\
\hline & & & $\begin{array}{l}\text { Q7: In what ways has access to food and non- } \\
\text { food items in pastoralist areas changed, } \\
\text { including in relation to markets? What is the } \\
\text { potential causal relationship between these } \\
\text { changes and food assistance? }\end{array}$ & $\begin{array}{l}\text { According to one publication, food } \\
\text { assistance can lead to an increase in } \\
\text { alcohol production. In some cases } \\
\text { food assistance targeting has been } \\
\text { controversial where pastoralists have } \\
\text { perceived issues of unfairness, } \\
\text { unequal distribution and elite capture. }\end{array}$ \\
\hline \multirow{2}{*}{$\begin{array}{l}\text { Household- and } \\
\text { individual-level } \\
\text { socio- } \\
\text { demographic } \\
\text { factors }\end{array}$} & \multirow[t]{2}{*}{7} & \multirow[t]{2}{*}{ Limited } & $\begin{array}{l}\text { Q8: What household-level shifts have taken } \\
\text { place among pastoralist populations? What is } \\
\text { the potential causal relationship between these } \\
\text { changes and food assistance? }\end{array}$ & $\begin{array}{l}\text { Food assistance can encourage } \\
\text { pastoralist women to seek alternative } \\
\text { livelihood strategies. }\end{array}$ \\
\hline & & & $\begin{array}{l}\text { Q9: What individual-level shifts have taken } \\
\text { place among pastoralist populations? What is } \\
\text { the potential causal relationship between these } \\
\text { changes and food assistance? }\end{array}$ & $\begin{array}{l}\text { According to most publications, food } \\
\text { assistance leads to decreased } \\
\text { malnutrition. Others report, however, } \\
\text { that food assistance can have negative } \\
\text { impacts on recipients' health } \\
\text { outcomes. }\end{array}$ \\
\hline $\begin{array}{l}\text { Social relations } \\
\text { and governance }\end{array}$ & 4 & Limited & $\begin{array}{l}\text { Q10: What shifts have taken place in the social } \\
\text { relations of pastoralist populations, including in } \\
\text { relation to social support networks? What is the } \\
\text { potential causal relationship between these } \\
\text { changes and food assistance? }\end{array}$ & $\begin{array}{l}\text { Food assistance can both strengthen } \\
\text { relations within existing social } \\
\text { networks and contribute to the } \\
\text { emergence of new political leaders } \\
\text { (and displacement of their } \\
\text { predecessors). }\end{array}$ \\
\hline Security & 4 & $\begin{array}{l}\text { Not } \\
\text { applicable }\end{array}$ & $\begin{array}{l}\text { Q11: In what ways have the security conditions } \\
\text { within which pastoralist livelihoods take place } \\
\text { changed? What is the potential causal } \\
\text { relationship between these changes and food } \\
\text { assistance? }\end{array}$ & $\begin{array}{l}\text { The publications do not make a causal } \\
\text { link between food assistance and } \\
\text { security. }\end{array}$ \\
\hline
\end{tabular}

Notes:

* Some publications report more than one outcome and are included in one or more themes.

** Evidence strength: medium = moderate-quality studies, medium-size evidence body, moderate level of consistency; limited = moderate-to-low-quality studies, medium-size evidence body, low levels of consistency.

*** The evidence synthesis addresses 12 research questions (Qs). Evidence on 11 of them is presented in Figure 0.1 . A further question (Q12) - 'What are the populations and regions affected by food assistance interventions targeting pastoralists? What are the commonalities and variations between these populations and regions?' - is considered in the section below on the state of the evidence. 


\section{What evidence was eligible for synthesis?}

Of the 23,424 publications identified in an initial search of academic databases, and an additional 1,442 from grey literature sources, 24 were deemed suitable for synthesis following screening and quality appraisal. These publications:

- are all in English (the search strategy was limited to English and French)

- were all published between 1983 and 2015 (and mainly since 2000)

- are mainly primary studies $(n=20)$

- include studies that used qualitative methods $(n=13)$, quantitative methods $(n=6)$ and mixed methods $(n=5)$.

Collectively, the selected 24 publications report food assistance interventions during or after humanitarian crises that:

- took place between 1967 and 2012

- lasted between one and 20 years

- were predominantly drought-related $(n=21)$ but have other identified causal factors, including conflict $(n=3)$, famine $(n=4)$, flood $(n=2)$ and disease $(n=1)$

- took place primarily in countries in the East and Horn of Africa, with the remainder in Algeria, Niger and Mongolia

- targeted Mongolian herders in Asia $(n=2)$ and a range of African pastoralist ethnic groups, including the Beja, Gabbra, Oromo, Pokot, Rashaida, Saharawis, Somalis and Turkana

- targeted populations of between 6,000 and an estimated 20 million people

- involved unconditional provision of food in-kind $(n=23)$ or in exchange for assets (livestock) and work ( $n=2)$; nine publications fail to identify the modality of food assistance provision

- were carried out by non-governmental organizations (NGOs) $(n=7)$, United Nations agencies $(n=5)$, national governments $(n=4)$, religious bodies $(n=2)$ or a combination of these $(n=6)$.

\section{What is the state of the evidence?}

Reported evidence indicates that:

- Food assistance can, in some cases, achieve its primary goal of addressing food insecurity. Evidence from Kenya and Somalia indicates that some food assistance interventions have led to a decrease in rates of malnutrition. On the other hand, provision of food assistance in Ethiopia and Sudan is claimed to have had negative impacts on health outcomes. The strength of evidence relating to this theme is limited. Provision of food assistance can contribute - and, as evidence from Kenya and Sudan indicates, has contributed - to the erosion of pastoralist livelihoods. However, interventions in Kenya seem to have enabled some pastoralists to hold on to their assets, including livestock, and to have supported their incomes. The strength of evidence relating to this theme is medium.

- There is fairly uniform - but, because of limited strength of evidence, not necessarily reliable - evidence from Kenya and Sudan that the provision of food assistance leads to changes in pastoralists' mobility patterns, especially sedentarization. The strength of evidence relating to this theme is limited. Claims that food assistance can lead to dependency are relatively widespread, but there is no identified empirical evidence of a causal relationship. On the other hand, food assistance can have other detrimental effects: according to one publication, provision of food assistance in Kenya has led to an increase in alcoholism. The strength of evidence relating to this theme is limited.

- In some reported cases - in Kenya, Mongolia and Sudan - the modes of targeting of food assistance have led to internal controversy (related to unequal distribution, perceived unfairness and elite capture) within pastoralist communities. Elsewhere, they have effectively encouraged the emergence of new political leaders who have sought to channel assistance to their clients and, by extension, have restricted some intended 
beneficiaries' access to food; evidence from Kenya and Sudan indicates the existence of an association between food assistance and the creation of new power structures.

Conversely, one publication reports that an intervention in Kenya encouraged sharing of food and thereby strengthened existing social networks. The strength of evidence relating to these themes is limited. There is no evidence in the included publications of the existence of a causal link between the provision of food assistance and the security situation in areas inhabited by its beneficiaries.

This review uses guidelines developed by the UK Department for International Development (DFID) and published in the Assessing the Strength of Evidence note (DFID, 2014) to evaluate the strength of evidence reported in the included publications. Based on their conformity with the criteria defined by the note, this review does not consider the strength of evidence reported in any of the publications to be high. The strength of evidence in 13 publications is classified as moderate, while the remaining 11 publications report evidence of low strength. Causal inferences made in included publications are especially problematic. In most publications, the method of analysis is not reported; causal claims are not supported by evidence and are reported as the authors' impressions of observed events or outcomes. While the research team has chosen not to exclude publications on the grounds of the strength of reported evidence, claims made in most of the included publications are not reliable.

Because of the lack of high-strength evidence, the assessment of the impacts of food assistance on pastoralists contained in this review is necessarily inconclusive. While the difficulty of conducting research in the context of humanitarian crises should be recognized, the inadequate quality of the included publications makes it impossible to reliably evaluate the impacts of common types of humanitarian intervention targeting some of the world's most vulnerable populations. As such, it can prevent identification of potential harmful impacts and other deficiencies of the provision of food assistance to pastoralist populations.

The findings of this review highlight, therefore, the necessity of future multidisciplinary research and evaluation that can make valid inferences about the causal relationships between food assistance and various aspects of pastoralist livelihoods. Such high-quality research could be both qualitative and quantitative, but it should include experimental and prospective cohort studies, as well as retrospective cohort designs which rely on validated methods. New research should also disaggregate outcomes by age, gender, and mobility patterns. 
Pastoralists rely on coping and adaptation strategies that have historically allowed them to achieve high levels of productivity, manage the hazards and unpredictability of life in the marginal areas that they occupy and moderate the impacts of shocks (Butt et al., 2009; Hesse and Pattison, 2013; Morton, 2006). Despite the unique suitability of these strategies to their livelihoods, however, the food security of many pastoralist populations - especially in Africa - has increasingly been threatened. For example, the 2006 drought in East Africa and the Horn of Africa (affecting Djibouti, Eritrea, Ethiopia, Kenya and Somalia) caused severe shortages of food across the pastoralist corridor that contains the largest grouping of pastoralists in the world (Mkutu, 2001). The drought affected a reported 11 million people, including many pastoralists (FAO, n.d.; ODI, 2006). Famine returned to the region in 2011 and 2012; in Somalia, where 80 percent of the population is pastoralist (Central Bank of Somalia, n.d.) and where the food crisis was most acute, an estimated 260,000 people died, another 750,000 were affected and 3.3 million people were in need of immediate life-saving assistance. Altogether, 13 million people were affected by the food security crisis in the Horn of Africa (Maxwell et al., 2014: 5). Similarly, 800,000 people - including many pastoralists faced severe food insecurity and another 800,000 were moderately insecure during the 2005 and 2006 Niger food crisis (Aker, 2008: 7). ${ }^{3}$ While such crises have primarily affected African pastoralists, they have also been reported elsewhere. For example, 8,000 Mongolian pastoralists affected by $d z u d$ (harsh winter conditions) received food assistance in 2010 (Action Against Hunger, 2011).

Crises faced by pastoralists have increased in frequency and intensity in recent decades. Because of climate change, political marginalization, loss of grazing land, restrictions on mobility and other detrimental policies pursued by national governments, some pastoralists are no longer able to overcome them without outside assistance (Markakis, 2004: 4). Such assistance has taken many forms, but nutrition and food security have been the priorities of most humanitarian interventions, which have usually involved direct provision of food in-kind to affected populations.

\section{Definition of common terms included in this review \\ Pastoralism}

Pastoralists are people whose livelihoods rely primarily on livestock keeping and who occupy marginal areas incapable of supporting an exclusively or primarily agriculturalist population. By extension, pastoralism is the mode of production practised by such people. Such a basic definition should not be controversial; many specific aspects of pastoralism are, however, contested.

First, pastoralist societies have developed complex modes of social organization and cultural patterns that are intrinsically integrated with the pastoralist mode of production. In this respect, therefore, pastoralism is not just a livelihood strategy, but a cultural identity and way of life (Markakis, 2004: 4). The erosion of the basis of pastoralist livelihoods in recent decades may imply the decline of pastoralist cultures and societies but, even if they survive, their direct link with the pastoralist mode of production may be weakened. If this is the case, the decline of pastoralism as a set of livelihood strategies does not necessarily mean a corresponding decay of pastoralist culture and society or the disappearance of people who identify themselves as pastoralists. Therefore, inclusion of these non-economic practices radically expands the definition of pastoralism.

Second, the commonly accepted classification of livelihood systems presents a continuity of practices, from 'pure' pastoralism to exclusive reliance on agriculture or urban livelihoods. In this typology (as Krätli et al., 2015 note), differences between livelihood systems are effectively a matter of degree: of mobility (nomadic, seminomadic, transhumant, sedentary), of average rainfall (desert, arid, semi-arid, sub-humid), of interaction with the market economy (subsistence-based, market-driven), of attainment of modernity (traditional, modernizing, modern) and, of course, of dependence on livestock and involvement in agriculture (Ibid.: 15). The temptation that this classification offers is to restrict the definition of the term to 'pure pastoralism', i.e. a form of pastoralist livelihood that is nomadic, subsistence-based, traditional and dependent solely on livestock keeping, and to

\footnotetext{
${ }^{2}$ This Introduction section is based on the review protocol (Czuba and O'Neill, 2016), which considers the issues outlined here in greater detail.

${ }^{3}$ Households or individuals can be classified as facing severe food insecurity if they have large food consumption gaps or have suffered extreme loss of livelihood assets that will lead to such gaps. They can be classified as facing moderate food insecurity if they have food consumption gaps or are only able to meet minimum food needs through accelerated depletion of livelihood assets (Rose, 2012).
} 
develop other labels, such as agropastoralism, to refer to the other degrees. While this results in elegant categorizations, however, the deep connections between modes of production that rely in some way on livestock keeping are concealed.

For this reason, a broad definition of pastoralism is likely to offer a better lens through which to consider the subject of this review. The review follows a definition that incorporates the characteristics common to a wide range of pastoralist livelihood systems and is derived from a list compiled by Hesse and MacGregor (2006: 5). In this definition, pastoralists are people who depend on livestock for a significant proportion of their food and income, although they may also cultivate crops and carry out other economic activities. Their livestock can be raised for both subsistence and market needs, but animals represent more than economic assets. Instead, they constitute cultural, social and spiritual assets that define social identity. Livestock depend on natural pastures, the management of which may require mobility of herds and pastoralists themselves. By extension, pastoralism is the livelihood system of pastoralists.

This broad definition includes a wide range of livelihood systems and intentionally makes no distinction between different 'degrees' of pastoralism, as listed above. It is also likely to capture more food assistance interventions and, therefore, to provide a fuller understanding of the impacts of food assistance on diverse livestock-keeping populations. It is, however, necessary to be mindful that such a broad understanding of pastoralism is not universally accepted and that the use of the term in some sources identified during the search process will either refer exclusively to the pastoralist mode of production or to 'pure pastoralism'. Furthermore, the protocol highlighted the need for the research team to be aware of the possible presence in the searched publications of commonly held biases against pastoralists brought about by their economic and political marginalization (Ibid.: 15).

\section{Livelihoods}

Livelihoods are defined as the 'capabilities, assets (including both material and social resources), and activities required for a means of living' (Scoones, 1998: 5). Therefore, pastoralist livelihoods represent:

- capabilities such as knowledge, skills and training required to raise and properly care for livestock and navigate territories which pastoralists occupy. This includes locating appropriate grazing areas and other sources of food and interacting with other pastoralist and non-pastoralist populations;

- assets such as livestock, access to grazing and agricultural land, tools and social organization conducive to pastoral livelihoods;

- the activities that these capabilities and assets make possible, i.e. livestock keeping and, where applicable, seasonal agricultural production and waged employment.

\section{Food assistance}

Food assistance refers to any direct food or food procurement transfer to food-insecure individuals or households for the purpose of increasing the quality and/or quantity of food consumed or, in some cases, as a form of income transfer. Food assistance can be provided in the context of low food availability or low food access. It can be provided by organizations such as national governments, non-government organizations (NGOs) and international organizations or their specialized agencies. Respondents can receive it on a short-term basis or, in the context of protracted emergencies, for extended periods of time. The most commonly used type of humanitarian assistance to pastoralists has been the direct provision of food in-kind, which can be either short- or long-term and unconditional or tied to assets or work, as in the case of the World Food Programme's Food Assistance for Assets programmes (WFP, n.d.). In addition, recent innovations in food provision in humanitarian settings have involved the use of cash transfers and vouchers (ECHO, 2013; Harvey and Bailey, 2011; Manley et al., 2011; Smith et al., 2011; Doocy and Tappis, 2015). Alternatively, the price of food in an affected area can be subsidized (Levine, 2008: 2). The term 'food assistance' has largely replaced 'food aid' in the language used by the international community (Clay, 2010; Harvey et al., 2010).

\section{Crisis and humanitarian crisis}

A crisis or shock is defined as an event or events that destabilize the livelihoods of a population. A humanitarian crisis is defined as an event or events that pose an exceptional and generalized threat to the health, safety, wellbeing or subsistence of a population. This phenomenon can have either a slow or rapid onset, be acute or chronic, and be either natural in origin (e.g. drought) or man-made (e.g. conflict) (or its causes can be attributable to both natural and man-made factors) (Chi et al., 2015).

Humanitarian crises have affected millions of pastoralists and have led to a range of interventions that have mobilized considerable resources in an attempt to alleviate suffering and improve the viability of pastoral livelihoods. However, evidence on the effects that these interventions have had on pastoralists - particularly the extent to which they have achieved their stated objectives - is, at best, fragmentary. Reported assessments of the effectiveness of interventions that specifically target pastoralists have generally been negative, but the evidence tends to be limited to selective case studies that should not be used to draw general inferences (e.g. Fratkin, 2001; Fratkin et al., 2004; Hesse and Thébaud, 2006; Markakis, 2004). There is a number of more rigorous evidence syntheses that assess humanitarian interventions (e.g. HEP nutrition review, forthcoming; Harvey and Bailey, 2011; Manley et al., 2011; Smith et al., 2011; Doocy and Tappis, 2015; Bellos et al., 2010; London School of Hygiene and Tropical Medicine, 2013; Crumlish and O'Rourke, 2010; HEP mental health review, forthcoming; Spangaro et al., 2013; Vu et al., 2014; HEP child protection 
review, forthcoming; Parkinson, 2009; Yates et al., forthcoming), but they do not specifically consider the impacts of these interventions on pastoralists, whose distinctiveness suggests that the effects of interventions targeting them are likely to differ significantly from other populations. There is, therefore, a great need for systematic evidence of the impacts of humanitarian interventions on pastoralists to inform policy and to suggest a future research or programme monitoring agenda. It is impossible to provide comprehensive evidence of all impacts in the context of a single review. Because the provision of food assistance to populations experiencing high levels of food insecurity has long been the dominant form of relief assistance, it follows that it should be the subject of the first evidence synthesis addressing the impacts of humanitarian interventions on pastoralists.

The purpose of this review is, therefore, to use evidence synthesis methods (specifically the scoping study approach, which uses rigorous and transparent methods to comprehensively identify and analyze all relevant literature pertaining to a research question, but can also address broader topics and a wider range of study designs than a systematic review), to identify, synthesize, evaluate and estimate both the short- and long-term effects that the provision of food assistance in the context of humanitarian crises has had on pastoralists and their livelihoods. The review considers all potential impacts of in-kind food assistance on all pastoralist populations that have been affected by humanitarian emergencies in the period since 1967 (when the Food Aid Convention was negotiated). ${ }^{4}$ Where possible, this investigation includes evaluating the intended impacts of the interventions, i.e. their effectiveness and efficiency in providing food assistance to those in need and the use of food by their beneficiaries for the purposes intended. Equally important is an examination of other, often unintended, effects of the provision of food assistance. The literature on pastoralist societies suggests a number of potential unintended consequences, including long-term dependency on external provision of food (Abbink et al., 2014; Bassi, 2010; Boulton, 2012; Helland, 1998; Levine, 2010), exclusion of the poorest (Bishop and Hilhorst, 2010; Maxwell et al., 2014: 28) and undermining of existing social support networks (Sharp, 1999). Other impacts of food assistance might include shifts in livelihood strategies and mobility patterns (including sedentarization) (Fratkin et al., 2004; Salzman, 1980), new dynamics concerning assets (including sale, acquisition of assets and asset types) and income (Abebe et al., 2008; McPeak et al., 2012; ODI, 2006), as well as changes related to intra-household relations, educational attainment, gender roles (Fratkin, 1992; Krätli, 2009; Pantuliano, 2002), conflict and insecurity (Oba, 1992) and denudation of the environment (Ibid.; Blackwell, 2010; McCabe, 1990).

The feasibility of investigating these possible effects is dependent on the availability of evidence identified during the systematic search process. Where possible, this review aims to make attributable - and, at a minimum, contributable - inferences about the provision of food assistance in the context of humanitarian interventions and various aspects of pastoralist livelihoods.

\section{$1.3 \quad$ RESEARCH QUESTIONS}

The review aims to identify, synthesize, evaluate the strength of evidence and estimate both the short- and long-term effects that the provision of food assistance in the context of humanitarian crises has had on pastoralist livelihoods from 1967 onwards. In order to address this primary objective, a number of research questions were posed to the reported and available literature:

- Q1: In what ways have pastoralist livelihood strategies changed since 1967 (and to what extent have non-pastoralist livelihood strategies supplanted them)? What is the potential causal relationship between these changes and food assistance?

- Q2: In what ways have pastoralist asset dynamics changed? What is the potential causal relationship between these changes and food assistance?

- Q3: In what ways have income dynamics changed? What is the potential causal relationship between these changes and food assistance?

\footnotetext{
${ }^{4}$ The reasons for this being the scope of the review are discussed in detail in the review protocol.
} 
- Q4: In what ways have mobility patterns changed? What is the potential causal relationship between these changes and food assistance?

- Q5: What types of in-kind food assistance interventions have been offered to pastoralist populations in the context of humanitarian crises? How have these interventions, the nature of the strategies, the distribution of food assistance and its duration changed over time?

- Q6: In what ways do pastoralists use the food they receive? Do they consume it, or use it as livestock feed or as a commodity to sell or barter?

- Q7: In what ways has access to food and non-food items in pastoralist areas changed, including in relation to markets? What is the potential causal relationship between these changes and food assistance?

- Q8: What household-level shifts have taken place among pastoralist populations? What is the potential causal relationship between these changes and food assistance?

- Q9: What individual-level shifts have taken place among pastoralist populations? What is the potential causal relationship between these changes and food assistance?

- Q10: What shifts have taken place in the social relations of pastoralist populations, including in relation to social support networks? What is the potential causal relationship between these changes and food assistance?

- Q11: In what ways have the security conditions within which pastoralist livelihoods take place changed? What is the potential causal relationship between these changes and food assistance?

- Q12: What are the populations and regions affected by food assistance interventions targeting pastoralists? What are the commonalities and variations between these populations and regions?

Population, intervention, control and outcome (PICO) parameters

\section{Population}

This evidence synthesis considers all pastoralist populations, as previously defined. As specified in the review protocol, it also aims to investigate the commonalities and variations between the populations (primarily in terms of livelihood patterns, including migration practices, but also, where relevant, governance systems and interactions with non-pastoralist populations) in order to facilitate sub-grouping and apt comparison, and thereby make inferences regarding the relationship between the provision of food assistance and livelihood changes.

\section{Interventions/issues}

The review examines in-kind food assistance provision during or after humanitarian crises, as previously defined. To this end, it aims to identify humanitarian crises that have affected pastoralist populations. It also provides an overview of food assistance interventions targeting pastoralist populations that have been undertaken in the wake of these crises. Specifically, it aims to identify the issues, types of intervention and the specific ways in which they have targeted pastoralist populations.

\section{Comparator/context}

The review assesses the changes that the livelihoods of pastoralist populations have undergone in the wake of in-kind food assistance provision, and the changes to the context where they live. Where data exists, it aims to compare the changes experienced by any relevant population to pastoralist populations (especially ones living in similar contexts) who have not received in-kind food assistance, pastoralist populations who have received other types of food assistance (including cash transfers and vouchers), pastoralist populations who have been affected by different kinds of humanitarian crises (e.g. slow- as opposed to rapid-onset ones), pastoralist populations who have not experienced comparable humanitarian crises, and to the historical experiences of the same population. 


\section{Outcomes}

The review investigates potential impacts (detailed below) of in-kind food assistance on pastoralist populations. Whenever possible, it aims to disaggregate the evidence of possible impacts by age, gender, mobility patterns, populations (such as ethnic groups) and regions of interest, the type of food assistance interventions, the type of humanitarian crisis in question (slow- or rapid-onset; natural in origin, man-made or a combination) and other relevant attributes.

The review also considers the extent to which food assistance interventions are potentially responsible for specific changes in pastoralist livelihoods. These changes may include:

- shifts in livelihood strategies, especially changed preferences for specific assets - animal species or (among agropastoralists) access to land for seasonal agricultural production - or diversification of strategies to include non-pastoral production and employment, as well as dependency on food assistance

- asset dynamics, including sale and acquisition of assets and asset types

- income dynamics, including new sources of income (e.g. from non-pastoral employment and remittances) and (re)distribution of income within populations

- shifts in mobility patterns, including sedentarization and urban migration

- shifts in social relations, including in social support networks

- household-level shifts, including changes in household size, household income, distribution of assets, the role of household members in specific aspects of livelihood strategies (determined by age, gender and other attributes) and household splitting

- individual-level shifts, such as acquisition of new skills, educational attainment, gender roles and health or disease outcomes

- conflict and insecurity.

The review seeks to identify the specific ways in which pastoralist livelihoods and related phenomena have changed and to determine the extent to which they can be associated with food assistance interventions in response to humanitarian crisis. In particular, it aims to address the possible causal mechanisms that may link specific food assistance interventions and livelihood changes. 
Because of the nature of anticipated evidence, the relatively broad character of the research objective and time constraints, a full systematic review of evidence was not feasible. Instead, the scoping study methodology was selected for the review. ${ }^{5}$ While more adaptable and applicable to broader topics and a wider range of study designs than a systematic review, the scoping study methodology is still underpinned by the requirement of rigorous and transparent handling of all stages of the research process, which should be documented to enable replication (Arksey and O'Malley, 2005: 22; DiCenso et al., 2010: 20). This review adds to traditional scoping study methods by assessing study quality, which is not typically included in this form of evidence synthesis.

In all, the review seeks to summarize evidence on the impact of in-kind food assistance on pastoralists' livelihoods during and after a humanitarian crisis. It aims to achieve this by:

- systematically identifying all available evidence in academic and grey literature sources

- comparing and contrasting the effects of assistance delivered (by population, assistance type, etc.)

- synthesizing identified data and concepts to generate summary statements on available evidence

- assessing the strength of evidence, as appropriate, for the body of identified studies

- identifying gaps in the current evidence base and further commenting on future research needs in this space.

The research process involved the following steps:

- protocol development

- implementation of the search strategy

- document screening

- assessment of the strength of evidence and causal inferences in included publications

- data extraction and evidence synthesis.

\section{$2.1 \quad$ PROTOCOL DEVELOPMENT}

The purpose of the protocol (Czuba and O'Neill, 2016) was to clearly describe the proposed research methodology. The protocol set out the theoretical background to the study, its purpose and objectives, the research questions and PICO parameters, and the review methodology. The protocol was peer-reviewed and amended before commencement of the subsequent steps in the research process.

\section{$2.2 \quad$ IMPLEMENTATION OF THE SEARCH STRATEGY}

Following the methodologically rigorous scoping review approach proposed by Arksey and O'Malley (2005: 48) to conduct a systematic search, comprehensive literature searches were conducted in June 2016 in the following databases: Medline, CAB Abstracts, Cochrane Database of Systematic Reviews, ARTFL-FRANTEXT, International Bibliography of the Social Sciences, LISA, LILACS, IDEAS, Web of Science Core Collection, PAIS International, Africa Wide NiPAD and Google Scholar. Searches were designed by a medical librarian (Ana Patricia Ayala), using a combination of controlled vocabulary (MeSH, Emtree) and free text terms. The strategy was modified as necessary for individual databases. The search strategy was limited to English and French, and to sources published between January 1967 and June 2016. Search terms included: pastoral ${ }^{*}$, domestic livestock, humanitarian intervention, relief, aid, crisis management, in-kind, assist* and animal husbandr* ${ }^{6}$

\footnotetext{
${ }^{5}$ The reasons for this choice are discussed in the review protocol (Czuba and O'Neill, 2016).

${ }^{6} \mathrm{An}$ asterisk indicates that a word that has been truncated in order to search for variants.
} 
Targeted searches for grey literature (i.e. difficult to locate or unpublished material) by searching websites that captured the topic were also undertaken and included a large number of websites, including those of the following organizations and institutions: Addis Ababa University, African Development Bank, Centre for International Development, Danish International Development Agency, Deutsche Gesellschaft für Internationale Zusammenarbeit, Feinstein International Center, FHI 360, Humanitarian Aid and Civil Protection Department (ECHO) of the European Commission, Institute for Development Studies at the University of Nairobi, Institute for Global Health at University College London, Institute of Development Studies at the University of Sussex, International Institute for Environment and Development, OpenGrey, Swedish International Development Agency, World Health Organization and others. The sources and search strategy strings are detailed in Appendix 1.

\section{$2.3 \quad$ DOCUMENT SCREENING}

Inclusion criteria, derived from the PICO parameters, were applied incrementally over the course of two screening rounds to identify potentially relevant publications. Citations were imported directly into EndNote ${ }^{\mathrm{TM}}$ (Thomson Reuters, Philadelphia, PA, USA). Subsequently, citations were imported directly into systematic review software Covidence ${ }^{\mathrm{TM}}$ (Veritas Health Innovation Ltd., Deerfield, IL, USA) for title and abstract relevance screening and data characterization of full articles.

\section{Round 1 (R1): Title and abstract review for potential relevance}

In the first round of reviews, titles and abstracts of potentially relevant publications identified during the searches were screened by two researchers (Karol Czuba and Tyler J. O'Neill) independently for further consideration if they satisfied the following inclusion criteria:

- Does the study report on a pastoralist population (Appendix 2)? (Yes/No/Unclear)

- Has the reported population been affected by a humanitarian crisis in the period since 1967 or can it be compared with a population that has been affected by a humanitarian crisis or emergency (a comparative population is desired but not necessary for inclusion, given the suspected limited availability of data)? (Yes/No/Unclear)

- Did the response to the crisis or emergency include the provision of in-kind food assistance? (Yes/No/Unclear)

\section{Round 2 (R2): Full text review for potential relevance}

Studies that did not report 'no' in any of the inclusion criteria from R1 were included in R2. In $\mathrm{R} 2$, the researchers re-applied inclusion criteria to potentially relevant publications from R1. Studies included at this stage were also required to satisfy the following criterion:

- Does the study report evidence of potential impact of food assistance on pastoralist populations? (Yes/No/Unclear)

Studies that failed to meet the inclusion criteria during R1 and R2 (i.e. failed to respond 'yes' to all inclusion criteria) were excluded from further consideration. All inclusions and exclusions were recorded in Covidence ${ }^{\mathrm{TM}}$.

\footnotetext{
${ }^{7}$ Software used in the review differs from software proposed in the review protocol, which envisioned the use of RefWorks@ and DistillerSR ${ }^{\mathrm{TM}}$, instead of EndNote ${ }^{\mathrm{TM}}$ and Covidence ${ }^{\mathrm{TM}}$ respectively. After exploration of ease of use and integration of identified references across platforms, the research team selected EndNote ${ }^{\mathrm{TM}}$ and Covidence ${ }^{\mathrm{TM}}$. Both software alternatives are comparable in function, but EndNote ${ }^{\mathrm{TM}}$ integrates better with Covidence ${ }^{\mathrm{TM}}$, whereas RefWorks@ takes increased time and effort, with greater risk of error when importing in to DistillerSR ${ }^{\mathrm{TM}}$.
} 
$2.4 \quad$ EVIDENCE ASSESSMENT

The strength of evidence in the individual included publications and the overall strength of the body of evidence were appraised using the DFID Assessing the Strength of Evidence note (DFID, 2014). ${ }^{8}$

The assessment criteria for individual publications identified in the DFID note are specified in Figure 2.1. The note specifies the following categories to which publications can be assigned, depending on the strength of evidence that they report:

- high - the publication comprehensively addresses multiple principles of quality (as recommended in the note, publications which satisfy this criterion are identified with the symbol ' $\uparrow$ ').

- moderate - there are some deficiencies in attention to principles of quality (identified with ' $\rightarrow$ ').

- low - there are major deficiencies in attention to principles of quality (identified with ' $\downarrow$ ').

The note recommends that strength of evidence should be clearly indicated when the findings reported in a publication are discussed. This review follows this recommendation; all in-text citations of included publications are accompanied by an arrow symbol which indicates the strength of evidence.

The review also follows the criteria for assessment of bodies of evidence developed in the note:

- the (technical) quality of the studies constituting the body of evidence (or the degree to which risk of bias has been addressed):

high - the large majority of reviewed publications report evidence of high strength, demonstrating adherence to the principles of research quality

moderate - approximately equal numbers of reviewed publications are of a high, moderate and low quality, as assessed according to the principles of research quality low - the large majority of reviewed publications report evidence of low strength, demonstrating significant deficiencies in adherence to the principles of quality;

- the size of the body of evidence:

- large

- medium

- small;

- the context in which the evidence is set:

- global context-specific;

- the consistency of the findings produced by studies constituting the body of evidence:

- consistent - a range of publications points to identical or similar conclusions

- inconsistent (contested) - at least one publication directly refutes or contests the findings of other publications carried out in the same context or under the same conditions

- mixed - publications based on a variety of different designs or methods, applied in a range of contexts, have produced results that contrast with those of other publications;

\footnotetext{
${ }^{8}$ The DFID guidelines were applied instead of GRADE, for two reasons. First, DFID - which has provided funding for this review requires that the guidelines should be comprehensively applied in the production of DFID evidence papers. Second, GRADE is designed primarily for controlled trials. Nearly all the included publications are case studies, and it is therefore not appropriate to apply the GRADE tool to them (they are descriptive studies, not observational). During development of the protocol, the research team anticipated finding cohort or cross-sectional studies, which would have made the use of GRADE appropriate. Following document screening, however, we made a post hoc decision to apply a more appropriate tool given the body of evidence we identified.
} 
- the overall strength of the body of evidence:

- very strong - high-quality body of evidence, large in size, consistent and contextually relevant

strong - high-quality body of evidence, large or medium in size, highly or moderately consistent and contextually relevant

medium - moderate-quality studies, medium size evidence body, moderate level of consistency

limited - moderate- to- low-quality studies, medium-size evidence body, low levels of consistency

no evidence.

\section{Figure 2.1: DFID strength of evidence assessment criteria for individual} publications

\begin{tabular}{|c|c|}
\hline $\begin{array}{l}\text { Principles of } \\
\text { quality }\end{array}$ & Associated questions \\
\hline \multirow{3}{*}{$\begin{array}{l}\text { Conceptual } \\
\text { framing. }\end{array}$} & Does the study acknowledge existing research? \\
\hline & Does the study construct a conceptual framework? \\
\hline & Does the study pose a research question or outline a hypothesis? \\
\hline \multirow[t]{3}{*}{ Transparency. } & Does the study present or link to the raw data it analyses? \\
\hline & Does the study declare sources of support/funding? \\
\hline & $\begin{array}{l}\text { Does the study demonstrate why the chosen design and method are well suited to the } \\
\text { research question? }\end{array}$ \\
\hline $\begin{array}{l}\text { Cultural } \\
\text { sensitivity }\end{array}$ & $\begin{array}{l}\text { Does the study explicitly consider any context- specific cultural factors that may bias the } \\
\text { analysis/findings? }\end{array}$ \\
\hline \multirow[t]{4}{*}{ Validity } & To what extent does the study demonstrate measurement validity? \\
\hline & To what extent is the study internally valid? \\
\hline & To what extent is the study externally valid? \\
\hline & To what extent is the study ecologically valid? \\
\hline \multirow[t]{3}{*}{ Reliability } & To what extent are the measures used in the study stable? \\
\hline & To what extent are the measures used in the study internally reliable? \\
\hline & $\begin{array}{l}\text { To what extent are the findings likely to be sensitive/changeable depending on the } \\
\text { analytical technique used? }\end{array}$ \\
\hline \multirow[t]{3}{*}{ Cogency } & Does the author 'signpost' the reader throughout? \\
\hline & $\begin{array}{l}\text { To what extent does the author consider the study's limitations and/or alternative } \\
\text { interpretations of the analysis? }\end{array}$ \\
\hline & Are the conclusions clearly based on the study's results? \\
\hline
\end{tabular}

Source: DFID (2014: 14)

For a summary of the findings, see Figure 4.8.

\subsection{DATA EXTRACTION AND EVIDENCE SYNTHESIS}

Data abstracted from the included publications is presented in Figure 4.1. The subsequent sections describe the publications in greater detail and synthesize the evidence about the impacts of food assistance provided to pastoralists in the context of humanitarian emergencies. 
The search initially identified a total of 23,424 titles from academic databases and an additional 1,442 titles from grey literature sources (Figure 3.1; Appendix 1). After automatic de-duplication, 17,108 titles (68.8 percent of the total) were moved forward for title and abstract screening. Upon further assessment of documents, an additional 1,713 were manually identified as duplicates and removed, resulting in a total of 15,395 titles and abstracts (65.7 percent) included in R1. In all, 72 publications ( 0.3 percent) satisfied R1 criteria and qualified for further assessment in R2. Upon retrieval of full documents, a further 48 ( 0.2 percent) were deemed to be non-relevant as they did not report the provision of food assistance to pastoralists during a humanitarian crisis. In total, 24 documents ( 0.1 percent) were further assessed for data abstraction and assessment of the strength of evidence.

\section{Figure 3.1: Flowchart demonstrating the process of identification through to selection of documents included in the review}

Records identified through academic database searching $(n=23,424)$
Additional records identified through grey literature sources $(n=1,442)$

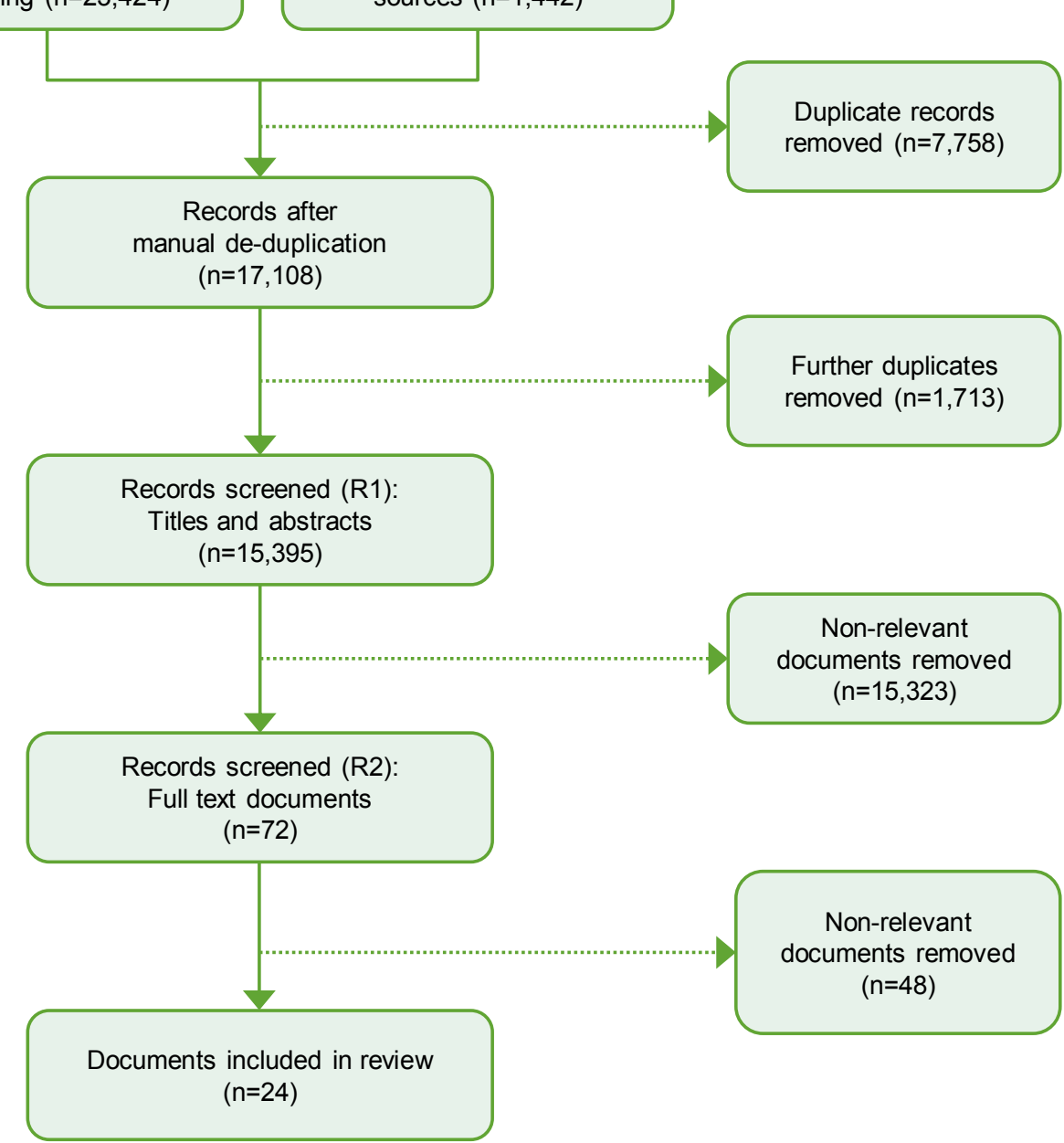


$3.2 \quad$ INCLUDED PUBLICATIONS

Records identified through academic databases and grey literature sources were restricted to English and French; only those written in English met study inclusion criteria. The majority of included publications (54 percent) have been published since 2000 (range: 1983 to 2015). They report provision of food assistance that took place between 1920 and 2012 (Figure 4.1). Most publications do not explicitly identify their research design; instead, they were classified by the research team based on the information they contained. Of reported research types, the majority of publications are primary studies $(n=20)$; the remaining publications are secondary studies $(n=2)$ or do not contain information that would allow identification of the research type (classified as 'unclear'; $n=2$ ). The research design of the two secondary studies is classified as 'other review' $(n=2)$. The research design is impossible to identify in one publication ('unclear'; $n=1$ ). The remaining publications are observational $(n=21)$. The majority of publications are case studies $(n=19)$; the case studies rely on qualitative $(n=10)$, quantitative $(n=4)$ and mixed $(n=5)$ methods. Additionally, one study has a quasi-experimental design akin to a natural experiment, although it employs qualitative methods $(n=1)$. There is also a quantitative case control study $(n=1)$ among the included publications. Three studies are classified as 'other' $(n=3)$. One compares the experiences of two countries (Ethiopia and Sudan; quantitative). Another summarizes case studies published elsewhere (qualitative). The third is a news story from the popular press (qualitative). With the exception of the news story, the included publications are academic and/or peer-reviewed $(n=23)$.

As recommended by DFID (2014), the study characteristics of each included publication are stated in-text (together with assessed strength of evidence indicated by arrow symbols) when the evidence reported in the publication is discussed. The review uses the following abbreviations to identify the study characteristics:

- Design:
P: primary
S: secondary
O: observational
QE: quasi-experimental
OR: other review
UN: unclear
CS: case study
CC: case control
NE: natural experiment.

- Methodological approach:

- Qual: qualitative

Quant: quantitative

M: mixed.

Most of the included publications report food assistance provision in East Africa and the Horn of Africa (Sudan, Eritrea, Djibouti, Ethiopia, Somalia, Uganda and Kenya) $(n=20)$. Studies from Algeria $(n=1)$, Niger $(n=1)$ and Mongolia $(n=2)$ are also included. The following African pastoralist ethnic groups are reported: Beja $(n=2$; in one publication, the Amar'ar/Atmaan and Bishariyyn groups of the Beja are specifically identified), Gabbra $(n=1)$, Oromo $(n=2$; the Borana sub-group is specifically identified in one publication), Pokot $(n=2)$, Rashaida $(n=1)$, Saharawis $(n=1)$, Somalis $(n=3)$ and Turkana $(n=5)$. Additionally, studies report unidentified pastoralist populations in Djibouti $(n=1)$, Eritrea $(n=1)$, Ethiopia $(n=2)$, Kenya $(n=5)$, Niger $(n=1)$, Somalia (although these are presumably Somalis; in accordance with evidence synthesis conventions, because the population is not explicitly identified it is not reported here; $n=3)$ and Sudan $(n=2)$. Mongolian herders are identified as recipients of food assistance in both publications from Asia. The most frequently reported mobility pattern is nomadism $(n=14)$; agropastoralism is reported twice $(n=2)$. Ten publications fail to report the mobility patterns of reported populations. Only one publication presents an outcome disaggregated by gender and only five explicitly note that both men and women are included in the observed populations. Finally, studies report a large range of individuals potentially receiving food aid in response to a humanitarian crisis (range: 6,000 to an estimated 20 million). 
The majority of study populations have experienced drought $(n=21)$ as the reported humanitarian crisis. Less frequently, but often in conjunction with drought, the publications report conflict $(n=3)$, famine $(n=4)$, flood $(n=2)$ and disease $(n=1)$. Both studies from Mongolia report $d z u d(n=2)$ as the humanitarian crisis affecting the population of interest. One publication fails to report sufficient information regarding the reported humanitarian crisis. Unconditional provision of food in-kind is the most frequently reported modality of food assistance $(n=13)$; food-for work $(n=2)$ and food-for-livestock exchange $(n=1)$ are also documented. Nine studies fail to detail the modality of provision of food assistance. Half of included studies $(n=12)$ report the provider of food aid. The categories of providers include national governments $(n=4)$, the United Nations and its specialized agencies $(n=5)$, NGOs $(n=7)$ and religious bodies $(n=2)$. Several publications report more than one provider. The duration of aid provision varies, when reported $(n=8)$, from one to 20 years.

\section{OUTCOMES REPORTED BY INCLUDED PUBLICATIONS}

The impacts of the provision of in-kind food assistance during a humanitarian crisis are reported in all included publications. Some publications report more than one outcome measure.

Based on abstracted data, the review team has organized outcomes into six thematic areas: (i) changes in livelihood strategies and asset and income dynamics $(n=11$; research questions 1 , 2 and 3); (ii) access, use and dependency on food assistance ( $n=7$; research questions 5, 6 and 7); (iii) changes in social relations ( $n=4$; research question 10); (iv) security and governance $(n=4$; research question 11$)$; $(v)$ mobility patterns $(n=9$; research question 4$)$; and (vi) household- and individual-level socio-demographic shifts $(n=7$; research questions 8 and 9). Some publications report more than one outcome and are included in multiple themes. Given the limited number of relevant publications included in the review, the research team was unable to disaggregate evidence beyond geographical region (i.e. Horn of Africa, Africa other, Mongolia). The findings on livelihood changes in Kenya, which are reported by multiple sources (but report mixed evidence), offer a partial exception. Furthermore, for the same reason and also because publications do not contextualize outcomes by age, gender or mobility patterns, we were unable to disaggregate these characteristics.

\section{ASSESSMENT OF THE STRENGTH OF EVIDENCE AND CAUSAL CLAIMS}

The publications have been evaluated with respect to standards outlined in the DFID Assessing the Strength of Evidence note (DFID, 2014). These standards correspond to the questions presented in Figure 2.1. Figure 4.8 reports the extent to which the publications conform to the standards.

The publications generally satisfy the conceptual framing standards. Seventeen publications acknowledge existing research and 18 pose a research question (or questions) or outline a hypothesis (or hypotheses). The research team has interpreted the term 'conceptual framework' broadly to include publications $(n=20)$ that make theoretical claims of any kind.

The transparency standards are followed less consistently. Seventeen publications present or link to the raw data that they analyze (this includes both formal reporting of results obtained from quantitative analysis of datasets and more offhand references to findings obtained from e.g. interviews and focus groups in qualitative sources); however, only one declares its sources of funding.

The majority of publications do not satisfy the appropriateness, cultural sensitivity, validity or reliability standards. No publication justifies the choice of the research design and methods or their appropriateness to the research questions. Cultural sensitivity of the research undertaken is also not considered by any publication. The six publications that rely on observational quantitative methods appear to be internally valid and use valid measures, but these issues are not explicitly addressed. The remaining publications do not demonstrate measurement validity in any way; their internal validity is also unclear. Based on information contained in these publications, it is impossible to determine whether the validity and reliability standards 
are met. Given that these criteria are not satisfied, none of the included publications provides a high strength of evidence for the criteria of internal measurement validity.

More publications satisfy at least some of the cogency standards. All publications other than the three very short ones $(n=21)$ 'signpost' the reader throughout the text. In most cases $(n=18)$, conclusions appear to be based on the results reported in the publications. Only one publication, however, explicitly addresses the limitations of the reported research project.

Overall, based on the publications' conformity with the DFID standards, this review does not consider the strength of evidence reported in any of the publications to be high. The strength of evidence of 13 publications can be classified as moderate, while there are 11 publications of low strength of evidence.

Because of the large number of low-strength-of-evidence studies among the included publications and the lack of any high-strength studies, the quality of the body of evidence is classified as low, based on the DFID assessment criteria. The size of the body of evidence $(n=24)$ can be classified as medium. The distribution of the publications' geographic focus roughly corresponds to the geographic distribution of pastoralists in the world: most of them report findings from East Africa and the Horn; the remaining ones address the provision of food assistance in other parts of Africa and in Mongolia. For this reason, the context of the body of evidence can be classified as global, although the possibility of reporting bias should be noted because all the included sources are in English. As the subsequent section demonstrates, the publications report different - and, at times, seemingly contradictory impacts of the provision of food assistance on specific aspects of pastoralist livelihoods. Because they report findings from multiple contexts, however, the consistency of the findings is classified as mixed, rather than inconsistent (or contested).

The characteristics of the body of evidence indicate that its overall strength should be classified as limited: the publications have low to moderate strength of evidence; the size of the body of evidence is medium; the levels of consistency are relatively low. The assessment of the overall strength of the body of evidence is summarized in Figure 3.2.

Figure 3.2: Overall strength of the body of evidence

\begin{tabular}{|l|l|}
\hline Quality of the body of evidence & Low \\
\hline Size of the body of evidence & Medium \\
\hline Context of the body of evidence & Global \\
\hline Consistency of the findings & Mixed \\
\hline Overall strength of the body of evidence & Limited \\
\hline
\end{tabular}

\section{$3.5 \quad$ NARRATIVE SYNTHESIS OF RESULTS}

This section is organized according to the six themes introduced earlier in the Results section.

\section{Changes in livelihood strategies and asset and income dynamics}

This theme corresponds to three of the research questions:

- Q1: In what ways have pastoralist livelihood strategies changed since 1967 (and to what extent have non-pastoralist livelihood strategies supplanted them)? What is the potential causal relationship between these changes and food assistance?

- Q2: In what ways have pastoralist asset dynamics changed? What is the potential causal relationship between these changes and food assistance?

- Q3: In what ways have income dynamics changed? What is the potential causal relationship between these changes and food assistance? 


\section{Changes in livelihood strategies}

These questions address some of the most important aspects of the potential impacts of food assistance on pastoralist livelihoods. The evidence on these impacts obtained from the included publications is, however, very limited.

The best available evidence about the impact of food assistance on pastoralist livelihoods is from McCabe (1990; P, QE, Qual, NE, $\rightarrow$ ), who reports that the Ngilukumong, Ghiyapakuno, Ngikamatak and Ngibocheros sections of the Turkana in Kenya that received food assistance during the 1979-81 drought witnessed a breakdown of indigenous coping strategies for drought. No similar development occurred among the Ngisonyoka of southern Turkana, who did not receive food assistance. McCabe outlines a causal chain in which the attraction of free food led to the settling of pastoralist households near relief distribution centres; the presence of large numbers of pastoralists - and their herds - around the relief centres in turn contributed to denudation of the environment, which forced livestock to forage on sparser and less nutritious plants than they would have away from the settlements. (The negative impact of food assistance on the environment is also mentioned, albeit without providing any details, by Pantuliano, 2007 [P, O, Qual, CS, $\rightarrow$ ].) Inevitably, livestock losses through starvation or disease followed, undermining the basis of pastoralist livelihoods. The relief centres, McCabe observes, 'were, to some extent, creating their own clients'. He notes differences between the southern (Ngisonyoka) and northern (Ngilukumong, Ghiyapakuno, Ngikamatak and Ngibocheros) Turkana that could account for some of the variation; nonetheless, the stark contrast between the two populations strongly indicates that the provision of food assistance had negative consequences for the livelihoods of the Turkana who received it between 1979 and 1981.

The long-term consequences and external validity of developments reported by McCabe are not clear. According to Bersaglio et al. (2015 [P, O, Qual, CS, $\rightarrow$ ]), a small-scale food assistance intervention in Turkana contributed to movement away from pastoralist livelihoods among the beneficiaries while simultaneously improving their quality of living. Snow (1984 [UN, Qual, CS, \]) finds that food-for-work projects in Turkana encouraged a shift towards cash crop agricultural production. Nangulu (2009 [P, O, Qual, CS, $\downarrow]$ ) claims that livelihood strategies of the Kenyan Pokot, the southern neighbours of the Turkana, have been undermined by food assistance. Evidence from the multiple publications which report on Kenya is, therefore, mixed.

Outside Kenya, and similarly to Nangulu, Pantuliano (2002 [S, OR, Qual, CS, $\rightarrow$ ]) reports negative impacts of food assistance among the Beja in Sudan. The Overseas Development Institute (2006 [P, O, Qual, CS, $\downarrow])$ claims that 'the humanitarian response to the crisis in the Greater Horn of Africa has done very little, to date, to protect livelihoods'. The assessment that these publications offer suggests detrimental impacts of food assistance on pastoralist livelihoods in a large number of settings.

Effective comparisons with pastoralist populations that have not received food assistance with the exception of the Ngisonyoka reported by McCabe (1990) - do not appear to be possible given the lack of reported evidence. Abbink (1993) observes that the Suri of Lower Omo Valley in Ethiopia were able to successfully weather the severe famine of 1985 and preserve their livelihoods without access to food assistance, but their traditional coping strategies were complemented by exploitation of gold and investment in automatic weapons. Given the unique circumstances, the experience of the Suri does not offer generalizable insights into the viability of pastoralist livelihood strategies in the context of humanitarian crises in the absence of food assistance.

\section{Changes in asset dynamics and income}

Evidence on asset dynamics is even more limited and inconclusive. All of it is also drawn from Kenya. Buchanan-Smith and Barton (1999 [P, O, M, CS, $\rightarrow]$ ) report that the provision of food assistance in Wajir in Kenya resulted in a reduction of livestock sales, which were monitored by the World Bank's Arid Lands Resource Management Project. Bush (1995 [P, $\mathrm{O}, \mathrm{M}, \mathrm{CS}, \rightarrow]$ ) reports that provision of food assistance in Turkana led to a strengthening of herd growth and simultaneously filled income gaps among recipients. The effects that these interventions have had on pastoralist economies suggest that food assistance does not necessarily always undermine pastoralist livelihoods. 
The quality of the publications which report on this theme is moderate. The body of evidence is small and context-specific. The findings reported by the publications are mixed. The overall strength of evidence relating to this theme is medium.

Given the inadequate evidence (and its limited scope), the three research questions cannot be answered conclusively. It appears, however, that the provision of food assistance has, at least in some cases, contributed to the erosion of pastoralist livelihoods, although it might also have enabled some pastoralists to hold on to their assets - including livestock - and supported redistribution of income.

The results reported in this section are summarized in Figure 4.2.

\section{Mobility patterns}

This theme corresponds to the following research question:

- Q4: In what ways have mobility patterns changed? What is the potential causal relationship between these changes and food assistance?

The included publications present more evidence on changes in mobility patterns than any other theme. Although a number of these publications have a low strength of evidence, the consistency of the information that they provide suggests the veracity of their findings. Adow (2008 [UN, O, Qual, CS, $\downarrow$ ]), Bersaglio et al. (2015 [P, O, Qual, CS, $\rightarrow$ ]), McCabe (1990 [P, QE, Qual, NE, $\rightarrow$ ]) and Ngunjiri (1989 [P, O, Qual, CS, $\downarrow])$ in Kenya and Kilby (1993 [S, OR, Qual, CS, $\downarrow]$ ) and Pantuliano (2002 [S, OR, Qual, CS, $\rightarrow$ ] and 2007 [P, O, Qual, CS, $\downarrow]$ ) in Sudan all observe increased rates of sedentarization among the beneficiary populations and attribute it to the provision of food assistance. The most plausible causal connection between food assistance and sedentarization is made by McCabe (and presented in the section above on 'Changes in livelihood strategies'). While it is clear that sedentarization (and in some settings urbanization) has taken place among a large number of pastoralist populations, the relationship between this process and food assistance is not always clear. Other humanitarian interventions, development projects and broader economic changes may also influence the mobility patterns of pastoralists.

The quality of the publications which report on this theme is low. The body of evidence is small and context-specific. The findings reported by the publications are consistent. The strength of evidence relating to this theme is limited.

The results reported in this section are summarized in Figure 4.3.

\section{Access to food assistance, use of food assistance and dependency}

This theme corresponds to three research questions:

- Q5: What types of in-kind food assistance interventions have been offered to pastoralist populations in the context of humanitarian crises? How have these interventions, the nature of the strategies, the distribution of food assistance and its duration changed over time?

- Q6: In what ways do pastoralists use the food they receive? Do they consume it, or use it as livestock feed or as a commodity to sell or barter?

- Q7: In what ways has access to food and non-food items in pastoralist areas changed, including in relation to markets? What is the potential causal relationship between these changes and food assistance?

The included publications report the impacts of three types of food assistance: food provided unconditionally $(n=12)$, in return for work $(n=2)$ and in return for livestock $(n=1)$. The last modality involved the exchange of livestock which, it was believed, would not survive a 
drought, in return for food (Ngunjiri, 1989 [P, O, Qual, CS, $\downarrow]$ ). Because only three interventions in which food assistance was distributed in return for assets or work are reported, is not clear from the publications in what ways the provision of food assistance has changed over time. (The types of food assistance provided are reported for each publication in Figure 4.1.)

Problems related to the targeting of food assistance are noted by a number of publications. Pantuliano (2002 [S, OR, Qual, CS, $\rightarrow$ ]) reports that distribution of food assistance to the Beja was captured by elites, who excluded some groups within the population. Similarly, unequal distribution of food assistance caused controversy in Marsabit in Kenya (Lekapana, 2013 [P, O, M, CS, ل]). Fernandez-Gimenez et al. (2012 [P, O, M, CS, $\rightarrow]$ ) relate that in Mongolia targeting of poor households was considered by many members of the local population as unfair to those herders who worked hard to prepare for winter. Such controversies appear to be widespread and are also noted in excluded publications (e.g. Merten and Haller, 2009; Moris, 1988). In some cases (e.g. Pantuliano, 2002 [S, OR, Qual, $\mathrm{CS}, \rightarrow]$ ), they are evidently the result of sub-standard targeting that excludes potentially eligible beneficiaries; in others (e.g. Fernandez-Gimenez et al., 2012 [P, O, M, CS, $\rightarrow$ ]; Lekapana, 2013 [P, O, M, CS, $\downarrow]$ ), they may reflect the inherent difficulties of effective and equitable targeting in settings where universal distribution of food assistance is considered unnecessary. The latter modality of distribution, in which all pastoralists in an area affected by humanitarian crisis receive food assistance, appears to be rare and is reported only by Bush (1995 [P, O, M, CS, $\rightarrow]$ ). The amount of food assistance provided to pastoralists is also not always sufficient. Cicalese et al. (2009 [P, O, Quant, CS, $\rightarrow]$ ) report that food distributed to Saharawis in Algerian refugee camps was insufficient and nutritionally unbalanced, leading to widespread malnutrition. This deficiency of food assistance is not reported by other publications.

Only one publication reports unintended use of food assistance: according to Snow (1984 [UN, Qual, CS, $\downarrow$ ]), provision of food assistance in Turkana led to an increase in alcoholism as beneficiaries with adequate food supplies distilled corn that they received and sold it in their communities.

A number of publications claim that the provision of food assistance has led to dependency among the recipient population (Adow, 2008 [UN, O, Qual, CS, $]$ ]; Farzin, 1991 [P, O, Quant, CS, $\rightarrow$ ]; Lekapana, 2013 [P, O, M, CS, $\downarrow]$; Nangulu, 2009 [P, O, Qual, CS, $\downarrow]$ ). Most of them are classified as reporting evidence of low strength and - beyond noting their authors' impressions - they do not provide any evidence for this claim. While it is conceivable that populations who receive food assistance for extended periods of time may come to depend on them, the dependency thesis is not supported by evidence.

The included publications do not report the ways in which access to food and non-food items has changed in pastoralist areas.

The quality of the publications which report on this theme is low. The body of evidence is small and context-specific. The findings reported by the publications are consistent. The strength of evidence relating to this theme is limited.

The results reported in this section are summarized in Figure 4.4.

\section{Household- and individual-level socio-demographic shifts}

This theme corresponds to two research questions:

- Q8: What household-level shifts have taken place among pastoralist populations? What is the potential causal relationship between these changes and food assistance?

- Q9: What individual-level shifts have taken place among pastoralist populations? What is the potential causal relationship between these changes and food assistance?

There is effectively no evidence in the publications on household- and individual-level shifts such as changes in household size, distribution of assets, the role of household members in specific aspects of livelihood strategies, acquisition of skills or educational attainment. (The 
issue of household income is addressed in the section on livelihood changes and asset and income dynamics.) The exceptions are the issue of gender roles and health outcomes.

Gender is addressed in one publication. Snow (1984 [UN, Qual, CS, $\downarrow$ ]) notes that there was a growing tendency, encouraged (but not caused) by food assistance, for young Turkana women to seek alternatives to pastoralist livelihoods. Given the lack of corroborating evidence from other publications, the veracity of this finding cannot be confirmed.

The included publications include some evidence of a causal relationship between food assistance and the health of its recipients. Two publications offer negative assessments of the health impacts of food assistance. No author (2001 [P, O, Quant, CS, $\rightarrow$ ]) finds that because during famine in Ethiopia in 2000 food was distributed in feeding centres - large concentrations of susceptible people in one location could contribute to an increase in the transmission of infectious diseases such as measles and diarrhoea. According to Kilby (1993 [S, OR, Qual, CS, $\downarrow]$ ), food assistance had little positive effect on human mortality levels in Sudan, yet no clear reason for mortality was offered (i.e. due to food insecurity, disease or otherwise). It is not clear if either of these claims is based on empirical evidence. On the other hand, four publications report that the provision of food assistance has had positive impacts on health outcomes of its beneficiaries. Bush (1995 [P, O, M, CS, $\rightarrow$ ]), BuchananSmith and Barton (1999 [P, O, M, CS, $\rightarrow$ ]) and Taylor (1983 [P, O, Quant, CS, $\rightarrow$ ]) all argue that rates of malnutrition decreased because of access to food assistance. Bersaglio et al. (2015 [P, O, Qual, CS, $\rightarrow$ ]) observe a reduction in anxiety and 'enhanced spirituality' (and, thereby, increased well-being) among recipients of food assistance. While evidence is limited and offers varying assessments of the association between food assistance and health, the findings reported in Bush (1995 [P, O, M, CS, $\rightarrow$ ]), Buchanan-Smith and Barton (1999 [P, O, M, CS, $\rightarrow$ ]), and Taylor (1983 [P, O, Quant, CS, $\rightarrow$ ]) suggest that - at least in some settings and in the short term - food assistance can achieve its primary goal of addressing food insecurity.

The quality of the publications which report on this theme is moderate. The body of evidence is small and context-specific. The findings reported by the publications are mixed. The strength of evidence relating to this theme is limited.

The results reported in this section are summarized in Figure 4.5.

\section{Changes in social relations}

This theme corresponds to the following research question:

- Q10: What shifts have taken place in the social relations of pastoralist populations, including in relation to social support networks? What is the potential causal relationship between these changes and food assistance?

Evidence on shifts in social relations is limited. Snow (1984 [UN, Qual, CS, $\downarrow$ ]) reports that food assistance may have led to the creation of new power structures and the emergence of power brokers who challenge the authority of elders and the respect given to them. Pantuliano (2002 $[S$, OR, Qual, CS, $\rightarrow]$ ) reports similar developments among the Beja in Sudan, where problems related to the targeting of food assistance created a new class of 'food shaikhs', which brought about a modification of the existing social structure and the traditional interdiwab (lineage) dynamics founded on the exchange of resources and reciprocity. On the other hand, Bush (1995 [P, O, M, CS, $\rightarrow]$ ) finds that the Turkana who received food shared it with relatives and were thus able to maintain the fabric of their society.

It is difficult to draw conclusions from the scant evidence available. It appears that food assistance can contribute to changes in social relations, but the nature of these changes is likely to depend on the mode of its provision (for example, relying on local leaders can encourage the emergence of new power structures and, conceivably, strengthen the role of existing ones) and the local setting.

The quality of the publications which report on this theme is moderate. The body of evidence is small and context-specific. The findings reported by the publications are consistent. The strength of evidence relating to this theme is limited. 
The results reported in this section are summarized in Figure 4.6.

\section{Security and governance}

This theme corresponds to the following research question:

- Q11: In what ways have the security conditions within which pastoralist livelihoods take place changed? What is the potential causal relationship between these changes and food assistance?

While insecurity in pastoralist areas is reported by a large number of publications (e.g. Adams and Hawksley, 1989 [P, O, Qual, CS, $\downarrow$ ]; Bersaglio et al., 2015 [P, O, Qual, CS, $\rightarrow$ ]; Cicalese et al., 2009 [P, O, Quant, CS, $\rightarrow$ ]; Kilby, 1993 [S, OR, Qual, CS, $\downarrow$ ]; Overseas Development Institute, 2006 [P, O, Qual, CS, $\downarrow]$ ), none of them makes a causal connection between the provision of food assistance and the security situation in areas inhabited by its beneficiaries. Adams and Hawksley (1989 [P, O, Qual, CS, $\downarrow])$ note that during the crisis in Darfur during the 1980s, food assistance was believed to have saved a large number of lives. This finding is not surprising given the apparent impacts of food assistance on health outcomes (reported in the section above on 'Household- and individual-level sociodemographic shifts'), but is not corroborated by other publications.

A related issue that was not addressed in the research questions developed for the review protocol relates to the impact that food assistance may have on governance relations in pastoralist areas. As the findings of Pantuliano (2002 [S, OR, Qual, CS, $\rightarrow$ ]) and Snow (1984 [UN, Qual, CS, $\downarrow]$ ) indicate, food assistance may contribute to altering local power structures through the creation of power brokers used by providers to support its distribution. In a later publication, Pantuliano (2007 [P, O, Qual, CS, $\rightarrow$ ]) appears to confirm that this can have long-lasting effects on pastoralist communities. Furthermore, Snow (1984 [UN, Qual, CS, \]) hypothesizes that widespread provision of food assistance in Turkana was likely to lead to an increase in the level of control exercised over the region by the Kenyan government. This claim, however, is based on speculation, rather than empirical evidence.

The quality of the publications which report on this theme is low. The body of evidence is small and context-specific. The findings reported by the publications are consistent. The strength of evidence relating to this theme is limited (where governance is concerned) or non-existent (in relation to security).

The results reported in this section are summarized in Figure 4.7. 


\section{CONCLUSION}

This review has identified 24 publications that draw associations between the provision of inkind food assistance to pastoralists and changes in their health outcomes, livelihood strategies, asset and income dynamics, mobility patterns and political and social relations. Assessment of these publications permits some tentative conclusions to be drawn about the impacts of food assistance on pastoralists.

- Changes in livelihood strategies and asset and income dynamics:

- Asset dynamics:

- Provision of food assistance can lead to a reduction of livestock sales and strengthen herd growth.

Income dynamics:

- Provision of food assistance may fill gaps in pastoralists' incomes.

Livelihood strategies:

- Provision of food assistance can undermine the livelihood strategies of pastoralists.

The overall strength of the evidence relating to this theme is medium.

- Mobility patterns:

- Provision of food assistance can lead to changes in pastoralists' mobility patterns, and especially to sedentarization. This claim is made uniformly in a number of publications.

- The strength of evidence relating to this theme is limited.

- Access to food assistance:

- Food provided to pastoralists through food assistance interventions can be insufficient and unbalanced.

- Multiple publications claim that food assistance can lead to dependency, but there is no empirical evidence of such a causal relationship.

- According to one publication, provision of food assistance can lead to an increase in alcohol production.

- In some cases the modes of targeting of food assistance have led to internal controversy within pastoralist communities. Elsewhere, targeting has effectively encouraged the emergence of new political leaders who have sought to channel assistance to their clients and, by extension, restricted some intended beneficiaries' access to food.

- The strength of evidence relating to this theme is limited.

- Household- and individual-level socio-demographic shifts:

- Provision of food assistance can encourage pastoralist women to seek alternative livelihood strategies.

- According to most publications, access to food assistance leads to a decrease in malnutrition. Others report, however, that food assistance can have negative impacts on recipients' health outcomes.

The strength of evidence relating to this theme is limited.

- Social relations and governance:

- Provision of food assistance can both strengthen relations within existing social networks and contribute to the emergence of new political leaders (and displacement of their predecessors).

- The strength of evidence relating to these issues is limited.

- Security:

- The publications do not make a causal link between the provision of food assistance and security. 


\subsection{LIMITATIONS}

As the findings reported above suggest, the conclusions that this review can make are only tentative, not only because of the small number of included publications but also because of the limited strength of evidence that they provide. No included publication is based on experimental data. Only one takes advantage of a quasi-experimental research design that enables the author to effectively compare the impacts of food assistance on a pastoralist population with a control group that did not receive food assistance. Some publications make plausible - but unavoidably far from conclusive - causal claims based on credible analysis of survey or qualitative data. However, in most publications - a number of which have been published in peer-reviewed journals - causal claims are made offhand and without reference to analysis or data on which they are based.

Due to the limited strength of evidence assessed in the included body of publications, the conclusions of this review are necessarily tentative. In addition to laying the foundation for further research examining the causal pathways contributing to impacts of food assistance provided to pastoralist populations in the context of humanitarian crises, the included publications make two additional important contributions to the future of aid.

First, the validation of current findings on impacts on pastoralist livelihoods highlights the necessity for further population-based research. While the research team acknowledges that the challenges involved in planning and conducting controlled trials may be deemed logistically difficult and, in some cases, unethical, cohort designs (prospective cohort studies as well as retrospective cohort designs which rely on validated methods) may prove to be especially useful. Establishing routine and standardized measures of the provision of food assistance to these populations can aid in estimating their qualitative and quantitative impacts, while illustrating areas for modifications and cost savings in certain scenarios. Furthermore, the establishment of cohort designs and linkages to measurable interventions and outcomes will make it possible to ask a myriad of questions regarding the appropriateness, cost and patterns of provision of food assistance among heterogeneous pastoralist populations. Collaboration and guidance from humanitarian providers can create novel opportunities to understand the effects that interventions may or may not have on the intended population.

The second important contribution made by this review is the advancement in knowledge regarding the appropriateness of the provision of food assistance to often marginalized and vulnerable pastoralist populations. Although the findings themselves are limited in the quality of their causal claims, they are significant in that they fill a conspicuous gap in the humanitarian evidence literature and represent the first extensive attempt to date to identify, collect and evaluate the provision of food assistance to pastoralist populations. Thus, the illumination of the limited evidence and substantial opportunities for future evaluation and measurement may prove to be the most important finding. The research team encourages leaders in this space to work together to improve the overall quality of data collection and reporting. To this end, we encourage the provision of funds for evaluating programmes retrospectively, using mixed methods and a multidisciplinary approach, the goal of which will be to develop a deeper, more dynamic and more valid understanding of the impacts of food aid during different types of humanitarian crisis across representative populations. 
Figure 4.1: Study characteristics of included publications by author, year, language, study design and methods, population details, humanitarian crisis type and response with food aid among included publications $(n=24)$

\begin{tabular}{|c|c|c|c|c|c|c|c|c|c|c|c|}
\hline Publication & Language & $\begin{array}{l}\text { Research } \\
\text { type }\end{array}$ & $\begin{array}{l}\text { Research } \\
\text { design }\end{array}$ & $\begin{array}{l}\text { Design and } \\
\text { method }\end{array}$ & $\begin{array}{l}\text { Study } \\
\text { period }\end{array}$ & Study aims & Location(s) & $\begin{array}{l}\text { Description of } \\
\text { population(s) }\end{array}$ & $\begin{array}{l}\text { Number } \\
\text { affected }\end{array}$ & Crisis type & $\begin{array}{l}\text { Details of food } \\
\text { aid }\end{array}$ \\
\hline \multicolumn{12}{|c|}{ HORN OF AFRICA } \\
\hline $\begin{array}{l}\text { Taylor } \\
\text { (1983) }\end{array}$ & English & Primary & Observational & $\begin{array}{l}\text { Case study, } \\
\text { quantitative }\end{array}$ & $1980-81$ & \begin{tabular}{|l|} 
To evaluate \\
supplementary \\
feeding programmes \\
(SFPs) functioning in \\
Somali refugee camps
\end{tabular} & Somalia & $\begin{array}{l}\text { Population: Not } \\
\text { reported } \\
\text { Mobility: Nomadic } \\
\text { Gender: Not } \\
\text { reported }\end{array}$ & 40,492 & $\begin{array}{l}\text { Drought } \\
\text { Conflict - } \\
\text { border } \\
\text { dispute } \\
\text { between } \\
\text { Somalia } \\
\text { and } \\
\text { Ethiopia }\end{array}$ & $\begin{array}{l}\text { Aid: } \\
\text { Unconditional } \\
\text { food provision } \\
\text { Provider. } \\
\text { Somali Ministry } \\
\text { of Health } \\
\text { Duration of aid: } \\
1 \text { year }\end{array}$ \\
\hline $\begin{array}{l}\text { Snow } \\
(1984)\end{array}$ & English & Unclear & Unclear & $\begin{array}{l}\text { Case study, } \\
\text { qualitative }\end{array}$ & $\begin{array}{l}\text { Not } \\
\text { reported }\end{array}$ & $\begin{array}{l}\text { To investigate the } \\
\text { best ways to provide } \\
\text { relief to pastoralist } \\
\text { nomads such as the } \\
\text { Turkana and its likely } \\
\text { long-term effects }\end{array}$ & Kenya & $\begin{array}{l}\text { Population: } \\
\text { Turkana } \\
\text { Mobility: Nomadic } \\
\text { Gender. Men and } \\
\text { women }\end{array}$ & $\begin{array}{l}\text { Not } \\
\text { reported }\end{array}$ & Drought & $\begin{array}{l}\text { Aid: } \\
\text { Unconditional } \\
\text { food provision, } \\
\text { food-for-work } \\
\text { Provider. Not } \\
\text { reported } \\
\text { Duration of aid: } \\
\text { Not reported }\end{array}$ \\
\hline $\begin{array}{l}\text { Adams and } \\
\text { Hawksley } \\
\text { (1989) }\end{array}$ & English & Primary & Observational & $\begin{array}{l}\text { Case study, } \\
\text { qualitative }\end{array}$ & $1956-89$ & $\begin{array}{l}\text { To examine Darfur's } \\
\text { experience with relief } \\
\text { and development } \\
\text { institutions in the } \\
\text { process of post- } \\
\text { drought recovery }\end{array}$ & Sudan & $\begin{array}{l}\text { Population: Not } \\
\text { reported } \\
\text { Mobility: } \\
\text { Agriculturalist, } \\
\text { agropastoralist, } \\
\text { nomadic } \\
\text { Gender. Not } \\
\text { reported }\end{array}$ & 3-4 million & $\begin{array}{l}\text { Drought } \\
\text { Famine }\end{array}$ & $\begin{array}{l}\text { Aid: } \\
\text { Unconditional } \\
\text { food provision } \\
\text { Provider. } \\
\text { United Nations, } \\
\text { government, } \\
\text { NGOs } \\
\text { (unnamed) } \\
\text { Duration of aid: } \\
2 \text { years }\end{array}$ \\
\hline $\begin{array}{l}\text { Ngunjiri } \\
\text { (1989) }\end{array}$ & English & Primary & Observational & $\begin{array}{l}\text { Case study, } \\
\text { qualitative }\end{array}$ & 1983-89 & $\begin{array}{l}\text { To describe 'two } \\
\text { innovative projects } \\
\text { undertaken by Oxfam } \\
\text { in the pastoral areas } \\
\text { of Kenya' }\end{array}$ & Kenya & $\begin{array}{l}\text { Population: Not } \\
\text { reported } \\
\text { Mobility: Not } \\
\text { reported } \\
\text { Gender. Men and } \\
\text { women }\end{array}$ & $\begin{array}{l}\text { Not } \\
\text { reported }\end{array}$ & Drought & $\begin{array}{l}\text { Aid: Food-for- } \\
\text { livestock } \\
\text { exchange } \\
\text { Provider. } \\
\text { Oxfam } \\
\text { Duration of aid: } \\
\text { Not reported }\end{array}$ \\
\hline $\begin{array}{l}\text { Asmarom } \\
\text { (1989) }\end{array}$ & English & Primary & Observational & $\begin{array}{l}\text { Case study, } \\
\text { qualitative }\end{array}$ & $\begin{array}{l}\text { Not } \\
\text { reported }\end{array}$ & \begin{tabular}{|l|} 
To examine 'the \\
patterns of pastoral \\
adaptation to arid \\
environments, how \\
the adaptive \\
processes are \\
affected by extended \\
periods of drought, \\
and what types of \\
development might be \\
appropriate under \\
those conditions' \\
\end{tabular} & Kenya & $\begin{array}{l}\text { Population: } \\
\text { Borana, Gabbra } \\
\text { Mobility: Nomadic } \\
\text { Gender. Not } \\
\text { reported }\end{array}$ & $\begin{array}{l}\text { Not } \\
\text { reported }\end{array}$ & $\begin{array}{l}\text { Drought } \\
\text { Famine }\end{array}$ & $\begin{array}{l}\text { Aid: } \\
\text { Unconditional } \\
\text { food provision } \\
\text { Provider. } \\
\text { Catholic } \\
\text { mission (further } \\
\text { details not } \\
\text { provided) } \\
\text { Duration of aid: } \\
\text { Not reported }\end{array}$ \\
\hline $\begin{array}{l}\text { McCabe } \\
\text { (1990) }\end{array}$ & English & Primary & $\begin{array}{l}\text { Quasi- } \\
\text { experimental }\end{array}$ & $\begin{array}{l}\text { Natural } \\
\text { experiment, } \\
\text { qualitative }\end{array}$ & 1979-81 & $\begin{array}{l}\text { To compare the } \\
\text { pastoral economies of } \\
\text { two groups of Turkana }\end{array}$ & Kenya & $\begin{array}{l}\text { Population: } \\
\text { Ngilukumong, } \\
\text { Ngiyapakuno, } \\
\text { Ngikamatak, } \\
\text { Ngibocheros of } \\
\text { Turkana } \\
\text { Mobility: Nomadic } \\
\text { Gender: Not } \\
\text { reported }\end{array}$ & $\begin{array}{l}\text { Not } \\
\text { reported }\end{array}$ & Drought & $\begin{array}{l}\text { Aid: } \\
\text { Unconditional } \\
\text { food provision } \\
\text { Provider. Not } \\
\text { reported } \\
\text { Duration of aid: } \\
3 \text { years }\end{array}$ \\
\hline $\begin{array}{l}\text { Farzin } \\
(1991)\end{array}$ & English & Primary & Observational & $\begin{array}{l}\text { Case study, } \\
\text { quantitative }\end{array}$ & $1970-84$ & $\begin{array}{l}\text { To assess whether } \\
\text { the impact of food aid } \\
\text { on Somalia has been } \\
\text { positive or negative }\end{array}$ & Somalia & $\begin{array}{l}\text { Population: Not } \\
\text { reported } \\
\text { Mobility: Not } \\
\text { reported } \\
\text { Gender. Not } \\
\text { reported }\end{array}$ & $\begin{array}{l}\text { Not } \\
\text { reported }\end{array}$ & $\begin{array}{l}\text { Not } \\
\text { reported }\end{array}$ & $\begin{array}{l}\text { Aid: } \\
\text { Unconditional } \\
\text { food provision } \\
\text { Provider. } \\
\text { Multiple (details } \\
\text { not provided) } \\
\text { Duration of aid: } \\
\text { Not provided }\end{array}$ \\
\hline
\end{tabular}




\begin{tabular}{|c|c|c|c|c|c|c|c|c|c|c|c|}
\hline Publication & Language & $\begin{array}{l}\text { Research } \\
\text { type }\end{array}$ & $\begin{array}{l}\text { Research } \\
\text { design }\end{array}$ & $\begin{array}{l}\text { Design and } \\
\text { method }\end{array}$ & $\begin{array}{l}\text { Study } \\
\text { period }\end{array}$ & Study aims & Location(s) & $\begin{array}{l}\text { Description of } \\
\text { population(s) }\end{array}$ & $\begin{array}{l}\text { Number } \\
\text { affected }\end{array}$ & Crisis type & $\begin{array}{l}\text { Details of food } \\
\text { aid }\end{array}$ \\
\hline $\begin{array}{l}\text { Cutler } \\
(1991)\end{array}$ & English & Primary & Observational & $\begin{array}{l}\text { Other, } \\
\text { quantitative }\end{array}$ & 1984-85 & $\begin{array}{l}\text { To compare provision } \\
\text { of food assistance in } \\
\text { Ethiopia and Sudan in } \\
\text { the mid-1980s }\end{array}$ & $\begin{array}{l}\text { Ethiopia, } \\
\text { Sudan }\end{array}$ & $\begin{array}{l}\text { Population: Not } \\
\text { reported } \\
\text { Mobility: Not } \\
\text { reported } \\
\text { Gender: Not } \\
\text { reported }\end{array}$ & $\begin{array}{l}\text { Not } \\
\text { reported }\end{array}$ & Drought & $\begin{array}{l}\text { Aid: Not } \\
\text { reported } \\
\text { Provider. } \\
\text { Multiple (details } \\
\text { not provided) } \\
\text { Duration of aid: } \\
\text { Not reported }\end{array}$ \\
\hline Kilby (1993) & English & Secondary & Other review & $\begin{array}{l}\text { Other, } \\
\text { qualitative }\end{array}$ & $1983-90$ & $\begin{array}{l}\text { To assess the impacts } \\
\text { of food assistance } \\
\text { programmes and an } \\
\text { integrated pastoral } \\
\text { development } \\
\text { programme }\end{array}$ & Sudan & $\begin{array}{l}\text { Population: Not } \\
\text { reported } \\
\text { Mobility: Not } \\
\text { reported } \\
\text { Gender: Not } \\
\text { reported }\end{array}$ & $\begin{array}{l}\text { Not } \\
\text { reported }\end{array}$ & Drought & $\begin{array}{l}\text { Aid: } \\
\text { Unconditional } \\
\text { food aid } \\
\text { Provider. } \\
\text { Oxfam } \\
\text { Duration of aid: } \\
\text { 2-4 years }\end{array}$ \\
\hline Bush (1995) & English & Primary & Observational & $\begin{array}{l}\text { Case study, } \\
\text { mixed }\end{array}$ & 1992-94 & $\begin{array}{l}\text { To evaluate the role of } \\
\text { food assistance in the } \\
\text { context of long-term } \\
\text { drought }\end{array}$ & Kenya & $\begin{array}{l}\text { Population: } \\
\text { Turkana } \\
\text { Mobility: Nomadic } \\
\text { Gender: Not } \\
\text { reported }\end{array}$ & 224,000 & $\begin{array}{l}\text { Drought } \\
\text { Flood }\end{array}$ & $\begin{array}{l}\text { Aid: } \\
\text { Unconditional } \\
\text { food aid } \\
\text { Provider. } \\
\text { Oxfam, World } \\
\text { Vision } \\
\text { Duration of aid: } \\
2 \text { years }\end{array}$ \\
\hline $\begin{array}{l}\text { Buchanan- } \\
\text { Smith and } \\
\text { Barton } \\
(1999)\end{array}$ & English & Primary & Observational & $\begin{array}{l}\text { Case study, } \\
\text { mixed }\end{array}$ & 1996-98 & $\begin{array}{l}\text { To evaluate the } \\
\text { Oxfam Wajir Relief } \\
\text { Programme 1996-98 }\end{array}$ & Kenya & $\begin{array}{l}\text { Population: Not } \\
\text { reported } \\
\text { Mobility: Nomadic } \\
\text { Gender. Men and } \\
\text { women }\end{array}$ & 190,000 & $\begin{array}{l}\text { Drought } \\
\text { Flood }\end{array}$ & $\begin{array}{l}\text { Aid: } \\
\text { Unconditional } \\
\text { food aid } \\
\text { Provider. } \\
\text { Oxfam } \\
\text { Duration of aid: } \\
2 \text { years }\end{array}$ \\
\hline $\begin{array}{l}\text { No author } \\
(2001)\end{array}$ & English & Primary & Observational & $\begin{array}{l}\text { Case study, } \\
\text { quantitative }\end{array}$ & 2000 & & Ethiopia & $\begin{array}{l}\text { Population: } \\
\text { Ethiopian Somalis } \\
\text { Mobility: Not } \\
\text { reported } \\
\text { Gender: Not } \\
\text { reported }\end{array}$ & $\begin{array}{l}\text { Not } \\
\text { reported }\end{array}$ & $\begin{array}{l}\text { Drought } \\
\text { Famine }\end{array}$ & $\begin{array}{l}\text { Aid: Not } \\
\text { reported } \\
\text { Provider. } \\
\text { Multiple NGOs } \\
\text { Duration of aid: } \\
\text { Not reported }\end{array}$ \\
\hline $\begin{array}{l}\text { Pantuliano } \\
(2002)\end{array}$ & English & Secondary & Other review & $\begin{array}{l}\text { Case study, } \\
\text { qualitative }\end{array}$ & $\begin{array}{l}1890 \\
2002\end{array}$ & $\begin{array}{l}\text { To examine the } \\
\text { transformation of the } \\
\text { Beja livelihood system } \\
\text { in recent years in } \\
\text { response to changing } \\
\text { external } \\
\text { circumstances, and } \\
\text { chart how coping } \\
\text { mechanisms have } \\
\text { evolved to become } \\
\text { adaptive strategies }\end{array}$ & Sudan & $\begin{array}{l}\text { Population: } \\
\text { Amar'ar/ Atmaan, } \\
\text { Bishariyyn groups } \\
\text { of the Beja } \\
\text { Mobility: Nomadic } \\
\text { Gender. Men and } \\
\text { women }\end{array}$ & $\begin{array}{l}\text { Not } \\
\text { reported }\end{array}$ & Drought & $\begin{array}{l}\text { Aid: Food-for- } \\
\text { work } \\
\text { Provider. World } \\
\text { Food } \\
\text { Programme } \\
\text { Duration of aid: } \\
\text { Not reported }\end{array}$ \\
\hline $\begin{array}{l}\text { Overseas } \\
\text { Developme } \\
\text { nt Institute } \\
(2006)\end{array}$ & English & Primary & Observational & $\begin{array}{l}\text { Case study, } \\
\text { qualitative }\end{array}$ & 2006 & $\begin{array}{l}\text { To identify critical } \\
\text { gaps in the response } \\
\text { to the drought in the } \\
\text { Greater Horn of Africa }\end{array}$ & $\begin{array}{l}\text { Djibouti, } \\
\text { Eritrea, } \\
\text { Ethiopia, } \\
\text { Kenya, } \\
\text { Somalia }\end{array}$ & $\begin{array}{l}\text { Population: } \\
\text { Pastoralists of } \\
\text { Djibouti, Eritrea, } \\
\text { Ethiopia, Kenya } \\
\text { and Somalia } \\
\text { Mobility: Not } \\
\text { reported } \\
\text { Gender. Not } \\
\text { reported }\end{array}$ & 11 million & Drought & $\begin{array}{l}\text { Aid: Not } \\
\text { reported } \\
\text { Provider. Not } \\
\text { reported } \\
\text { Duration of aid: } \\
\text { Not reported }\end{array}$ \\
\hline $\begin{array}{l}\text { Pantuliano } \\
(2007)\end{array}$ & English & Primary & Observational & $\begin{array}{l}\text { Case study, } \\
\text { qualitative }\end{array}$ & $\begin{array}{l}\text { Mid- } \\
1980 \text { s- } \\
2007\end{array}$ & $\begin{array}{l}\text { To consider the } \\
\text { alternatives to food } \\
\text { assistance in eastern } \\
\text { Sudan }\end{array}$ & Sudan & $\begin{array}{l}\text { Population: Beja, } \\
\text { Rashaida, others } \\
\text { (unidentified) } \\
\text { Mobility: Nomadic, } \\
\text { agropastoralist, } \\
\text { agriculturalist } \\
\text { Gender: Not } \\
\text { reported }\end{array}$ & 3.75 million & Drought & $\begin{array}{l}\text { Aid: } \\
\text { Unconditional } \\
\text { food aid } \\
\text { Provider. WFP } \\
\text { Duration of aid: } \\
20 \text { years }\end{array}$ \\
\hline
\end{tabular}




\begin{tabular}{|c|c|c|c|c|c|c|c|c|c|c|c|}
\hline Publication & Language & $\begin{array}{l}\text { Research } \\
\text { type }\end{array}$ & $\begin{array}{l}\text { Research } \\
\text { design }\end{array}$ & $\begin{array}{l}\text { Design and } \\
\text { method }\end{array}$ & $\begin{array}{l}\text { Study } \\
\text { period }\end{array}$ & Study aims & Location(s) & $\begin{array}{l}\text { Description of } \\
\text { population(s) }\end{array}$ & $\begin{array}{l}\text { Number } \\
\text { affected }\end{array}$ & Crisis type & $\begin{array}{l}\text { Details of food } \\
\text { aid }\end{array}$ \\
\hline $\begin{array}{l}\text { Adow } \\
(2008)\end{array}$ & English & Unclear & Observational & $\begin{array}{l}\text { Case study, } \\
\text { qualitative }\end{array}$ & $\begin{array}{l}\text { Not } \\
\text { reported }\end{array}$ & $\begin{array}{l}\text { Unclear (perhaps to } \\
\text { observe the changes } \\
\text { in pastoralist } \\
\text { livelihoods in Northern } \\
\text { Kenya as a result of } \\
\text { drought and floods) }\end{array}$ & Kenya & $\begin{array}{l}\text { Population: } \\
\text { Pastoralists of } \\
\text { northern Kenya } \\
\text { Mobility: Not } \\
\text { reported } \\
\text { Gender: Not } \\
\text { reported }\end{array}$ & $\begin{array}{l}\text { Not } \\
\text { reported }\end{array}$ & $\begin{array}{l}\text { Drought } \\
\text { Flood }\end{array}$ & $\begin{array}{l}\text { Aid: Not } \\
\text { reported } \\
\text { Provider. Not } \\
\text { reported } \\
\text { Duration of aid: } \\
\text { Not reported }\end{array}$ \\
\hline $\begin{array}{l}\text { Nangulu } \\
(2009)\end{array}$ & English & Primary & Observational & $\begin{array}{l}\text { Case study, } \\
\text { qualitative }\end{array}$ & $1920-95$ & $\begin{array}{l}\text { To analyze food } \\
\text { security and coping } \\
\text { mechanisms in West } \\
\text { Pokot, Kenya }\end{array}$ & Kenya & $\begin{array}{l}\text { Population: Pokot } \\
\text { Mobility: Nomadic } \\
\text { Gender: Men and } \\
\text { women }\end{array}$ & $\begin{array}{l}\text { Not } \\
\text { reported }\end{array}$ & $\begin{array}{l}\text { Drought } \\
\text { Disease } \\
\text { Livestock } \\
\text { raiding }\end{array}$ & $\begin{array}{l}\text { Aid: Not } \\
\text { reported } \\
\text { Provider. } \\
\text { National } \\
\text { government, } \\
\text { WFP, } \\
\text { unidentified } \\
\text { NGOs } \\
\text { Duration of aid: } \\
\text { Not reported }\end{array}$ \\
\hline $\begin{array}{l}\text { Stockton } \\
(2012)\end{array}$ & English & Primary & Observational & $\begin{array}{l}\text { Case study, } \\
\text { mixed }\end{array}$ & $\begin{array}{l}\text { Not } \\
\text { reported }\end{array}$ & $\begin{array}{l}\text { To discuss 'some of } \\
\text { the realities faced by } \\
\text { the } 20 \text { million } \\
\text { pastoralists and the } \\
\text { international agencies } \\
\text { that deliver } \\
\text { emergency and } \\
\text { development } \\
\text { assistance in the } \\
\text { pastoral arc of the } \\
\text { Horn of Africa' }\end{array}$ & Horn of Africa & $\begin{array}{l}\text { Population: } \\
\text { Oromo, Pokot, } \\
\text { Somali, Turkana, } \\
\text { other (unidentified) } \\
\text { Mobility: Nomadic } \\
\text { Gender. Not } \\
\text { reported }\end{array}$ & 20 million & $\begin{array}{l}\text { Drought } \\
\text { Conflict }\end{array}$ & $\begin{array}{l}\text { Aid: Not } \\
\text { reported } \\
\text { Provider. Not } \\
\text { reported } \\
\text { Duration of aid: } \\
\text { Not reported }\end{array}$ \\
\hline $\begin{array}{l}\text { Lekapana } \\
(2013)\end{array}$ & English & Primary & Observational & $\begin{array}{l}\text { Case study, } \\
\text { mixed }\end{array}$ & $\begin{array}{l}\text { Not } \\
\text { reported }\end{array}$ & $\begin{array}{l}\text { To study 'the } \\
\text { socioeconomic effects } \\
\text { of drought on } \\
\text { pastoralists, their } \\
\text { coping and adaptation } \\
\text { strategies, and the } \\
\text { government } \\
\text { interventions in } \\
\text { Loiyangalani Division } \\
\text { of Marsabit County' }\end{array}$ & Kenya & $\begin{array}{l}\text { Population: Not } \\
\text { reported } \\
\text { Mobility: Not } \\
\text { reported } \\
\text { Gender: Not } \\
\text { reported }\end{array}$ & $\begin{array}{l}\text { Not } \\
\text { reported }\end{array}$ & Drought & $\begin{array}{l}\text { Aid: Not } \\
\text { reported } \\
\text { Provider. } \\
\text { Government, } \\
\text { development } \\
\text { partners } \\
\text { (details not } \\
\text { reported) } \\
\text { Duration of aid: } \\
\text { Not reported }\end{array}$ \\
\hline $\begin{array}{l}\text { Bersaglio et } \\
\text { al. (2015) }\end{array}$ & English & Primary & Observational & $\begin{array}{l}\text { Case study, } \\
\text { qualitative }\end{array}$ & 2011-12 & $\begin{array}{l}\text { To contextualize } \\
\text { emergency responses } \\
\text { to famine among } \\
\text { Turkana pastoralists }\end{array}$ & Kenya & $\begin{array}{l}\text { Population: } \\
\text { Turkana } \\
\text { Mobility: Nomadic } \\
\text { Gender. Men and } \\
\text { women }\end{array}$ & 6,000 & Drought & $\begin{array}{l}\text { Aid: } \\
\text { Unconditional } \\
\text { food aid } \\
\text { Provider. } \\
\text { Christian } \\
\text { mission (details } \\
\text { not reported) } \\
\text { Duration of aid: } \\
1 \text { year }\end{array}$ \\
\hline \multicolumn{12}{|c|}{ AFRICA, OTHER } \\
\hline $\begin{array}{l}\text { News24 } \\
(2005)\end{array}$ & English & Primary & Observational & $\begin{array}{l}\text { Other, } \\
\text { qualitative }\end{array}$ & 2005 & & Niger & $\begin{array}{l}\text { Population: } \\
\text { Nigerien } \\
\text { pastoralists } \\
\text { Mobility: Not } \\
\text { reported } \\
\text { Gender: Not } \\
\text { reported }\end{array}$ & 12 million & $\begin{array}{l}\text { Drought } \\
\text { Famine }\end{array}$ & $\begin{array}{l}\text { Aid: } \\
\text { Unconditional } \\
\text { food aid } \\
\text { Provider. } \\
\text { United Nations } \\
\text { Duration of aid: } \\
\text { Not reported }\end{array}$ \\
\hline $\begin{array}{l}\text { Cicalese et } \\
\text { al. (2009) }\end{array}$ & English & Primary & Observational & $\begin{array}{l}\text { Case study, } \\
\text { quantitative }\end{array}$ & 2006-07 & $\begin{array}{l}\text { 'To establish the } \\
\text { nutritional impact of } \\
\text { the food aids } \\
\text { distributed to the } \\
\text { Saharawi population } \\
\text { in view of possible } \\
\text { clinical correlations } \\
\text { with celiac disease' }\end{array}$ & Algeria & $\begin{array}{l}\text { Population: } \\
\text { Saharawis } \\
\text { Mobility: Nomadic } \\
\text { Gender. Not } \\
\text { reported }\end{array}$ & 250,000 & $\begin{array}{l}\text { Conflict - } \\
\text { expulsion } \\
\text { from } \\
\text { Western } \\
\text { Sahara } \\
\text { region }\end{array}$ & $\begin{array}{l}\text { Aid: Not } \\
\text { reported } \\
\text { Provider. Not } \\
\text { reported } \\
\text { Duration of aid: } \\
\text { Not reported }\end{array}$ \\
\hline
\end{tabular}




\begin{tabular}{|c|c|c|c|c|c|c|c|c|c|c|c|}
\hline Publication & Language & $\begin{array}{l}\text { Research } \\
\text { type }\end{array}$ & $\begin{array}{l}\text { Research } \\
\text { design }\end{array}$ & $\begin{array}{l}\text { Design and } \\
\text { method }\end{array}$ & $\begin{array}{l}\text { Study } \\
\text { period }\end{array}$ & Study aims & Location(s) & $\begin{array}{l}\text { Description of } \\
\text { population(s) }\end{array}$ & $\begin{array}{l}\text { Number } \\
\text { affected }\end{array}$ & Crisis type & $\begin{array}{l}\text { Details of food } \\
\text { aid }\end{array}$ \\
\hline \multicolumn{12}{|l|}{ ASIA } \\
\hline $\begin{array}{l}\text { No author } \\
(2002)\end{array}$ & English & Primary & Observational & $\begin{array}{l}\text { Case } \\
\text { control, } \\
\text { quantitative }\end{array}$ & $\begin{array}{l}1999- \\
2001\end{array}$ & $\begin{array}{l}\text { To assess reported } \\
\text { severe psychological } \\
\text { stress, increased } \\
\text { school drop-out rates } \\
\text { and increased } \\
\text { migration of rural } \\
\text { herders into urban } \\
\text { centres }\end{array}$ & Mongolia & $\begin{array}{l}\text { Population: } \\
\text { Mongolian herders } \\
\text { Mobility: Not } \\
\text { reported } \\
\text { Gender: Not } \\
\text { reported }\end{array}$ & 810,000 & Dzud & $\begin{array}{l}\text { Aid: Not } \\
\text { reported } \\
\text { Provider. Not } \\
\text { reported } \\
\text { Duration of aid: } \\
\text { Not reported }\end{array}$ \\
\hline $\begin{array}{l}\text { Fernandez- } \\
\text { Gimenez et } \\
\text { al. (2012) }\end{array}$ & English & Primary & Observational & $\begin{array}{l}\text { Case study, } \\
\text { mixed }\end{array}$ & 2009-10 & $\begin{array}{l}\text { To document } \\
\text { individual and } \\
\text { community } \\
\text { experiences with dzud } \\
\text { and identify the } \\
\text { factors that make } \\
\text { some households and } \\
\text { communities more } \\
\text { vulnerable to dzud } \\
\text { and others less so }\end{array}$ & Mongolia & $\begin{array}{l}\text { Population: } \\
\text { Mongolian herders } \\
\text { Mobility: Nomadic } \\
\text { Gender: Not } \\
\text { reported }\end{array}$ & 769,000 & Dzud & $\begin{array}{l}\text { Aid: } \\
\text { Unconditional } \\
\text { food aid } \\
\text { Provider: Not } \\
\text { reported } \\
\text { Duration of aid: } \\
\text { Not reported }\end{array}$ \\
\hline
\end{tabular}


Figure 4.2: Changes in livelihood strategies and asset and income dynamics

\begin{tabular}{|c|c|c|c|}
\hline Publication & $\begin{array}{l}\text { Type of } \\
\text { intervention }\end{array}$ & $\begin{array}{l}\text { Outcome(s) } \\
\text { measured }\end{array}$ & Description of impact(s) \\
\hline \multicolumn{4}{|l|}{ HORN OF AFRICA } \\
\hline McCabe (1990) & $\begin{array}{l}\text { Unconditional } \\
\text { food aid }\end{array}$ & $\begin{array}{l}\text { Livelihood } \\
\text { strategies }\end{array}$ & $\begin{array}{l}\text { Compared with the nomadic Ngisonyoka of Southern Turkana, those in } \\
\text { the Ngilukumong, Ghiyapakuno, Ngikamatak and Ngibocheros sections } \\
\text { of the northern Turkana witnessed a breakdown of indigenous drought } \\
\text { coping strategies. }\end{array}$ \\
\hline Cutler (1991) & Not reported & $\begin{array}{l}\text { Income } \\
\text { dynamics }\end{array}$ & $\begin{array}{l}\text { Undermining the domestic food economy: grain prices dropped; } \\
\text { labourers failed to migrate where needed to assist with the harvest; and } \\
\text { crops were left unharvested because the market for them became too } \\
\text { weak. }\end{array}$ \\
\hline Kilby (1993) & $\begin{array}{l}\text { Unconditional } \\
\text { food aid }\end{array}$ & $\begin{array}{l}\text { Income } \\
\text { dynamics }\end{array}$ & $\begin{array}{l}\text { The food assistance programmes in Sudan were compared with the } \\
\text { Oxfam restocking project in Kenya (Moris, 1988): 'The results suggest } \\
\text { that it is still far more economic to restock than to provide food aid for } \\
\text { four years.' }\end{array}$ \\
\hline Snow (1984) & $\begin{array}{l}\text { Unconditional } \\
\text { food aid and } \\
\text { food-for-work }\end{array}$ & $\begin{array}{l}\text { Mobility } \\
\text { patterns }\end{array}$ & $\begin{array}{l}\text { Established food-for-work projects leading to a life away from } \\
\text { pastoralism, towards agriculture. A possible shift to a cash crop } \\
\text { economy was also observed. }\end{array}$ \\
\hline Bush (1995) & $\begin{array}{l}\text { Unconditional } \\
\text { food aid }\end{array}$ & $\begin{array}{l}\text { Livelihood } \\
\text { strategies }\end{array}$ & $\begin{array}{l}\text { Food aid led to a strengthening of herd growth while it filled income gaps } \\
\text { among recipients. }\end{array}$ \\
\hline $\begin{array}{l}\text { Buchanan-Smith and } \\
\text { Barton (1999) }\end{array}$ & $\begin{array}{l}\text { Unconditional } \\
\text { food aid }\end{array}$ & $\begin{array}{l}\text { Asset and } \\
\text { income } \\
\text { dynamics }\end{array}$ & $\begin{array}{l}\text { The provision of food aid resulted in a reduction in livestock sales while } \\
\text { reducing overall individual-level and household debt. }\end{array}$ \\
\hline Pantuliano (2002) & Food-for-work & $\begin{array}{l}\text { Livelihood } \\
\text { strategies }\end{array}$ & $\begin{array}{l}\text { Changes in livelihood strategy patterns were observed, in particular a } \\
\text { weakening of the Beja livelihood system. }\end{array}$ \\
\hline $\begin{array}{l}\text { Overseas } \\
\text { Development Institute } \\
(2006)\end{array}$ & Not reported & $\begin{array}{l}\text { Livelihood } \\
\text { strategies }\end{array}$ & $\begin{array}{l}\text { Although limited details were provided on the impact of food aid, the } \\
\text { authors noted: 'The humanitarian response to the crisis in the Greater } \\
\text { Horn of Africa has done very little, to date, to protect livelihoods.' }\end{array}$ \\
\hline Nangulu (2009) & Not reported & $\begin{array}{l}\text { Livelihood } \\
\text { strategies }\end{array}$ & $\begin{array}{l}\text { Patterns in livelihood strategies have been substantially undermined by } \\
\text { the receipt of food aid. }\end{array}$ \\
\hline Bersaglio et al. (2015) & $\begin{array}{l}\text { Unconditional } \\
\text { food aid }\end{array}$ & $\begin{array}{l}\text { Livelihood } \\
\text { strategies }\end{array}$ & $\begin{array}{l}\text { Livelihood patterns modified in response to food aid, including the } \\
\text { creation of new spaces for community collaboration. However, this has } \\
\text { also contributed to the movement away from pastoralism. }\end{array}$ \\
\hline
\end{tabular}


Figure 4.3: Mobility patterns

\begin{tabular}{|c|c|c|c|}
\hline Publication & $\begin{array}{l}\text { Type of } \\
\text { intervention }\end{array}$ & $\begin{array}{l}\text { Reported } \\
\text { impact(s) }\end{array}$ & Description of impact(s) \\
\hline \multicolumn{4}{|l|}{ HORN OF AFRICA } \\
\hline Snow (1984) & $\begin{array}{l}\text { Unconditional } \\
\text { food aid and } \\
\text { food-for-work }\end{array}$ & $\begin{array}{l}\text { Mobility } \\
\text { patterns }\end{array}$ & $\begin{array}{l}\text { Established food-for-work projects leading to a life away from } \\
\text { pastoralism, towards agriculture. A possible shift to a cash crop } \\
\text { economy was also observed. }\end{array}$ \\
\hline Ngunjiri (1989) & $\begin{array}{l}\text { Unconditional } \\
\text { food aid }\end{array}$ & $\begin{array}{l}\text { Mobility } \\
\text { patterns }\end{array}$ & $\begin{array}{l}\text { The provision of food aid contributed to internal distribution of both } \\
\text { assets and responsibilities: 'Stock owners tended to divide their herds in } \\
\text { two in response to the drought. Women, children, and older members of } \\
\text { the household were often left with the milk herd near centers where relief } \\
\text { was likely to be provided. The men often moved the remainder of the } \\
\text { herd in search of better grazing in areas distant from the center. Though } \\
\text { this meant that the project tended to reach the most vulnerable members } \\
\text { of the household, it also meant that much of the stock put forward to } \\
\text { slaughter was female stock, which would have better been retained for } \\
\text { rebuilding the herd after the drought.' }\end{array}$ \\
\hline McCabe (1990) & $\begin{array}{l}\text { Unconditional } \\
\text { food aid }\end{array}$ & $\begin{array}{l}\text { Mobility } \\
\text { patterns }\end{array}$ & $\begin{array}{l}\text { The attraction of free food influenced traditional patterns of movement } \\
\text { for many individual herd-owners. If members of the family were receiving } \\
\text { food aid, there was a strong incentive for the herd-owner to try to remain } \\
\text { near the relief centre. Once the new rules requiring whole families to } \\
\text { apply for food aid were instituted, this became a necessity. Since the } \\
\text { environment close to the settlements was rapidly becoming denuded, } \\
\text { livestock which, in many instances, were already stressed were forced to } \\
\text { forage on sparser and less nutritious plants than they would have away } \\
\text { from the settlements. This practice inevitably led to livestock losses } \\
\text { through starvation or disease. Thus the famine relief centres were, to } \\
\text { some extent, creating their own clients. }\end{array}$ \\
\hline Kilby (1993) & $\begin{array}{l}\text { Unconditional } \\
\text { food aid }\end{array}$ & $\begin{array}{l}\text { Mobility } \\
\text { patterns }\end{array}$ & $\begin{array}{l}\text { As a result of food aid, those from the Red Sea Hills had increased rates } \\
\text { of sedentarization. }\end{array}$ \\
\hline Pantuliano (2002) & Food-for-work & $\begin{array}{l}\text { Mobility } \\
\text { patterns }\end{array}$ & $\begin{array}{l}\text { Food aid contributed to increased sedentarization and urban drift among } \\
\text { recipients. }\end{array}$ \\
\hline Pantuliano (2007) & $\begin{array}{l}\text { Unconditional } \\
\text { food aid }\end{array}$ & $\begin{array}{l}\text { Mobility } \\
\text { patterns }\end{array}$ & Sedentarization increased as a result of food aid. \\
\hline Adow (2008) & Food aid & $\begin{array}{l}\text { Mobility } \\
\text { patterns }\end{array}$ & $\begin{array}{l}\text { Movement patterns changed in response to food aid: 'Many move near } \\
\text { urban centres to seek emergency food aid.' }\end{array}$ \\
\hline Stockton (2012) & Not reported & $\begin{array}{l}\text { Mobility } \\
\text { patterns }\end{array}$ & $\begin{array}{l}\text { Through the receipt of food aid, populations are reported to be } \\
\text { increasingly sedentary. Although sedentarization is claimed to be the } \\
\text { consequence of food aid, it may be more a result of the development of } \\
\text { water resources, which has taken place alongside the provision of food } \\
\text { aid. }\end{array}$ \\
\hline Bersaglio et al. (2015) & $\begin{array}{l}\text { Unconditional } \\
\text { food aid }\end{array}$ & $\begin{array}{l}\text { Mobility } \\
\text { patterns }\end{array}$ & $\begin{array}{l}\text { Livelihood patterns modified in response to food aid have contributed to } \\
\text { the movement away from pastoralism. }\end{array}$ \\
\hline
\end{tabular}


Figure 4.4: Access, use and dependency on food aid

\begin{tabular}{|c|c|c|c|}
\hline Publication & $\begin{array}{l}\text { Type of } \\
\text { intervention }\end{array}$ & $\begin{array}{l}\text { Outcome(s) } \\
\text { measured }\end{array}$ & Description of impact(s) \\
\hline \multicolumn{4}{|l|}{ HORN OF AFRICA } \\
\hline Snow (1984) & $\begin{array}{l}\text { Unconditional } \\
\text { food aid and } \\
\text { food-for-work }\end{array}$ & $\begin{array}{l}\text { Use of food } \\
\text { assistance }\end{array}$ & $\begin{array}{l}\text { Once food aid was implemented, there was an 'increase in alcoholism } \\
\text { due to distillation of corn, intended for relief, by people with adequate } \\
\text { food supplies who set up stills'. }\end{array}$ \\
\hline Farzin (1991) & $\begin{array}{l}\text { Unconditional } \\
\text { food aid }\end{array}$ & Dependency & $\begin{array}{l}\text { The provision of food aid led to dependence upon its existence while } \\
\text { having a disincentive effect on the domestic food supply. }\end{array}$ \\
\hline Nangulu (2009) & Not reported & Dependency & $\begin{array}{l}\text { Food aid may lead to dependence and enhance poverty among } \\
\text { recipients. }\end{array}$ \\
\hline Adow (2008) & Not reported & Dependency & $\begin{array}{l}\text { Pastoralists in Northern Kenya are almost entirely dependent on } \\
\text { emergency food aid. }\end{array}$ \\
\hline Lekapana (2013) & Not reported & $\begin{array}{l}\text { Dependency } \\
\text { Access to } \\
\text { food }\end{array}$ & $\begin{array}{l}\text { 'Successive drought episodes have forced pastoral communities to rely } \\
\text { on emergency food aid, which has reinforced the cycle of dependency.' } \\
\text { Although food aid was offered to all, unequal distribution of available } \\
\text { goods was reported. }\end{array}$ \\
\hline \multicolumn{4}{|l|}{ AFRICA, OTHER } \\
\hline Cicalese et al. (2009) & Not reported & $\begin{array}{l}\text { Access to } \\
\text { food }\end{array}$ & $\begin{array}{l}\text { Food aid provided was reported to be insufficient and unbalanced, } \\
\text { leading to widespread malnutrition among the recipient population. }\end{array}$ \\
\hline \multicolumn{4}{|l|}{ ASIA } \\
\hline $\begin{array}{l}\text { Fernandez-Gimenez } \\
\text { et al. (2012) }\end{array}$ & $\begin{array}{l}\text { Unconditional } \\
\text { food aid }\end{array}$ & Dependency & $\begin{array}{l}\text { Food aid may have created dependency among recipients: 'Relief aid } \\
\text { that helps prevent loss of life, suffering, and impoverishment in the short- } \\
\text { term may contribute to long-term dependence syndromes, social } \\
\text { disparities, and lack of initiatives on the part of both herders and local } \\
\text { government.' }\end{array}$ \\
\hline
\end{tabular}

Figure 4.5: Gender and health

\begin{tabular}{|c|c|c|c|}
\hline Publication & $\begin{array}{l}\text { Type of } \\
\text { intervention }\end{array}$ & $\begin{array}{l}\text { Reported } \\
\text { impact(s) }\end{array}$ & Description of impact(s) \\
\hline \multicolumn{4}{|l|}{ HORN OF AFRICA } \\
\hline Taylor (1983) & $\begin{array}{l}\text { Unconditional } \\
\text { food aid }\end{array}$ & Health & $\begin{array}{l}\text { Children enrolled in food programmes gained weight over the course of } \\
\text { access to food relief. }\end{array}$ \\
\hline Kilby (1993) & $\begin{array}{l}\text { Unconditional } \\
\text { food aid }\end{array}$ & Health & Food aid had little positive effect on human mortality levels. \\
\hline Bush (1995) & $\begin{array}{l}\text { Unconditional } \\
\text { food aid }\end{array}$ & Health & There was a decline in rates of childhood malnutrition. \\
\hline $\begin{array}{l}\text { Buchanan-Smith and } \\
\text { Barton (1999) }\end{array}$ & $\begin{array}{l}\text { Unconditional } \\
\text { food aid }\end{array}$ & Health & Rates of malnutrition decreased during the provision of food aid. \\
\hline No author (2001) & Not reported & $\begin{array}{l}\text { Health } \\
\text { Gender } \\
\text { roles }\end{array}$ & $\begin{array}{l}\text { Health was substantially impacted through food aid: 'Even though food } \\
\text { aid and feeding centers are a priority during famine, attracting a large } \\
\text { concentration of susceptible persons to feeding centers may increase } \\
\text { transmission of infectious diseases such as measles and diarrhea.' } \\
\text { Gender roles were impacted by the provision and receipt of food aid. } \\
\text { There was a growing tendency for young Turkana women to seek } \\
\text { alternatives to nomadic lifestyles. }\end{array}$ \\
\hline Bersaglio et al. (2015) & $\begin{array}{l}\text { Unconditional } \\
\text { food aid }\end{array}$ & Well-being & $\begin{array}{l}\text { A reduction in anxiety, improvement of living standards and enhanced } \\
\text { spirituality were observed with food aid receipt. }\end{array}$ \\
\hline \multicolumn{4}{|l|}{ ASIA } \\
\hline No author (2002) & Not reported & Health & $\begin{array}{l}\text { Compared with those herders in districts only slightly or not affected: } \\
\text { 'Relief efforts to distribute food to affected areas might have lessened } \\
\text { the nutritional impact of livestock losses among herders and their } \\
\text { families.' }\end{array}$ \\
\hline
\end{tabular}


Figure 4.6: Changes in social relations

\begin{tabular}{|c|c|c|c|}
\hline Publication & $\begin{array}{l}\text { Type of } \\
\text { intervention }\end{array}$ & $\begin{array}{l}\text { Reported } \\
\text { impact(s) }\end{array}$ & Description of impact(s) \\
\hline \multicolumn{4}{|l|}{ HORN OF AFRICA } \\
\hline Snow (1984) & $\begin{array}{l}\text { Unconditional } \\
\text { food aid and } \\
\text { food-for-work }\end{array}$ & $\begin{array}{l}\text { Social } \\
\text { relations }\end{array}$ & $\begin{array}{l}\text { Food aid may have led to the creation of new power structures and } \\
\text { power brokers who challenged the authority of and respect given to } \\
\text { elders. Furthermore, greater concentration of people was observed in } \\
\text { camps. }\end{array}$ \\
\hline Asmarom (1989) & $\begin{array}{l}\text { Unconditional } \\
\text { food aid }\end{array}$ & $\begin{array}{l}\text { Social } \\
\text { relations }\end{array}$ & $\begin{array}{l}\text { Demoralization of the community receiving food assistance was } \\
\text { observed: 'It is the closest thing to an Ik type of non-community that I } \\
\text { ever observed in the Boran country.9 }\end{array}$ \\
\hline Bush (1995) & $\begin{array}{l}\text { Unconditional } \\
\text { food aid }\end{array}$ & $\begin{array}{l}\text { Social } \\
\text { relations }\end{array}$ & Food aid led to a strengthening of social networks. \\
\hline Pantuliano (2002) & Food-for-work & $\begin{array}{l}\text { Social } \\
\text { relations }\end{array}$ & $\begin{array}{l}\text { Aid distribution created a new class of 'food shaikhs', which brought } \\
\text { about a modification of the existing social structure and the traditional } \\
\text { inter-diwab (lineage) dynamics founded on exchange of resources and } \\
\text { reciprocity. }\end{array}$ \\
\hline
\end{tabular}

Figure 4.7: Security and governance

\begin{tabular}{|l|l|l|l|}
\hline Publication & $\begin{array}{l}\text { Type of } \\
\text { intervention }\end{array}$ & $\begin{array}{l}\text { Reported } \\
\text { impact(s) }\end{array}$ & Description of impact(s) \\
\hline HORN OF AFRICA & $\begin{array}{l}\text { Unconditional } \\
\text { food aid and } \\
\text { food-for-work }\end{array}$ & Government & $\begin{array}{l}\text { Greater and increasing power of the Kenyan state and its ability to } \\
\text { control the Turkana were observed through the provision of food aid. }\end{array}$ \\
\hline $\begin{array}{l}\text { Adams and Hawksley (1984) } \\
\text { (1989) }\end{array}$ & $\begin{array}{l}\text { Unconditional } \\
\text { food aid }\end{array}$ & $\begin{array}{l}\text { Security } \\
\text { conditions }\end{array}$ & $\begin{array}{l}\text { During the crisis in Darfur, food aid by non-governmental intervention } \\
\text { was widely lauded to have 'saved a great many lives during the } \\
\text { emergency'. }\end{array}$ \\
\hline Pantuliano (2007) & $\begin{array}{l}\text { Unconditional } \\
\text { food aid }\end{array}$ & $\begin{array}{l}\text { Mobility } \\
\text { patterns }\end{array}$ & $\begin{array}{l}\text { Sedentarization increased as a result of food aid, not only leading to a } \\
\text { strengthening of internal political divisions but also establishing power } \\
\text { brokers. }\end{array}$ \\
\hline
\end{tabular}

\footnotetext{
${ }^{9}$ Asmarom alludes to Turnbull's (1974) controversial study of the lk of northern Karamoja in Uganda, in which he details the alleged disintegration of their society following the supposed destruction of their hunting-based livelihood system.
} 


\section{Figure 4.8: Assessment of the strength of evidence}

Abbreviations and symbols: $\mathrm{Y}$ - yes, $\mathrm{N}-$ no, UN - unclear, $\rightarrow-$ moderate strength of evidence, $\downarrow-$ low strength of evidence

\begin{tabular}{|c|c|c|c|c|c|c|c|c|c|c|c|c|c|c|c|c|c|}
\hline Publication & Doe & he s & udy... & & & & & & & & & & & & & & \\
\hline & 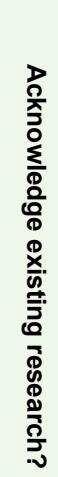 & 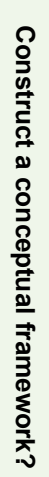 & 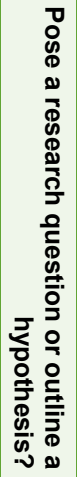 & 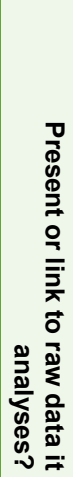 & 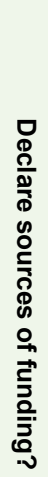 & 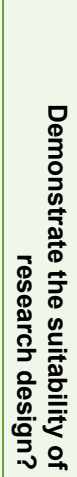 & 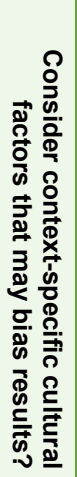 & 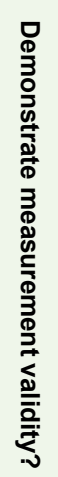 & 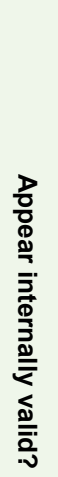 & 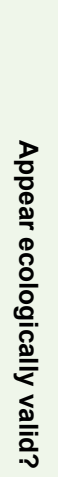 & 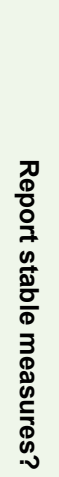 & 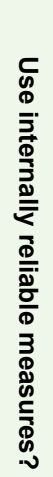 & 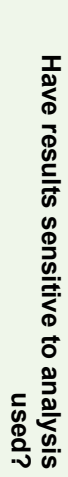 & 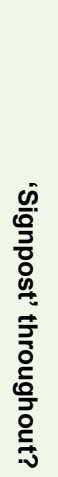 & 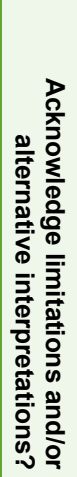 & 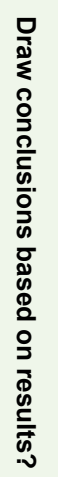 & 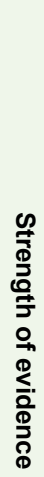 \\
\hline Taylor (1983) & $\mathrm{Y}$ & $\mathrm{Y}$ & $\mathrm{Y}$ & Y & $\mathrm{N}$ & $\mathrm{N}$ & $\mathrm{N}$ & UN & UN & UN & UN & UN & UN & $\mathrm{Y}$ & $\mathrm{N}$ & Y & $\rightarrow$ \\
\hline Snow (1984) & $\mathrm{Y}$ & Y & $\mathrm{Y}$ & $\mathrm{N}$ & $\mathrm{N}$ & $\mathrm{N}$ & $\mathrm{N}$ & $\mathrm{N}$ & UN & UN & UN & UN & UN & $\mathrm{Y}$ & $\mathrm{N}$ & $\mathrm{Y}$ & $\downarrow$ \\
\hline Adams and Hawksley (1989) & $\mathrm{Y}$ & $\mathrm{Y}$ & $\mathrm{N}$ & $\mathrm{N}$ & $\mathrm{N}$ & $\mathrm{N}$ & $\mathrm{N}$ & $\mathrm{N}$ & UN & UN & UN & UN & UN & $\mathrm{Y}$ & $\mathrm{N}$ & $\mathrm{Y}$ & $\downarrow$ \\
\hline Ngunjiri (1989) & $\mathrm{N}$ & $\mathrm{N}$ & $\mathrm{N}$ & Y & $\mathrm{N}$ & $\mathrm{N}$ & $\mathrm{N}$ & $\mathrm{N}$ & UN & UN & UN & UN & UN & $\mathrm{Y}$ & $\mathrm{N}$ & UN & $\downarrow$ \\
\hline Asmarom (1989) & $\mathrm{Y}$ & $Y$ & $\mathrm{Y}$ & Y & $\mathrm{N}$ & $\mathrm{N}$ & $\mathrm{N}$ & $\mathrm{N}$ & UN & UN & UN & UN & UN & $\mathrm{Y}$ & $\mathrm{N}$ & Y & $\rightarrow$ \\
\hline McCabe (1990) & $\mathrm{Y}$ & $\mathrm{Y}$ & $Y$ & Y & $\mathrm{N}$ & $\mathrm{N}$ & $\mathrm{N}$ & $\mathrm{N}$ & UN & UN & UN & UN & UN & $Y$ & $\mathrm{~N}$ & $\mathrm{Y}$ & $\rightarrow$ \\
\hline Farzin (1991) & $\mathrm{Y}$ & $Y$ & $\mathrm{Y}$ & $\mathrm{Y}$ & $\mathrm{N}$ & $\mathrm{N}$ & $\mathrm{N}$ & UN & UN & UN & UN & UN & UN & $\mathrm{Y}$ & $\mathrm{N}$ & Y & $\rightarrow$ \\
\hline Cutler (1991) & $\mathrm{Y}$ & $Y$ & $\mathrm{Y}$ & $\mathrm{N}$ & $\mathrm{N}$ & $\mathrm{N}$ & $\mathrm{N}$ & $\mathrm{N}$ & UN & UN & UN & UN & UN & $Y$ & $\mathrm{~N}$ & $\mathrm{Y}$ & $\downarrow$ \\
\hline Kilby (1993) & $\mathrm{Y}$ & $Y$ & $\mathrm{Y}$ & $\mathrm{Y}$ & $\mathrm{N}$ & $\mathrm{N}$ & $\mathrm{N}$ & $\mathrm{N}$ & UN & UN & UN & UN & UN & $\mathrm{Y}$ & $\mathrm{N}$ & Y & $\downarrow$ \\
\hline Bush (1995) & $\mathrm{Y}$ & $Y$ & $\mathrm{Y}$ & $\mathrm{Y}$ & $\mathrm{N}$ & $\mathrm{N}$ & $\mathrm{N}$ & UN & UN & UN & UN & UN & UN & $\mathrm{Y}$ & $\mathrm{N}$ & $\mathrm{Y}$ & $\rightarrow$ \\
\hline $\begin{array}{l}\text { Buchanan-Smith and Barton } \\
\text { (1999) }\end{array}$ & $Y$ & $Y$ & Y & $Y$ & $Y$ & $\mathrm{~N}$ & $\mathrm{~N}$ & $\mathrm{~N}$ & UN & UN & UN & UN & UN & Y & $\mathrm{N}$ & $\mathrm{Y}$ & $\rightarrow$ \\
\hline No author (2001) & $\mathrm{N}$ & $\mathrm{Y}$ & $\mathrm{N}$ & $Y$ & $\mathrm{~N}$ & $\mathrm{~N}$ & $\mathrm{~N}$ & UN & UN & UN & UN & UN & UN & $\mathrm{Y}$ & $\mathrm{N}$ & Y & $\rightarrow$ \\
\hline Pantuliano (2002) & $Y$ & $Y$ & $\mathrm{Y}$ & $Y$ & $\mathrm{~N}$ & & $\mathrm{~N}$ & $\mathrm{~N}$ & UN & UN & UN & UN & UN & Y & $\mathrm{N}$ & Y & $\rightarrow$ \\
\hline No author (2002) & $\mathrm{N}$ & $Y$ & $\mathrm{~N}$ & $Y$ & $\mathrm{~N}$ & $\mathrm{~N}$ & $\mathrm{~N}$ & UN & UN & UN & UN & UN & UN & $Y$ & $\mathrm{~N}$ & $\mathrm{Y}$ & $\rightarrow$ \\
\hline News24 (2005) & $\mathrm{N}$ & $\mathrm{N}$ & $\mathrm{N}$ & $\mathrm{N}$ & $\mathrm{N}$ & $\mathrm{N}$ & $\mathrm{N}$ & $\mathrm{N}$ & UN & UN & UN & UN & UN & $\mathrm{N} / \mathrm{A}$ & $\mathrm{N}$ & $\mathrm{N} / \mathrm{A}$ & $\downarrow$ \\
\hline $\begin{array}{l}\text { Overseas Development } \\
\text { Institute (2006) }\end{array}$ & $\mathrm{Y}$ & $Y$ & $\mathrm{Y}$ & $\mathrm{N}$ & $\mathrm{N}$ & $\mathrm{N}$ & $\mathrm{N}$ & $\mathrm{N}$ & UN & UN & UN & UN & UN & $\mathrm{Y}$ & $\mathrm{N}$ & UN & $\downarrow$ \\
\hline Pantuliano (2007) & $\mathrm{Y}$ & $Y$ & $\mathrm{Y}$ & Y & $\mathrm{N}$ & $\mathrm{N}$ & $\mathrm{N}$ & $\mathrm{N}$ & UN & UN & UN & UN & UN & $\mathrm{Y}$ & $\mathrm{N}$ & Y & $\rightarrow$ \\
\hline Adow (2008) & $\mathrm{N}$ & $\mathrm{N}$ & $\mathrm{N}$ & $\mathrm{N}$ & $\mathrm{N}$ & $\mathrm{N}$ & $\mathrm{N}$ & $\mathrm{N}$ & UN & UN & UN & UN & UN & $\mathrm{N} / \mathrm{A}$ & $\mathrm{N}$ & $\mathrm{N}$ & $\downarrow$ \\
\hline Nangulu (2009) & $\mathrm{Y}$ & $\mathrm{Y}$ & $\mathrm{Y}$ & Y & $\mathrm{N}$ & $\mathrm{N}$ & $\mathrm{N}$ & $\mathrm{N}$ & UN & UN & UN & UN & UN & $\mathrm{Y}$ & $\mathrm{N}$ & $\mathrm{Y}$ & $\downarrow$ \\
\hline Cicalese et al. (2009) & $\mathrm{N}$ & $Y$ & Y & Y & $\mathrm{N}$ & $\mathrm{N}$ & $\mathrm{N}$ & $\mathrm{N}$ & UN & UN & UN & UN & UN & $\mathrm{N} / \mathrm{A}$ & $\mathrm{N}$ & Y & $\rightarrow$ \\
\hline $\begin{array}{l}\text { Fernandez-Gimenez et al. } \\
\text { (2012) }\end{array}$ & $\mathrm{Y}$ & $Y$ & $\mathrm{Y}$ & $Y$ & $\mathrm{~N}$ & $\mathrm{~N}$ & $\mathrm{~N}$ & UN & UN & UN & UN & UN & UN & $\mathrm{Y}$ & $\mathrm{N}$ & $Y$ & $\rightarrow$ \\
\hline Stockton (2012) & $\mathrm{N}$ & $\mathrm{N}$ & Y & $\mathrm{N}$ & $\mathrm{N}$ & $\mathrm{N}$ & $\mathrm{N}$ & $\mathrm{N}$ & UN & UN & UN & UN & UN & $\mathrm{Y}$ & $\mathrm{N}$ & UN & $\downarrow$ \\
\hline Lekapana (2013) & $\mathrm{Y}$ & Y & $\mathrm{Y}$ & Y & $\mathrm{N}$ & $\mathrm{N}$ & $\mathrm{N}$ & $\mathrm{N}$ & UN & UN & UN & UN & UN & $\mathrm{Y}$ & $\mathrm{Y}$ & UN & $\downarrow$ \\
\hline Bersaglio et al. (2015) & $Y$ & $Y$ & $\mathrm{Y}$ & Y & $\mathrm{N}$ & $\mathrm{N}$ & $\mathrm{N}$ & $\mathrm{N}$ & UN & UN & UN & UN & UN & $\mathrm{Y}$ & $\mathrm{N}$ & Y & $\rightarrow$ \\
\hline
\end{tabular}




\section{APPENDIX 1: DATABASE SEARCH STRATEGY STRINGS}

\section{Ovid Medline $₫ 1946$ to May Week 4 2016, Ovid Medline $₫$ In- Process and other non-indexed citations 1 June 2016}

\section{Search strategy}

\begin{tabular}{|c|c|c|}
\hline \# & Searches & Results \\
\hline 1 & exp Disasters/pc, mt [Prevention \& Control, Methods] & 2,285 \\
\hline 2 & 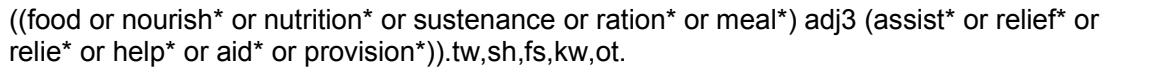 & 6,749 \\
\hline 3 & relief work/ or food assistance/ & 3,924 \\
\hline 4 & (in-kind* adj3 (food* or nutrition* or meal* or nourish* or ration*)).tw,sh,fs,kw,ot. & 23 \\
\hline 5 & (in-kind adj3 (assist ${ }^{*}$ or aid $\left.{ }^{*}\right)$ ).tw,sh,fs,kw,ot. & 13 \\
\hline 6 & (food adj3 (distribut* or work* or asset $\left.{ }^{*}\right)$ ).tw,sh,fs,kw,ot. & 2,592 \\
\hline 7 & $\begin{array}{l}\text { (humanitarian* adj3 (relie* or aid* or intervention* or assist* or help* or } \\
\text { interven*)).tw,sh,fs,kw,ot. }\end{array}$ & 767 \\
\hline 8 & International Cooperation/ & 40,987 \\
\hline 9 & (humanitarian adj3 (mission* or coopera* or co-op*)).tw,sh,fs,kw,ot. & 239 \\
\hline 10 & (relief adj3 (work* or program* or assist* or co-op* or cooper* or initiativ*)).tw,sh,fs,kw,ot. & 715 \\
\hline 11 & $\begin{array}{l}\text { (international adj3 (cooperat* or co-op* or assist* or relie* or aid* or help* or } \\
\left.\text { aid }^{*}\right) \text { ).tw,sh,fs,kw,ot. }\end{array}$ & 5,106 \\
\hline 12 & or/1-11 [ Intervention] & 59,839 \\
\hline 13 & $\begin{array}{l}\text { ((cattle or sheep or cow or mammal* or livestock or live-stock or animal }{ }^{*} \text { or llama* or yak* or } \\
\left.\text { goat }^{*} \text { or } \text { camel }^{*}\right) \text { adj3 husbandr }{ }^{*} . t i, a b, f s, \text { sh,kw,ot,hw. }\end{array}$ & 18,209 \\
\hline 14 & pastoral*.tw,sh,fs,kw,ot,hw. & 5151 \\
\hline 15 & Animal Husbandry/ & 17,119 \\
\hline 16 & exp Agriculture/ & 69,832 \\
\hline 17 & limit 16 to yr="1966 - 1975" & 2,748 \\
\hline 18 & Animals/ & $5,889,534$ \\
\hline 19 & animals, domestic/ or livestock/ & 16,160 \\
\hline 20 & ${\text { agr*-pastoral }{ }^{*} . t w, s h, f s, k w, o t .}$ & 116 \\
\hline 21 & (agr* adj3 pastoral*).tw,sh,fs,kw,ot,hw. & 233 \\
\hline 22 & $\begin{array}{l}\left(\left(\text { nomad }^{*} \text { or transhuman* or itineran* or migrat }{ }^{*}\right) \text { adj3 } \text { (livelihood* }^{*} \text { or farm }^{*} \text { or societ* or group* }\right. \\
\text { or lifestyle)).tw,hw,fs,sh,kw,ot. }\end{array}$ & 1,457 \\
\hline 23 & "Transients and Migrants"/ & 9,140 \\
\hline 24 & or/13-23 & $5,933,380$ \\
\hline 25 & 12 and 24 & 5,950 \\
\hline 26 & limit 25 to yr="1967 -Current" & 5,902 \\
\hline
\end{tabular}




\section{CAB Abstracts 1973 to 2016 Week 20}

\section{Results: 327}

(((mammal ${ }^{*}$ or vertebrate ${ }^{*}$ or cattle* or sheep* or goat $^{*}$ or camel ${ }^{*}$ or yak ${ }^{*}$ or llama* or animal ${ }^{*}$ or chordata* or livestock or live-stock* ${ }^{*}$ adj3 husbandr*).mp,sh,ot. or pastoral ${ }^{*}$.mp,sh,ot or (agr* adj3 pastoral ${ }^{*}$ ).mp,sh, ot OR agr*-pastoral ${ }^{*}$.mp, sh, ot or pastoralism/ or agropastoral systems/ or silvopastoral systems/ OR animal husbandry/ or livestock farming/ or ((nomad* or transhuman* or itineran* or migrat ${ }^{*}$ ) adj3 (livelihood* or farm $^{*}$ or societ ${ }^{*}$ or group* or lifestyle)).mp,sh,ot. or ((cattle or sheep or cow or mammal ${ }^{*}$ or livestock or live-stock or animal $^{*}$ or llama* or yak ${ }^{*}$ or goat* ${ }^{*}$ or camel $\left.{ }^{*}\right)$ adj3 husbandr $\left.{ }^{*}\right)$.mp,sh,ot.) and (((food or nourish ${ }^{*}$ or nutrition* or sustenance or ration* or meal $\left.{ }^{*}\right)$ adj3 (assist* ${ }^{*}$ or relief* or relie* or help* or aid* or provision*)).mp,ot,sh. or (food adj3 (distribut* or work* or asset*)).mp,ot,sh. or exp food aid/ or emergency relief/ or (humanitarian adj3 (mission* or coopera* or co$\left.\mathrm{op}^{*}\right)$ ).mp,sh,ot. or (relief adj3 (work* or program* or assist* or co-op* or cooper* or initiativ $\left.{ }^{*}\right)$ ).mp,sh,ot. or (international adj3 (cooperat* or co-op* or assist* or relie* or aid* or help* or aid*)).mp,sh,ot. OR (in-kind adj3 (assist* or aid*)).mp,sh,ot. or (humanitarian* adj3 (relie* or aid* or intervention* or assist* or help* or interven*)).mp,sh,ot. or (in-kind* adj3 (food ${ }^{*}$ or nutrition* or meal* or nourish* or ration*)).mp,sh,ot.)

\section{LILACS}

\section{Results: 4142}

(tw:(livestock* OR pastoral* OR agro-pastoral* OR "animal husbandr"” OR nomad* OR transhuman*)) AND (tw:(relief* OR crisis OR aid* OR in-kind OR "food assist" OR humanitarian OR interven* OR "food distribution*"))

\section{Web of Science databases (same string for both databases)}

\section{BIOSIS}

Results: 726

\section{Web of Science core collection}

\section{Results: $\mathbf{3 , 0 8 4}$}

TOPIC: ((mammal ${ }^{*}$ or vertebrate* or cattle* or sheep* or goat* or camel $^{*}$ or yak ${ }^{*}$ or llama* or animal $^{*}$ or chordata* or livestock or live-stock*) NEAR/3 husbandr*) OR TOPIC: (nomad* or transhuman* or itineran* or migrat* OR pastoral ${ }^{*}$ OR agr*-pastoral*) AND TOPIC: ((food or nourish* or nutrition ${ }^{*}$ or sustenance or ration ${ }^{*}$ or meal ${ }^{*}$ ) NEAR/3 (assist ${ }^{*}$ or relie* or help* or

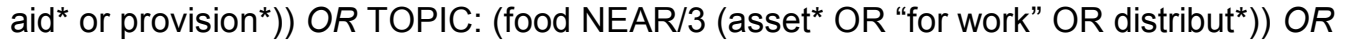
TOPIC: ((crisis OR emergenc* OR humanitarian) NEAR/3 (aid* OR relie* OR assist* OR interven* OR help)) OR TOPIC: (relief NEAR/3 (work* or program* ${ }^{*}$ or assist ${ }^{*}$ or co-op* or cooper* or initiativ $\left.{ }^{*}\right)$ )

\section{World Wide Political science abstracts}

\section{Results: 115}

(((food OR nourish* OR nutrition* OR sustenance OR ration* OR meal*) NEAR/3 (assist* OR relief* OR help* OR aid* OR provision*)) OR (food NEAR/3 (asset* OR "for work" OR distribute $^{*}$ ) OR (crisis OR emergenc* OR humanitarian OR international) NEAR/3 (aid* OR

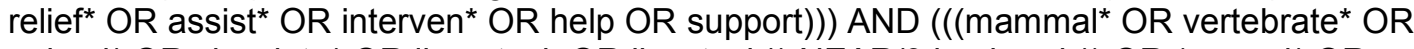

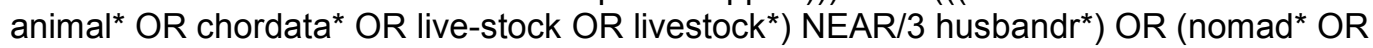
transhuman ${ }^{*}$ OR itinerant ${ }^{*}$ OR migrant* OR pastoral ${ }^{*}$ OR agr*$^{*}$-pastoral $\left.{ }^{\star}\right)$ ) 


\section{PAIS International}

\section{Results: 146}

(((food OR nourish* OR nutrition* OR sustenance OR ration* OR meal*) NEAR/3 (assist* OR relief* OR help* OR aid* OR provision*)) OR (food NEAR/3 (asset* OR "for work" OR distribute $^{*}$ ) OR (crisis OR emergenc* OR humanitarian OR international) NEAR/3 (aid* OR relief $^{*}$ OR assist ${ }^{*}$ OR interven* OR help OR support $\left.\left.\left.{ }^{\star}\right)\right)\right)$ AND $\left(\left(\left(\right.\right.\right.$ mammal $^{*}$ OR vertebrate ${ }^{*}$ OR animal $^{*}$ OR chordata* OR live-stock OR livestock*) NEAR/3 husbandr*) OR (nomad* OR transhuman* OR itinerant ${ }^{*}$ OR migrant ${ }^{*}$ OR pastoral ${ }^{*}$ OR agr $^{*}$-pastoral $\left.{ }^{*}\right)$ )

\section{Africa-Wide NiPAD}

\section{Results: 595}

(((food OR nourish* OR nutrition* OR sustenance OR ration* OR meal*) N3 (assist* OR relief* OR help* OR aid* OR provision*)) OR (food N3 (asset* OR "for work" OR distribut*)) OR ((crisis OR emergenc* OR humanitarian OR international) N3 (aid* OR relief* OR assist* OR interven* OR help OR support $)))$ AND (((mammal* OR vertebrate* OR animal* OR chordata* OR live-stock OR livestock*) N3 husbandr*) OR (nomad* OR transhuman* OR itinerant ${ }^{*}$ OR migrant* $^{*}$ OR pastoral ${ }^{*}$ OR agr -pastoral $\left.^{*}\right)$ )

\section{Google Scholar}

\section{Results: 412}

(pastoral ${ }^{*}$ OR nomad OR transient $^{*}$ OR migrant ${ }^{*}$ OR "animal husbandry" OR itinerant ${ }^{\star}$ ) AND (relief* OR aid* OR "food assist" ${ }^{*}$ OR "food asset" OR in-kind OR "food distribution" OR "meal distribution" OR humanitarian OR interven* OR help* OR support*)

\section{Cochrane}

\section{Results: $\mathbf{4 0}$}

Search Name: Oxfam HEP Search

Last saved: 03/06/2016 17:38:51.708

Description: Ran June 3, 2016

ID Search

\#1 MeSH descriptor: [Animal Husbandry] explode all trees

\#2 MeSH descriptor: [Agriculture] explode all trees

\#3 MeSH descriptor: [Animals] explode all trees

\#4 MeSH descriptor: [Transients and Migrants] explode all trees

\#5 (cattle or sheep or cow or mammal ${ }^{*}$ or livestock or live-stock or animal ${ }^{*}$ or llama* or yak $^{*}$ or goat* or camel ${ }^{*}$ ) near/3 husbandr*

\#6 (nomad $^{*}$ or transhuman ${ }^{*}$ or itineran ${ }^{*}$ or migrat ${ }^{*}$ ) near/3 (livelihood ${ }^{*}$ or farm* ${ }^{*}$ or societ ${ }^{*}$ or group* or lifestyle)

\#7 pastoral $^{*}$

\#8 agro near/3 pastoral

\#9 agr $^{*}$-pastoral ${ }^{*}$

\#10 MeSH descriptor: [Relief Work] explode all trees

\#11 MeSH descriptor: [Food Assistance] explode all trees

\#12 MeSH descriptor: [Disasters] explode all trees and with qualifier(s): [Prevention \& control - PC]

\#13 MeSH descriptor: [International Cooperation] explode all trees

\#14 (food or nourish ${ }^{*}$ or nutrition* or sustenance or ration* ${ }^{*}$ or meal ${ }^{*}$ ) near/3 (assist ${ }^{*}$ or relief* $^{*}$ or relie* or help* or aid* or provision*)

\#15 in-kind* near/3 (food* or nutrition* or meal* or nourish* or ration*)

\#16 in-kind near/3 (assist* or aid*)

\#17 food near/3 (distribut ${ }^{*}$ or work* or asset $^{*}$ )

\#18 humanitarian* near/3 (relie* or aid* or intervention* or assist* or help* or interven*)

\#19 humanitarian near/3 (mission* or coopera* or co-op*)

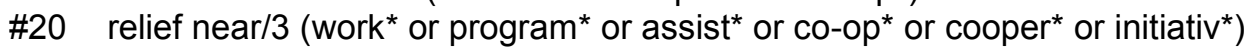


\#21 international near/3 (cooperat* or co-op* or assist* or relie* or aid* or help* or aid*)

\#22 \#1 or \#2 or \#3 or \#4 or \#5 or \#6 or \#7 or \#8 or \#9

\#23 \#10 or \#11 or \#12 or \#13 or \#14 or \#15 or \#16 or \#17 or \#18 or \#19 or \#20 or \#21

\#24 \#22 and \#23

\section{IDEAS}

\section{Results: 4,101}

(pastoral ${ }^{*} \mid$ nomad $^{*} \mid$ transient*$^{*} \mid$ migrant*$^{*} \mid$ transhuman*|"animal husbandr*"|agr*-pastoral) + (relie*|aid*|"food assis*"|in-kind|interven*|humanitarian*|asset*|food*|help|support*)

\section{International Bibliography of the Social Sciences}

\section{Results: 142}

(((food OR nourish* OR nutrition* OR sustenance OR ration* OR meal*) NEAR/3 (assist* OR relief* OR help* OR aid* OR provision*)) OR (food NEAR/3 (asset* OR "for work" OR

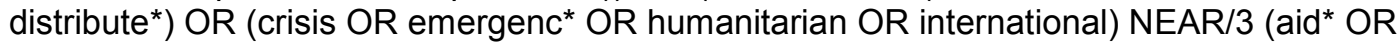

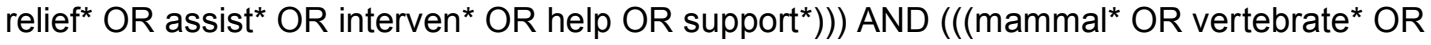
animal* OR chordata* OR live-stock OR livestock*) NEAR/3 husbandr*) OR (nomad* OR transhuman* OR itinerant* OR migrant* OR pastoral* OR agr*-pastoral* $\left.{ }^{*}\right)$

\section{ARTFL-FRANTEXT (French)}

\section{Results: 2,084}

Paste in the "Search in texts for" search bar: nomad. *|transient. *|transhuman*|itinerant. ${ }^{*}$ pastoral. *

\section{EMBASE}

\section{Results: 1,608}

\section{Database(s): Embase Classic+Embase 1947 to 2016 Week 23}

(((food or nourish* or nutrition* or sustenance or ration* or meal*) adj3 (assist* or relief* or relie* or help* or aid* or provision*)).tw,sh,fs,kw,ot,hw or relief work/ or food assistance/ or (in-kind* adj3 (food* or nutrition* or meal* or nourish* or ration*)).tw,sh,fs,kw,ot,hw. or (inkind adj3 (assist* or aid*)).tw,sh,fs,kw,ot,hw. or (humanitarian* adj3 (relie* or aid* or intervention* or assist* or help* or interven*)).tw,sh,fs,kw,ot,hw. or International Cooperation/ or (humanitarian adj3 (mission* or coopera* or co-op*)).tw,sh,fs,kw,ot,hw or (relief adj3 (work* or program* or assist* or co-op* or cooper* or initiativ*)).tw,sh,fs,kw,ot,hw. or (international adj3 (cooperat* or co-op* or assist* or relie* or aid* or help* or aid $\left.^{*}\right)$ ).tw,sh,fs,kw,ot,hw. or disaster/pc) AND (pastoral*.tw,sh,fs,kw,ot,hw or animals, domestic/ or livestock/ or agr*-pastoral ${ }^{\star}$.tw,sh,fs,kw,ot,hw. or (agr* adj3 pastoral $^{*}$ ).tw,sh,fs,kw,ot,hw. or exp animal husbandry/ or *agriculture/ or exp migrant/ or emigrant/ or immigrant/ or (nomad* or migrant* or transhuman* or itinerant* $) . t w, s h, f s, k w, o t, h w$. or ((nomad* or transhuman* or itineran* or migrat*) adj3 (livelihood* or farm* or societ * or group* or lifestyle)).tw,hw,fs,sh,kw,ot.) 


\section{Grey literature sources and searches}

* The following sources were all searched on 6 June 2016.

\section{Addis Ababa University}

Searched, nothing found. Keywords used: pastoralism, pastoral, humanitarian.

\section{Center for International Development, Harvard University}

Broken down by domains, under Environment and Natural Resources, 2009 (earliest)-2016 date range https://research.hks.harvard.edu/publications/Policy_Domain.aspx

\section{Feinstein International Center}

FHI 360

Keyword: pastoralism

Results:

https://www.fhi360.org/explore/content?search_api_views_fulltext=pastoralism\&op=Search

Institute for Development Studies at the University of Nairobi

Keywords: pastoralism AND humanitarian intervention

Results:

This organization pointed to two repositories for information, which were also searched:

\section{Institute of Development Studies, University of Nairobi}

Keywords: nomad* OR transient* OR itineran* OR transhuman* OR pastoralis* OR migrant* OR "animal husbandry"

Results:

http://opendocs.ids.ac.uk/opendocs/handle/123456789/28/discover?query=nomad ${ }^{*}+\mathrm{O}$ $\mathrm{R}+$ transient ${ }^{*}+\mathrm{OR}+$ itineran $^{*}+\mathrm{OR}+$ transhuman $^{*}+\mathrm{OR}+$ pastoralis ${ }^{*}+\mathrm{Or}+$ migrant $^{*}+\mathrm{OR}+\% 22$ animal+husbandry\%22\&submit=Go

\section{University of Nairobi digital repository}

Keywords:

nomad* OR transient* OR itineran* OR transhuman* OR pastoralis* OR migrant* OR "animal husbandry"

Results:

http://erepository.uonbi.ac.ke:8080/xmlui/discover?filtertype 3=title\&filter relational_o perator_3=contains\&filter_3=\&submit_apply_filter=Apply\&query $=$ nomad ${ }^{*}+O R+$ transie $\mathrm{nt}^{*}+\mathrm{OR}+{ }^{-}$itineran ${ }^{*}+\mathrm{OR}+$ transhuman $^{*}+\mathrm{OR}+$ pastoralis ${ }^{*}+\mathrm{Or}+$ migrant $^{*}+\mathrm{OR}+\% 22 \mathrm{animal}+\mathrm{h}$ usbandry $\% 22 \&$ scope $=\% 2 \mathrm{~F}$

\section{Institute for Global Health at University College London}

Use keyword: pastoralism. No stable URL available to share results.

\section{Institute of Development Studies at the University of Sussex}

Different pockets to search:

\section{Publication search:}

Keyword: Pastoralism

\section{Research on Livestock and Pastoralism:}

No keyword needed, area can be browsed.

\section{Advanced search (click on it):}

Keywords: pastoralis* OR husbandry 
International Institute for Environment and Development (IIED)

Keyword: Pastoralis*

Results:

http://pubs.iied.org/search.php?k=pastoralis $\& \mathrm{t}=\& \mathrm{a}=\& \mathrm{w}=\& \mathrm{~s}=\& \mathrm{c}=\& \mathrm{~g}=\& \mathrm{l}=\& \mathrm{tdB}=1 \& \mathrm{tdC}=1 \& \mathrm{td} \mathrm{A}$

$=1 \& \operatorname{td} J=1 \& \mathrm{tdF}=1 \& \operatorname{tg} \mathrm{I}=1 \& \operatorname{tg} \mathrm{P}=1 \& \operatorname{tg} \mathrm{E}=1 \& \mathrm{tmd}=1 \& \mathrm{tmf}=1 \& \mathrm{~d}=\mathrm{a} \& \mathrm{~b}=\mathrm{d} \& \mathrm{r}=\mathrm{a} \& \mathrm{z}=$ Search

International Livestock Research Institute (ILRI), Makerere University:

http://www.ilri.org/

Keywords: (pastoralism OR nomad OR transient OR migrant OR husbandry OR itinerant OR transhuman) AND (food OR aid OR relief OR support OR help OR in-kind OR assistance OR intervention)

Results:

https://books.google.com/books/p/international_livestock_research_institute?oe=UTF$8 \& \mathrm{q}=\% 28$ pastoralism+OR+nomad $+\mathrm{OR}+$ transient $+\mathrm{OR}+$ migrant+OR+husbandry+OR+itineran $\mathrm{t}+\mathrm{OR}+$ transhuman $\% 29+\mathrm{AND}+\% 28$ food+OR+aid+OR+relief+OR+support+OR+help+OR+inkind+OR+assistance+OR+intervention\%29\&btnG=Search+Books

Overseas Development Institute, Oxford Policy Management

Keywords: pastoral, pastoralism, husbandry, nomad.

Nothing was retrieved.

\section{Danish International Development Agency (DANIDA)}

Keywords: pastoralism OR nomad OR transient OR itinerant OR migrant OR transhuman

Results:

http://um.dk/search?q=pastoralism\%200R\%20nomad\%200R\%20transient\%200R\%20itiner ant $\% 200 R \% 20$ migrant\%200R\%20transhuman\&filter=0

\section{Deutsche Gesellschaft für Internationale Zusammenarbeit (GIZ)}

Keywords: pastoral* OR nomad* OR transient* OR migrant* OR transient* OR transhuman* OR husbandr*

Site doesn't support permanent search; go here: http://star-

www.giz.de/starweb/giz/pub/servlet.starweb?path=giz/pub/pub.web\&STAR_AppLanguage=1 and copy and paste the keywords above.

\section{European Union Humanitarian Aid and Civil Protection (ECHO)}

Keyword: pastoralism

Other sites identified:

\section{European Commission}

Results:

http://ec.europa.eu/geninfo/query/index.do?queryText=pastoralism+\&summary=summ ary\&more_options_source $=$ global $\&$ more_options_date $=* \&$ more_options_date_from $=\&$

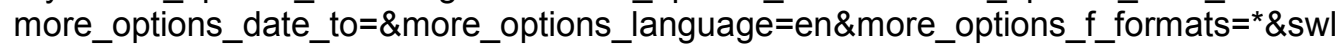
ang=en

\section{EU Aid Explorer:}

https://euaidexplorer.ec.europa.eu/SearchPageAction.do

Use keyword: pastoralist

No ability to save a search string, copy and paste keyword above. Go to both Development and Humanitarian Projects.

\section{International Cooperation and Development}

Keyword: pastoralism

Results: http://ec.europa.eu/europeaid/search/library/pastoralism_en 


\section{Swedish International Development Agency}

Keywords: pastoralist OR pastoralism OR nomad OR transient OR migrant OR itinerant OR transhuman

Results:

http://www.sida.se/English/search/?site=www.sida.se\%2FEnglish\%2F\&q=pastoralist $+O R+p$ astoralism+OR+nomad+OR+transient+OR+migrant+OR+itinerant+OR+transhuman

\section{United Kingdom Department for International Development}

Keywords: pastoralism

Results:

https://www.gov.uk/search?q=pastoralism

\section{United States Office of Foreign Disaster Assistance}

Keywords: pastoralist OR pastoralism OR nomad OR transient OR migrant OR itinerant OR transhuman

Results:

https://www.usaid.gov/gsearch/\%2BOR\%2Bpastoralism\%2BOR\%2Bnomad\%2BOR\%2Btran sient\%2BOR\%2Bmigrant\%2BOR\%2Bitinerant\%2BOR\%2Btranshuman

\section{African Development Bank}

Keywords: pastoralist OR pastoralism OR nomad OR transient OR migrant OR itinerant OR transhuman

Results:

http://www.afdb.org/en/search/?query=pastoralist+OR+pastoralism+OR+nomad+OR+transie $\mathrm{nt}+\mathrm{OR}+$ migrant+OR+itinerant+OR+transhuman

\section{Asian Development Bank}

Keywords: pastoralist

Results:

http://www.adb.org/search?keywords=pastoralist

\section{International Committee of the Red Cross}

Keywords: (pastoralist OR pastoralism OR nomad OR transient OR migrant OR itinerant OR transhuman) AND (aid OR relief OR support OR assistance OR in-kind OR food OR help OR humanitarian OR intervention)

Results:

https://www.icrc.org/en/resource-

centre/result?context=hf\%253D7\%2526s\%253D\%2526logic\%253Dinternet-

eng $\% 2526 q \% 253 \mathrm{D} \% 252528$ pastoralist $\% 252 \mathrm{BOR} \% 252 \mathrm{~B}$ pastoralism $\% 252 \mathrm{BOR} \% 252 \mathrm{Bnoma}$ d\%252BOR\%252Btransient $\% 252 B O R \% 252 B$ migrant $\% 252 B O R \% 252 B$ itinerant $\% 252 B O R \%$ 252Btranshuman\%252529\%252BAND\%252B\%252528aid\%252BOR\%252Brelief\%252BOR \%252Bsupport\%252BOR\%252Bassistance\%252BOR\%252Bin-

kind\%252BOR\%252Bfood\%252BOR\%252Bhelp\%252BOR\%252Bhumanitarian\%252BOR\% 252Bintervention $\% 252529 \% 2526 s a \% 253 D 0 \& s=\& s a=1 \& b=0$

International Organization for Migration, Office for the Coordination of Humanitarian Affairs

Keywords: pastoralist

Results:

http://www.iom.int/search/pastoralist

Office of the United Nations High Commissioner for Refugees, United Nations

Keywords: pastorali*

Results:

http://www.unhcr.org/search?query=pastorali* 


\section{UNICEF}

Keywords: pastoralist

Results:

http://www.unicef.org/search/search.php?querystring_en=pastoralist+\&hits=\&type=\&navigati on $=\& G o \cdot x=0 \& G o \cdot y=0$

* The following sources were all searched on 7 June 2016.

\section{World Bank}

Keywords: (pastoralist OR pastoralism OR nomad OR transient OR migrant OR itinerant OR transhuman) AND (aid OR relief OR support OR assistance OR in-kind OR "food assistance" OR help OR humanitarian OR intervention)

Results (limited to English):

http://search. worldbank.org/all?qterm $=\% 28$ pastoralist+OR+pastoralism+OR+nomad+OR+tra nsient+OR+migrant+OR+itinerant+OR+transhuman\%29+AND+\%28aid+OR+relief+OR+sup port+OR+assistance+OR+in-

kind+OR+\%22food+assistance $\% 22+O R+h e l p+O R+h u m a n i t a r i a n+O R+i n t e r v e n t i o n \% 29+\&$ titl $\mathrm{e}=$ \&filetype $=$ \&_Top/language $=$ English

Results (limited to French):

http://search.worldbank.org/all?qterm $=\% 28$ pastoralist+OR+pastoralism+OR+nomad+OR+tra nsient+OR+migrant+OR+itinerant+OR+transhuman $\% 29+A N D+\% 28$ aid+OR+relief+OR+sup port+OR+assistance+OR+in-

kind+OR+\%22food+assistance $\% 22+O R+h e l p+O R+$ humanitarian+OR+intervention $\% 29+\&$ titl e=\&filetype $=$ \&_Top/language $=$ French

\section{World Health Organization}

Keywords: pastoralism AND (aid OR relief OR support OR assistance OR in-kind OR "food assistance" OR help OR humanitarian OR intervention)

Pastoralist AND (aid OR relief OR support OR assistance OR in-kind OR "food assistance" OR help OR humanitarian OR intervention)

Transhumance AND (aid OR relief OR support OR assistance OR in-kind OR "food assistance" OR help OR humanitarian OR intervention)

Advanced Google search, look into site: who.int

In find any of these words typed keywords above. Limit by year to 1967-2016

\section{Action Against Hunger}

Keywords: pastoralist OR pastoralism OR nomad OR transient OR itinerant OR transhumance

Results:

http://www.actionagainsthunger.org/search/node/pastoralist\%200R\%20pastoralism\%200R \%20nomad\%200R\%20transient\%200R\%20itinerant\%200R\%20transhumance

\section{International Rescue Committee}

Keywords: pastoralist OR pastoralism OR nomad OR transient OR itinerant OR transhumance

Results:

http://www.rescue.org/search/node/pastoralist\%200R\%20pastoralism\%200R\%20nomad\%2 0OR\%20transient $\% 200 R \% 20$ itinerant\%200R\%20transhumance

\section{Médecins Sans Frontières/Doctors Without Borders}

Keywords: pastoralist OR pastoralism OR nomad OR transient OR itinerant OR transhumance

Results:

http://www.msf.org/en/search?keyword=pastoralist $\% 200 R \% 20$ pastoralism\%200R\%20noma d\%20OR\%20transient\%200R\%20itinerant\%200R\%20transhumance 


\section{Oxfam Canada}

Keywords: pastoralist OR pastoralism OR nomad OR transient OR itinerant OR transhumance

Results:

http://www.oxfam.ca/search/node/pastoralist $\% 200 R \% 20$ pastoralism\%200R\%20nomad\%20 OR\%20transient $\% 200 R \% 20$ itinerant $\% 200 R \% 20$ transhumance

\section{Save the Children}

Keywords: pastoralist OR pastoralism OR nomad OR transient OR itinerant OR transhumance

Results:

https://www.savethechildren.net/search/node/pastoralist $\% 200 R \% 20$ pastoralism\%20OR\%20 nomad\%200R\%20transient\%200R\%20itinerant\%200R\%20transhumance

\section{Vétérinaires Sans Frontières}

Keywords: pastoralist OR pastoralism OR nomad OR transient OR itinerant OR transhumance

Results:

Advanced Google search, look into site: vsf-international.org

\section{The Bill \& Melinda Gates Foundation}

Keywords: pastoralist OR pastoralism OR nomad OR transient OR itinerant OR transhumance

Results:

http://www.gatesfoundation.org/search\#q/k=pastoralist\%200R\%20pastoralism\%200R\%20n omad\%200R\%20transient $\% 200 R \% 20$ itinerant\%200R\%20transhumance

\section{The Clinton Foundation}

Keywords: pastoralist OR pastoralism OR nomad OR transient OR itinerant OR transhumance

\section{Results:}

https://www.clintonfoundation.org/search/node/pastoralist\%200R\%20pastoralism $\% 200 R \% 2$ Onomad\%200R\%20transient\%200R\%20itinerant\%200R\%20transhumance

\section{The Gatsby Charitable Foundation}

Keywords: pastoralist OR pastoralism OR nomad OR transient OR itinerant OR transhumance

Results (no results):

http://www.gatsby.org.uk/search-

results?term=pastoralist+OR+pastoralism+OR+nomad+OR+transient+OR+itinerant+OR+tra nshumance+\&sort_by=relevant

\section{The Rockefeller Foundation}

Keywords: pastoralist OR pastoralism OR nomad OR transient OR itinerant OR transhumance

Results:

Advanced Google search, look into site: rockefellerfoundation.org 


\section{Open Grey}

Keywords: (pastoralist OR pastoralism OR nomad* OR transient* OR migrant ${ }^{*}$ OR itinerant ${ }^{*}$ OR transhuman*) AND (aid OR relie* OR support OR assist* OR in-kind OR "food assistance" OR help OR humanitarian OR interven*)

Results:

http://www.opengrey.eu/search/request?q=\%28pastoralist+OR+pastoralism+OR+nomad $+\mathrm{O}$ $\mathrm{R}+$ transient ${ }^{*}+\mathrm{OR}+$ migrant $^{*}+\mathrm{OR}+$ itinerant $^{*}+\mathrm{OR}+$ transhuman $^{*} \% 29+\mathrm{AND}+\% 28 \mathrm{aid}+\mathrm{OR}+$ relie $^{*}+$ $\mathrm{OR}+$ support+OR+assist ${ }^{*}+\mathrm{OR}+\mathrm{in}-$

kind+OR+\%22food+assistance $\% 22+O R+h e l p+O R+h u m a n i t a r i a n+O R+i n t e r v e n * \% 29$

\section{GreyLit}

Keywords: pastoralist OR pastoralism OR nomad OR transient OR itinerant OR transhumance

Results (no results):

http://www.greylit.org/library/search\#wt=json\&facet=true\&q=pastoralist $\% 200 R \% 20$ pastoralis $\mathrm{m} \% 200 \mathrm{R} \% 20$ nomad $\% 20$ OR\%20transient $\% 20$ OR\%20itinerant $\% 20$ OR $\% 20$ transhumance $\%$ $20 \& q t=d i s m a x \& f l=i d \& q f=f u l l$ text\&facet.field=publisher\&facet.field=full_subjects\&q.op=AND\& start $=0$ 


\section{APPENDIX 2: INCLUDED PUBLICATIONS AND REPORTED INTERVENTIONS AND IMPACTS}

\begin{tabular}{|c|c|c|c|}
\hline Publication & $\begin{array}{l}\text { Type of } \\
\text { Intervention }\end{array}$ & $\begin{array}{l}\text { Reported } \\
\text { Impact(s) }\end{array}$ & Description of Impact(s) \\
\hline \multicolumn{4}{|c|}{ HORN OF AFRICA } \\
\hline Taylor (1983) & $\begin{array}{l}\text { Unconditional } \\
\text { food aid }\end{array}$ & Health & $\begin{array}{l}\text { Children enrolled in food programmes gained weight over the course of access to } \\
\text { food relief. }\end{array}$ \\
\hline \multirow[t]{5}{*}{ Snow (1984) } & \multirow[t]{5}{*}{$\begin{array}{l}\text { Unconditional } \\
\text { food aid and } \\
\text { food-for-work }\end{array}$} & $\begin{array}{l}\text { Use of food } \\
\text { assistance }\end{array}$ & $\begin{array}{l}\text { Once food aid was implemented, there was an 'increase in alcoholism due to } \\
\text { distillation of corn, intended for relief, by people with adequate food supplies who } \\
\text { set up stills'. }\end{array}$ \\
\hline & & $\begin{array}{l}\text { Livelihood } \\
\text { strategies }\end{array}$ & $\begin{array}{l}\text { Established food-for-work projects leading to a life away from pastoralism towards } \\
\text { agriculture. A possible shift to a cash crop economy was also observed. }\end{array}$ \\
\hline & & Gender roles & $\begin{array}{l}\text { There was a growing tendency for young Turkana women to seek alternatives to } \\
\text { nomadic lifestyles. }\end{array}$ \\
\hline & & $\begin{array}{l}\text { Social } \\
\text { relations }\end{array}$ & $\begin{array}{l}\text { Food aid may have led to the creation of new power structures and power brokers } \\
\text { who challenge the authority of and respect given to elders. Furthermore, greater } \\
\text { concentration of people was observed in camps. }\end{array}$ \\
\hline & & Government & $\begin{array}{l}\text { Greater and increasing power of the Kenyan state and its ability to control the } \\
\text { Turkana was observed through the provision of food aid. }\end{array}$ \\
\hline $\begin{array}{l}\text { Adams and } \\
\text { Hawksley (1989) }\end{array}$ & $\begin{array}{l}\text { Unconditional } \\
\text { food aid }\end{array}$ & Security & $\begin{array}{l}\text { During the crisis in Darfur, food aid by non-governmental intervention was widely } \\
\text { lauded to have 'saved a great many lives during the emergency'. }\end{array}$ \\
\hline Ngunjiri (1989) & $\begin{array}{l}\text { Unconditional } \\
\text { food aid }\end{array}$ & $\begin{array}{l}\text { Mobility } \\
\text { patterns }\end{array}$ & $\begin{array}{l}\text { The provision of food aid contributed to internal distribution of both assets and } \\
\text { responsibilities: 'Stock owners tended to divide their herds in two in response to the } \\
\text { drought. Women, children, and older members of the household were often left with } \\
\text { the milk herd near centers where relief was likely to be provided. The men often } \\
\text { moved the remainder of the herd in search of better grazing in areas distant from } \\
\text { the center. Though this meant that the project tended to reach the most vulnerable } \\
\text { members of the household, it also meant that much of the stock put forward to } \\
\text { slaughter was female stock, which would have better have been retained for } \\
\text { rebuilding the herd after the drought.' }\end{array}$ \\
\hline Asmarom (1989) & $\begin{array}{l}\text { Unconditional } \\
\text { food aid }\end{array}$ & $\begin{array}{l}\text { Social } \\
\text { relations }\end{array}$ & $\begin{array}{l}\text { Demoralization of the community receiving food assistance was observed: 'It is the } \\
\text { closest thing to an Ik type of non-community that I ever observed in the Boran } \\
\text { country.' }\end{array}$ \\
\hline \multirow[t]{2}{*}{ McCabe (1990) } & \multirow[t]{2}{*}{$\begin{array}{l}\text { Unconditional } \\
\text { food aid }\end{array}$} & $\begin{array}{l}\text { Livelihood } \\
\text { strategies }\end{array}$ & $\begin{array}{l}\text { Compared with the nomadic Ngisonyoka of Southern Turkana, those in the } \\
\text { Ngilukumong, Ghiyapakuno, Ngikamatak and Ngibocheros sections of the northern } \\
\text { Turkana witnessed a breakdown of indigenous drought coping strategies. }\end{array}$ \\
\hline & & $\begin{array}{l}\text { Mobility } \\
\text { patterns }\end{array}$ & $\begin{array}{l}\text { The attraction of free food influenced traditional patterns of movement for many } \\
\text { individual herd-owners. If members of the family were receiving food aid, there was } \\
\text { a strong incentive for the herd-owner to try to remain near the relief centre. Once } \\
\text { new rules requiring whole families to apply for food aid were instituted, this became } \\
\text { a necessity. Since the environment close to the settlements was rapidly becoming } \\
\text { denuded, livestock which in many instances were already stressed were forced to } \\
\text { forage on sparser and less nutritious plants than they would have away from the } \\
\text { settlements. This practice inevitably led to livestock losses through starvation or } \\
\text { disease. Thus, the famine relief centres were, to some extent, creating their own } \\
\text { clients. }\end{array}$ \\
\hline Farzin (1991) & $\begin{array}{l}\text { Unconditional } \\
\text { food aid }\end{array}$ & $\begin{array}{l}\text { Access to } \\
\text { food }\end{array}$ & $\begin{array}{l}\text { The provision of food aid led to dependence upon its existence while having a } \\
\text { disincentive effect on the domestic food supply. }\end{array}$ \\
\hline Cutler (1991) & Not reported & $\begin{array}{l}\text { Income } \\
\text { dynamics }\end{array}$ & $\begin{array}{l}\text { Undermining the domestic food economy: grain prices dropped; labourers failed to } \\
\text { migrate where needed to assist with the harvest; and crops were left unharvested } \\
\text { because the market for them became too weak. }\end{array}$ \\
\hline \multirow[t]{2}{*}{ Kilby (1993) } & \multirow[t]{2}{*}{$\begin{array}{l}\text { Unconditional } \\
\text { food aid }\end{array}$} & $\begin{array}{l}\text { Mobility } \\
\text { patterns }\end{array}$ & $\begin{array}{l}\text { As a result of food aid, those from the Red Sea Hills had increased rates of } \\
\text { sedentarization. }\end{array}$ \\
\hline & & $\begin{array}{l}\text { Income } \\
\text { dynamics }\end{array}$ & $\begin{array}{l}\text { The food assistance programmes in Sudan were compared with the Oxfam } \\
\text { restocking project in Kenya (Moris, 1988): 'The results suggest that it is still far more } \\
\text { economic to restock than to provide food aid for four years.' Furthermore, food aid } \\
\text { had little positive effect on human mortality levels. }\end{array}$ \\
\hline
\end{tabular}




\begin{tabular}{|c|c|c|c|}
\hline Publication & $\begin{array}{l}\text { Type of } \\
\text { Intervention }\end{array}$ & $\begin{array}{l}\text { Reported } \\
\text { Impact(s) }\end{array}$ & Description of Impact(s) \\
\hline \multirow[t]{3}{*}{ Bush (1995) } & \multirow[t]{3}{*}{$\begin{array}{l}\text { Unconditional } \\
\text { food aid }\end{array}$} & $\begin{array}{l}\text { Livelihood } \\
\text { patterns }\end{array}$ & $\begin{array}{l}\text { Food aid led to a strengthening of herd growth and filled income gaps among } \\
\text { recipients. }\end{array}$ \\
\hline & & Health & There was a decline in rates of childhood malnutrition. \\
\hline & & $\begin{array}{l}\text { Social } \\
\text { relations }\end{array}$ & Food aid led to a strengthening of social networks. \\
\hline \multirow{2}{*}{$\begin{array}{l}\text { Buchanan-Smith } \\
\text { and Barton } \\
(1999)\end{array}$} & \multirow[t]{2}{*}{$\begin{array}{l}\text { Unconditional } \\
\text { food aid }\end{array}$} & $\begin{array}{l}\text { Livelihood } \\
\text { strategies }\end{array}$ & $\begin{array}{l}\text { The provision of food aid resulted in a reduction in livestock sales while reducing } \\
\text { overall individual-level and household debt. }\end{array}$ \\
\hline & & Health & Similarly, rates of malnutrition decreased during the provision of food aid. \\
\hline No author (2001) & Not reported & Health & $\begin{array}{l}\text { Health was substantially impacted through food aid: 'Even though food aid and } \\
\text { feeding centers are a priority during famine, attracting a large concentration of } \\
\text { susceptible persons to feeding centers may increase transmission of infectious } \\
\text { diseases such as measles and diarrhea.' }\end{array}$ \\
\hline \multirow[t]{3}{*}{ Pantuliano (2002) } & \multirow[t]{3}{*}{ Food-for-work } & $\begin{array}{l}\text { Livelihood } \\
\text { strategy }\end{array}$ & $\begin{array}{l}\text { Changes in livelihood strategy patterns were observed, in particular a weakening of } \\
\text { the Beja livelihood system. }\end{array}$ \\
\hline & & $\begin{array}{l}\text { Mobility } \\
\text { patterns }\end{array}$ & Food aid contributed to increased sedentarization and urban drift among recipients. \\
\hline & & $\begin{array}{l}\text { Social } \\
\text { relations }\end{array}$ & $\begin{array}{l}\text { Aid distribution created a new class of 'food shaikhs', which brought about a } \\
\text { modification of the existing social structure and the traditional inter-diwab dynamics } \\
\text { founded on exchange of resources and reciprocity. }\end{array}$ \\
\hline $\begin{array}{l}\text { Overseas } \\
\text { Development } \\
\text { Institute (2006) }\end{array}$ & Not reported & $\begin{array}{l}\text { Livelihood } \\
\text { strategies }\end{array}$ & $\begin{array}{l}\text { Although limited details were provided on the impact of food aid, the authors noted: } \\
\text { 'The humanitarian response to the crisis in the Greater Horn of Africa has done very } \\
\text { little, to date, to protect livelihoods.' }\end{array}$ \\
\hline \multirow[t]{2}{*}{ Pantuliano (2007) } & \multirow[t]{2}{*}{$\begin{array}{l}\text { Unconditional } \\
\text { food aid }\end{array}$} & $\begin{array}{l}\text { Mobility } \\
\text { patterns }\end{array}$ & $\begin{array}{l}\text { Sedentarization increased as a result of food aid, not only leading to a } \\
\text { strengthening of internal political divisions but also establishing power brokers. }\end{array}$ \\
\hline & & Environment & Potentially negative environmental impacts, but no further details reported. \\
\hline Adow (2008) & Food aid & $\begin{array}{l}\text { Livelihood } \\
\text { strategies }\end{array}$ & $\begin{array}{l}\text { Movement patterns changed in response to food aid: 'Many move near urban } \\
\text { centres to seek emergency food aid.' }\end{array}$ \\
\hline \multirow[t]{2}{*}{ Nangulu (2009) } & \multirow[t]{2}{*}{ Not reported } & $\begin{array}{l}\text { Livelihood } \\
\text { strategies }\end{array}$ & $\begin{array}{l}\text { Patterns in livelihood strategies have been substantially undermined by the receipt } \\
\text { of food aid. }\end{array}$ \\
\hline & & Dependency & Food aid may lead to dependence and increase poverty among recipients. \\
\hline Stockton (2012) & Not reported & $\begin{array}{l}\text { Mobility } \\
\text { patterns }\end{array}$ & $\begin{array}{l}\text { Through the receipt of food aid, populations are reported to be increasingly } \\
\text { sedentary. Although sedentarization is claimed to be the consequence of food aid, it } \\
\text { may be more a result of the development of water resources, which takes place } \\
\text { alongside the provision of food aid. }\end{array}$ \\
\hline Lekapana (2013) & Not reported & Dependency & $\begin{array}{l}\text { 'Successive drought episodes have forced pastoral communities to rely on } \\
\text { emergency food aid, which have reinforced the cycle of dependency.' }\end{array}$ \\
\hline \multirow[t]{3}{*}{$\begin{array}{l}\text { Bersaglio et al. } \\
(2015)\end{array}$} & \multirow[t]{3}{*}{$\begin{array}{l}\text { Unconditional } \\
\text { food aid }\end{array}$} & $\begin{array}{l}\text { Livelihood } \\
\text { strategies }\end{array}$ & $\begin{array}{l}\text { Livelihood patterns have been modified in response to food aid, including the } \\
\text { creation of new spaces for community collaboration. However, this has also } \\
\text { contributed to a movement away from pastoralism. }\end{array}$ \\
\hline & & Well-being & $\begin{array}{l}\text { A reduction in anxiety, improvement of living standards and enhanced spirituality } \\
\text { were observed with food aid receipt. }\end{array}$ \\
\hline & & $\begin{array}{l}\text { Access to } \\
\text { food }\end{array}$ & $\begin{array}{l}\text { Although food aid was offered to all, unequal distribution of available goods was } \\
\text { reported. }\end{array}$ \\
\hline \multicolumn{4}{|l|}{ AFRICA, OTHER } \\
\hline News24 (2005) & $\begin{array}{l}\text { Unconditional } \\
\text { food aid }\end{array}$ & $\begin{array}{l}\text { Livelihood } \\
\text { strategies }\end{array}$ & $\begin{array}{l}\text { Changes in income dynamics were reported: 'Many international and non- } \\
\text { governmental agencies, including Catholic Relief Services and the European Union, } \\
\text { have expressed concern that free food distributions after the harvests will drive millet } \\
\text { prices below market value and damage the chances of recovery for indebted farmers.' }\end{array}$ \\
\hline \multirow{2}{*}{$\begin{array}{l}\text { Cicalese et al. } \\
(2009)\end{array}$} & \multirow[t]{2}{*}{ Not reported } & Security & Food aid was provided during the Moroccan invasion of the Western Sahara. \\
\hline & & $\begin{array}{l}\text { Access to } \\
\text { food }\end{array}$ & $\begin{array}{l}\text { Food aid provided was reported to be insufficient and unbalanced, leading to } \\
\text { widespread malnutrition among the recipient population. }\end{array}$ \\
\hline \multicolumn{4}{|l|}{ ASIA } \\
\hline No author (2002) & Not reported & $\begin{array}{l}\text { Use of food } \\
\text { assistance }\end{array}$ & $\begin{array}{l}\text { Compared to those herders in districts only slightly or not affected: 'Relief efforts to } \\
\text { distribute food to affected areas might have lessened the nutritional impact of } \\
\text { livestock losses among herders and their families.' }\end{array}$ \\
\hline $\begin{array}{l}\text { Fernandez- } \\
\text { Gimenez et al. } \\
(2012)\end{array}$ & $\begin{array}{l}\text { Unconditional } \\
\text { food aid }\end{array}$ & Dependency & $\begin{array}{l}\text { Food aid may have created dependence among recipients: 'Relief aid that helps } \\
\text { prevent loss of life, suffering, and impoverishment in the short-term may contribute } \\
\text { to long-term dependence syndromes, social disparities, and lack of initiatives on the } \\
\text { part of both herders and local government.' }\end{array}$ \\
\hline
\end{tabular}




\section{REFERENCES}

\section{INCLUDED PUBLICATIONS}

Adams, M.E. and Hawksley, E. (1989). Merging Relief and Development: The Case of Darfur. Development Policy Review 7: 143-69.

Adow, M. (2008). Pastoralists in Kenya. Forced Migration Review, no. 31: 34.

Asmarom Legesse (1989). Adaptation, drought, and development: Boran and Gabra pastoralists of northern Kenya. In: Huss Ashmore, R. and Katz, S.H. (eds), African Food Systems in Crisis. Part one: Microperspectives. Gordon and Breach, New York, USA, pp.261-280.

Bersaglio, B., Devlin, J. and Yap, N. (2015). Contextualising Emergency Responses to Famine among Turkana Pastoralists in Kenya. Development in Practice 25 (5). Taylor \& Francis: 688-702.

Buchanan-Smith, M. and Barton, D. (1999). Evaluation of the Wajir Relief Programme: 1996-1998. Oxford: Oxfam.

Bush, J. (1995). The Role of Food Aid in Drought and Recovery: Oxfam's North Turkana (Kenya) Drought Relief Programme, 1992-94. Disasters 19 (3).

Cicalese, M.P., Ranucci, G. et al. (2009). Nutritional Impact Analysis of the Food Aids Distributed in the Saharawi Refugee Camps: Possible Implication with Celiac Disease. Digestive and Liver Disease 41S. Editrice Gastroenterologica Italiana S.r.I.: S221-22. doi:10.1016/S1590-8658(09)60504-1

Cutler, P. (1991). The Political Economy of Famine in Ethiopia and Sudan. Ambio 20 (5): 176-78.

Farzin, Y.H. (1991). Food Aid: Positive or Negative Economic Effects in Somalia? The Journal of Developing Areas 25 (2): 261-82.

Fernandez-Gimenez, M.E., Batkhishig, B. and Batbuyan, B. (2012) Cross-Boundary and Cross-Level Dynamics Increase Vulnerability to Severe Winter Disasters (Dzud) in Mongolia. Global Environmental Change 22 (4): 836-51. doi:10.1016/j.gloenvcha.2012.07.001

Kilby, P. (1993). Emergency Relief Programmes for Pastoral Communities. Development in Practice 3 (2): 92-102. doi:10.1080/096145249100077101

Lekapana, P.L. (2013). Socioeconomic Impacts of Drought on Pastoralists, Their Coping Strategies, and Government Interventions in Marsabit County, Kenya. University of Nairobi.

McCabe, T. (1990). Success and Failure: The Breakdown of Traditional Drought Coping Institutions Among the Pastoral Turkana of Kenya. Journal of Asian and African Studies XXV (3-4): 146-60.

Nangulu, A.K. (2009). Food Security and Coping Mechanisms in Marginal Areas. The Case of West Pokot, Kenya, 1920-1995. Leiden: African Studies Centre.

News24 (2005). UN: Niger Food Aid to Continue. News24, 19 May.

Ngunjiri, E. (1989) Relief and recovery for pastoralists: Oxfam's experience. In Downing, T.E., Gitu, K.W. and Kamau, C.M. (eds.) Coping with Drought in Kenya: National and Local Strategies, pp. 344-351. Lynne Rienner, Boulder. 
No author (2001). Mortality During a Famine - Gode District, Ethiopia, July 2000. Morbidity and Mortality Weekly Report 50 (15).

No author (2002). Nutritional Assessment of Children after Severe Winter Weather Mongolia, June 2001. Morbidity and Mortality Weekly Report 51 (1).

Overseas Development Institute (2006). Saving Lives through Livelihoods: Critical Gaps in the Response to the Drought in the Greater Horn of Africa. London: Humanitarian Policy Group, ODI. Retrieved 28 April 2016, from https://www.odi.org/publications/1381-livelihoodsresponse-drought-greater-horn-africa

Pantuliano, S. (2007). From Food Aid to Livelihoods Support: Rethinking the Role of WFP in Eastern Sudan. Disasters 31 (S1): 77-90.

Pantuliano, S. (2002). Sustaining Livelihoods across the Rural-Urban Divide: Changes and Challenges Facing the Beja Pastoralists of North Eastern Sudan. London: International Institute for Environment and Development (IIED).

Snow, R. (1984). Famine relief: some unanswered questions from Africa. In: Tietze, W. (ed.), Famine as a Geographical Phenomenon. D. Reidel Publishing, Holland.

Stockton, G. (2012). Sugar for the Tea: Assistance and the State of Pastoralism in the Horn of Africa. Pastoralism: Research, Policy and Practice 2 (6): 1-10.

Taylor, W.R. (1983). An Evaluation of Supplementary Feeding in Somali Refugee Camps. International Journal of Epidemiology 12 (4): 433-36. doi:10.1093/ije/12.4.433

Abbink, J. (1993). Famine, Gold and Guns: The Suri of Southwestern Ethiopia, 1985-91. Disasters 17 (3): 218-25.

Abbink, J., Askew, K. et al. (2014). Lands of the Future: Transforming Pastoral Lands and Livelihoods in Eastern Africa. Halle/Saale: Max Planck Institute for Social Anthropology Working Paper 154.

Abebe, D., Cullis, A. et al. (2008). Impact of a Commercial Destocking Relief Intervention in Moyale District, Southern Ethiopia. Disasters 32 (2): 167-89.

Arksey, H. and O'Malley, L. (2005) Scoping studies: towards a methodological framework. International Journal of Social Research Methodology 8: 19-32

Action Against Hunger (2011). Final Independent Evaluation of the Provision of Food Aid and Livelihood Disaster Prevention to the Most Dzud-Affected Herders in Mongolia. New York: Action Against Hunger. Retrieved 27 April 2016, from http://www.alnap.org/resource/21074

Aker, J. (2008). How Can We Avoid Another Food Crisis in Niger? Washington, D.C.: Center for Global Development. Retrieved 27 April 2016, from

http://www.cgdev.org/publication/how-can-we-avoid-another-food-crisis-niger-essay

Bassi, M. (2010). The Politics of Space in Borana Oromo, Ethiopia: Demographics,

Elections, Identity and Customary Institutions. Journal of Eastern African Studies, 4(2), $221-$ 46.

Bellos, A., Mulholland, K. et al. (2010). The Burden of Acute Respiratory Infections in CrisisAffected Populations: A Systematic Review. Conflict and Health, 4(3). Retrieved 27 April 2016, from http://conflictandhealth.biomedcentral.com/articles/10.1186/1752-1505-4-3

Bishop, C. and Hilhorst, D. (2010). From Food Aid to Food Security: The Case of the Safety Net Policy in Ethiopia. Journal of Modern African Studies, 48(02):181-202. 
Blackwell, P.J. (2010). East Africa's Pastoralist Emergency: Is Climate Change the Straw That Breaks the Camel's Back? Third World Quarterly 31 (8): 1321-38.

Boulton, J. (2012). Turkana through the Lens of Complexity: Final Report for Oxfam GB Kenya. Nairobi: Oxfam.

Butt, B., Shortridge, A. and WinklerPrins, A.M.G.A. (2009). Pastoral Herd Management, Drought Coping Strategies, and Cattle Mobility in Southern Kenya. Annals of the Association of American Geographers, 99(2):309-34.

Central Bank of Somalia. (n.d.) Economy and Finance. Retrieved 27 January 2016, from http://www.somalbanca.org/economy-and-finance.html

Chi, P., Urdal, H. et al. (2015). Improving Maternal, Newborn and Women's Reproductive Health in Crisis Settings. London: Cochrane Collaboration. Retrieved 28 April 2016, from http://www.cochrane.org/CD011829/EPOC_improving-maternal-newborn-and-womensreproductive-health-crisis-settings

Clay, E.J. (2010). A Future Food Aid or Food Assistance Convention? London: Overseas Development Institute (ODI). Retrieved 28 April 2016, from https://www.odi.org/publications/4941-food-food-aid

Crumlish, N. and O'Rourke, K. (2010). A Systematic Review of Treatments for PostTraumatic Stress Disorder Among Refugees and Asylum-Seekers. The Journal of Nervous and Mental Disease, 198(4):237-251. Retrieved 28 April 2016, from http://journals.Iww.com/jonmd/Abstract/2010/04000/A_Systematic_Review_of_Treatments_f or.1.aspx

Czuba, K. and O'Neill, T.J. (2016). The impact of food assistance on pastoralist livelihoods in humanitarian crises: an evidence synthesis protocol. Oxford: Oxfam GB.

DiCenso, A., Martin-Misener, R. et al. (2010). Advanced Practice Nursing in Canada: Overview of a Decision Support Synthesis. Nursing Leadership, 23:15-34. Retrieved 28 April 2016, from http://www.longwoods.com/content/22267

Doocy, S. and Tappis, H. (2015). The Effectiveness and Efficiency of Cash-based Approaches in Emergencies: A Systematic Review. Oslo: The Campbell Collaboration.

Food and Agriculture Organization of the United Nations (FAO). (n.d.). Pastoral Systems Worldwide. Rome: FAO. Retrieved 28 April 2016, from http://www.fao.org/docrep/005/y2647e/y2647e02.htm

Fratkin, E. (1992). Drought and Development in Marsabit District, Kenya. Disasters 16 (2): 119-30.

Fratkin, E. (2001). East African Pastoralism in Transition: Maasai, Boran, and Rendille Cases. African Studies Review, 44(3):1-25. Retrieved 28 April 2016, from http://journals.cambridge.org/action/displayAbstract?aid=9124324

Fratkin, E., Roth, E.A. and Nathan, M.A. (2004). Pastoral Sedentarization and its Effects on Children's Diet, Health, and Growth among Rendille of Northern Kenya. Human Ecology, 32(5):531-59.

Harvey, P., Proudlock, K. et al. (2010). Food Aid and Food Assistance in Emergency and Transitional Contexts: A Review of Current Thinking. London: Humanitarian Policy Group, ODI. Retrieved 28 April 2016, from http://www.odi.org/resources/docs/6038.pdf

Harvey, P. and Bailey, S. (2011). Cash Transfer Programming in Emergencies. London: Humanitarian Practice Network, ODI. Retrieved 28 April 2016, from http://odihpn.org/resources/cash-transfer-programming-in-emergencies/ 
Helland, J. (1998). Institutional Erosion in the Drylands: Case of the Borana Pastoralists. Eastern Africa Social Science Research Review, 14(2):49-72.

Hesse, C. and MacGregor, J. (2006). Pastoralism: Drylands' Invisible Asset? Issue Paper 142. London: International Institute for Environment and Development (IIED). Retrieved 28 April 2016, from http://pubs.iied.org/pdfs/12534IIED.pdf

Hesse, C. and Pattison, J. (2013). Ensuring Devolution Supports Adaptation and Climate Resilient Growth in Kenya. London: IIED. Retrieved 28 April 2016, from http://pubs.iied.org/17161IIED.html

Hesse, C. and Thébaud, B. (2006). Will Pastoral Legislation Disempower Pastoralists in the Sahel? Indigenous Affairs. 1(6):14-23.

Krätli, S. (2009). ABEK (Alternative Basic Education for Karamoja): Strategic Review. Kampala: Save the Children in Uganda.

Krätli, S., Kaufmann, B. et al. (2015). A House Full of Trap Doors: Identifying Barriers to Resilient Drylands in the Toolbox of Pastoral Development. London: IIED. Retrieved 28 April 2016, from http://pubs.iied.org/pdfs/10112IIED.pdf

Levine, S. (2008). Trigger Happy? Why we need to rethink the signals which determine humanitarian intervention for more timely response. Washington, D.C.: USAID. Retrieved 28 April 2016, from

http://www.fao.org/fileadmin/user_upload/drought/docs/trigger\%20happy\%2012\%2011\%200 8\%20FINAL.pdf

Levine, S. (2010). An Unromantic Look at Pastoralism in Karamoja: How Hard-Hearted Economics Shows That Pastoral Systems Remain the Solution, and Not the Problem. Nomadic Peoples. 14(2):147-53.

London School of Hygiene and Tropical Medicine (LSHTM). (2013). The Humanitarian Health Evidence Review. London: LSHTM.

Manley, J., Gitter, S. and Slavchevska, V. (2011). How Effective are Cash Transfer Programs at Improving Nutritional Status. World Development, 48:133-155. Retrieved 28 April 2016, from

https://www.researchgate.net/publication/228420737_How_Effective_are_Cash_Transfer_Pr ograms_at_Improving_Nutritional_Status

Markakis, J. (2004). Pastoralism on the Margin. London: Minority Rights Group International.

Maxwell, D., Majid, N. et al. (2014). Lessons Learned from the Somalia Famine and the Greater Horn of Africa Crisis 2011-2012: Desk Review of Literature. Medford, Massachusetts: Feinstein International Center, Tufts University. Retrieved 28 April 2016, from http://www.alnap.org/resource/12736

McPeak, J., Little, P.D. and Doss, C.R. (2012). Risk and Social Change in an African Rural Economy: Livelihoods in pastoralist communities. Abingdon, Oxon: Routledge.

Merten, S. and Haller, T. (2009). Whose Logic? The Local Redistribution of Food Aid Targeting Old and Chronically Sick People in Zambia. Human Organization 68 (1): 89-102.

Moris, J.R. (1988). Oxfam's Kenya Restocking Projects. Oxford: Oxfam.

Mkutu, K. (2001). Pastoralism and Conflict in the Horn of Africa: Report. Nairobi: Africa Peace Forum.

Morton, J. (2006). Pastoralist Coping Strategies and Emergency Livestock Market Intervention. In McPeak, J.G and Little, P.D. (eds), Pastoral Livestock Marketing in Eastern Africa: Research and Policy Challenges. ITDG Publishing, Warwickshire, pp. 227-46. 
Oba, G. (1992). Ecological Factors in Land Use Conflicts, Land Administration and Food Security in Turkana, Kenya. London: Overseas Development Institute.

Parkinson, J. (2009). A Review of the Evidence Base for WASH Interventions in Emergency Responses. Oxfam/UNICEF Wash Cluster. http://washcluster.net/wpcontent/uploads/sites/5/2014/04/GWC-Review-on-the-Evidence-Base-for-WASHinterventions-in-Emergency-Responses-200109.pdf

Rose, D. (2012). Assessing Food Security at WFP: Towards a Unified Approach. Geneva: World Food Programme. Retrieved 19 September 2016, from https://resources.vam.wfp.org/sites/default/files/WFP\%20Fd\%20Sec\%20Assessment_Desig n\%20Phase\%201\%20Report.pdf

Salzman P. (ed.) (1980). When Nomads Settle: Processes of Sedentarization as Adaptation and Response. New York: Praeger.

Scoones, I. (1998). Sustainable Rural Livelihoods: A Framework for Analysis. Brighton, Sussex: Institute of Development Studies. Retrieved 28 April 2016, from https://www.ids.ac.uk/publication/sustainable-rural-livelihoods-a-framework-for-analysis

Sharp, K. (1999). Food Aid Targeting in East Africa. Nairobi: FEWS Project.

Smith, G., MacAuslan, I. et al. (2011). New Technologies in Cash Transfer Programming and Humanitarian Assistance. Oxford: Cash Learning Partnership (CaLP). Retrieved 28 April 2016, from http://cashlearning.org/resources/library/272-new-technologies-in-cash-transferprogramming-and-humanitarian-assistance

Spangaro, J., Zwi, A.B. et al. (2013). What is the Evidence of the Impact of Initiatives to Reduce Risk and Incidence of Sexual Violence in Conflict and Post-Conflict Zones and Other Humanitarian Crises in Lower and Middle Income Countries? London: Institute of Education, University of London. Retrieved 28 April 2016, from http://eppi.ioe.ac.uk/cms/LinkClick.aspx?fileticket=Q-Whllmx17U\%3d

Turnbull, C. (1974). The Mountain People. London: Pan Books.

Department for International Development (DFID). (2014). Assessing the Strength of Evidence. London: DFID. Retrieved 13 July 2016, from https://www.gov.uk/government/uploads/system/uploads/attachment_data/file/291982/HTNstrength-evidence-march2014.pdf

Vu, A., Atif, A. et al. (2014). The Prevalence of Sexual Violence Among Female Refugees in Complex Humanitarian Emergencies: A Systematic Review and Meta-Analysis. Public Library of Science Currents 6. Retrieved 28 April 2016, from http://currents.plos.org/disasters/article/the-prevalence-of-sexual-violence-among-femalerefugees-in-complex-humanitarian-emergencies-a-systematic-review-and-meta-analysis/

World Food Programme (WFP). (n.d.) Food Assistance for Assets. Retrieved 27 January 2016, from https://www.wfp.org/food-assets 
Published by Oxfam GB under ISBN 978-0-85598-876-0 in January 2017.

Oxfam GB, Oxfam House, John Smith Drive, Cowley, Oxford, OX4 2JY, UK.

\section{OXFAM}

Oxfam is an international confederation of 20 organizations networked together in more than 90 countries, as part of a global movement for change, to build a future free from the injustice of poverty. Please write to any of the agencies for further information, or visit www.oxfam.org. 